\title{
CELLULAR EFFECTS OF GLIOTOXIN \\ EVALUATION OF A PROTEOMIC, ISOTOPE-BASED METHOD TO DETECT REACTIVE CYSTEINES
}

BY

SVEN SONDHAUSS

\begin{abstract}
A thesis
submitted to the Victoria University of Wellington in fulfilment of the requirements for the degree of Master of Science
\end{abstract}

Victoria University of Wellington 2014 


\section{ACKNOWLEDGEMENTS}

My first and foremost thanks and acknowledgements deserves no one less than my supervisor Dr. Bill Jordan. I am very thankful for the opportunity to work with him and on this project. This thesis could not have been completed without his guidance and willingness to help.

I also like to thank Jonathan Dunne for listening to my sheer endless questions and his patient in answering them. His help and technical expertise was a vital support for this thesis.

Next, I would like to thank the Malaghan Institute of Medical Research in person of Kylie Price for allowing me to use their flow cytometer and for the technical and methodical help in performing my experiments.

Another great thanks goes to Sarah Cordiner and Bhumika Bhatt, who showed me many laboratory techniques and did their best to help me.

I would like to thank my family, especially my parents for their support and assistance. Even though I'm far away from home, they provided me with the necessary help and motivation.

I wouldn't be here if it wasn't for my girlfriend Maren. She convinced me to go with her to New Zealand, a decision which I haven't regretted. Her support and motivation were as important for this thesis as all the help from the people mentioned above.

Thank you! 


\section{ABSTRACT}

Cysteinyl residues in proteins are important for many cellular processes and unregulated modification of the cysteine thiol group can have negative effects on cell vitality and viability. In this thesis, the potential for use of the isotope coded affinity tag (ICAT) method for detection of cysteine modification has been investigated. ICAT reagents label free cysteine thiols. The aim of this study was to use HL-6o cells treated with gliotoxin, a fungal metabolite with a reactive disulfide bridge, as a system to evaluate the performance of ICAT for identification of cysteine modification in a whole cell proteome. Gliotoxin has antimicrobial, antitumor, immunosuppressive and cytotoxic properties that have been related to cysteine modification in proteins. Cellular assays including viability using 3-(4,5-dimethylthiazol-2-yl)-2,5-diphenyltetrazolium bromide, cell cycle analysis, and measurement of reactive oxygen species using dichlorofluorescin diacetate were used to establish conditions for measuring the effects of gliotoxin on HL-60 cells prior to large-scale cellular damage. Cells exposed to gliotoxin and control cells were then labeled with ICAT reagents and analysed by offline reversed phase liquid chromatography followed by matrix-assisted laser desorption/ionization tandem mass spectrometry. The pilot results identified tubulin, glyceraldehyde-3-phosphate dehydrogenase and peptidyl-prolyl cis-trans isomerase as putative targets of gliotoxin. Additionally, this study showed that ICAT can be used to detect modified cysteines from a highly complex sample, but further optimization is needed to unlock the full potential for detection of cysteine modification in complex samples. 


\section{ABBREVATIONS}

ACN

ADH

BSA

CHCA

CK

cys

DAPI

DCFDA

DMEM

DMSO

DTT

ETP

FCS

FDR

FTase

GRx

GSH

GSSG

GTX

ICAT

LC

MALDI

MS

MS/MS

MTT

NF-kB

PBS

RNS

ROS

RP-LC

RPMI

SDS

TFA acetonitrile

alcohol dehydrogenase

bovine serum albumin

a-cyano-4-hydroxycinnamic acid

creatin kinase

cysteine/cysteines

4',6-diamidino-2-phenylindole

2',7'-Dichlorofluorescin diacetate

Dulbecco's Modified Eagle Medium

dimethyl sulfoxide

dithiothreitol

epipolythiodioxopiperazine

fetal calf serum

false discovery rate

farnesyltransferase

glutaredoxin

glutathione

Glutathione disulfide

gliotoxin

isotope coded affinity tag

liquide chromatografie

matrix-assisted laser desorption/ionization

mass spectrometer/spectrometry

tandem mass spectrometry

3-(4,5-dimethylthiazol-2-yl)-2,5-diphenyltetrazolium bromide

nuclear factor-kB

phosphate buffered solution

reactive nitrogen species

reactive oxygen species

reversed phase liquid chromatography

Roswell Park Memorial Institute medium

sodium dodecyl sulfate

trifluoroacetic acid 


\section{TABLE OF CONTENTS}

ACKNOWLEDGEMENTS ii

ABSTRACT iii

ABBREVATIONS iv

1 Introduction 9

1.1 Structure and biosynthesis of gliotoxin 9

$\begin{array}{lll}1.2 & \text { Toxic effects of gliotoxin on mammalian cells } & 10\end{array}$

1.3 Mechanism of GTX interaction with proteins 13

1.4 Hypothetical interactions of GTX 15

1.5 Use of ICAT mass spectrometry to detect cysteine modification 16

1.6 Aims of the study 19

2 Methods 20

$\begin{array}{lll}2.1 & \text { Cellular assays } & 20\end{array}$

$\begin{array}{lll}2.1 .1 & \text { Cell culture } 20\end{array}$

2.1.2 Determination of cell number 20

2.1.3 Cell viability/metabolism assay 20

2.1.4 Morphological assessment 21

2.1.5 Detection of reactive oxygen species 21

2.1.6 Cell cycle analysis 22

$\begin{array}{lll}2.2 & \text { Mass spectrometry } & 22\end{array}$

2.2.1 Cell treatment and preparation 22

2.2.2 Cell lysis and protein extraction 22

2.2.3 Protein quantification 23

2.2.4 ICAT labelling 23

2.2.5 Peptide purification 25

2.2.6 Direct spotting on a MALDI target 25

2.2.7 Liquid chromatography 26

2.2.8 Tandem mass spectrometry 26

2.2.9 One-dimensional gel electrophoresis 26

2.2.10 Data analysis 27 
3 Results 29

3.1 Cellular effects of GTX 29

3.1.1 Measurement of ROS production 31

3.1.2 Effects of GTX on cell morphology 31

3.1.3 Cell cycle analysis 32

3.2 ICAT Analysis of Protein Modification 33

3.2.1 ICAT labelling of BSA 33

3.2.2 ICAT analysis of the effects of GTX on HL6o cells 38

3.2.3 Comparison of all ICAT experiments 49

4 Discussion $\quad 58$

4.1 Cellular effects of GTX 58

4.1.1 Cell viability 58

$\begin{array}{lll}\text { 4.1.2 ROS production } & 58\end{array}$

4.1.3 Cell cycle analysis 59

4.1.4 Summary 59

4.2 ICAT-labelling of BSA 59

4.2.1 ICAT mass spectrometry of HL-60 cell extracts 60

$\begin{array}{lll}\text { 4.2.2 ICAT performance } & 64\end{array}$

4.2.3 Summary 64

$\begin{array}{ll}\text { REFERENCES } & 66\end{array}$

$\begin{array}{ll}\text { APPENDICES } & 73\end{array}$ 


\section{TABLE OF FIGURES}

Figure 1: Structure of gliotoxin. $\quad 10$

Figure 2: Proposed model of sporidesmin as an inactivator of GRx. 14

Figure 3: Theoretical interaction between GTX and CK. 15

Figure 4: Proposed interaction of GTX with ADH. $\quad 15$

Figure 5: Hypothetical reactions of GTX. 16

Figure 6: Flowchart of the ICAT processing method. 17

$\begin{array}{ll}\text { Figure 7: ICAT reagent structure. } & 18\end{array}$

Figure 8: Effects of cell number on MTT assay. $\quad 29$

Figure 9: Concentration-dependent effects of GTX on HL-60 cell metabolism. 30

Figure 10: Short-term effects of GTX on HL60 cell metabolism. 30

Figure 11: Effects of GTX on ROS production. 31

Figure 12: Mophology of HL-60 cells after various treatments. 32

Figure 13: Cell cycle analysis of treated and untreated HL-60 cells. 33

Figure 14: Comparison of protein coverage of the two BSA samples. 34

Figure 15: MS and MS/MS of an ICAT pair of the peptide CCTESLVNR. 37

Figure 16: 1D gel of treated cells and trypsin digest. 39

Figure 17: MS of ICAT labelled peptides from Experiment One. $\quad 40$

Figure 18: UV trace of the RP separation of peptides from Experiment One. 41

Figure 19: 1D electrophoresis of treated cells and trypsin digest. $\quad 42$

Figure 20: MS spectra of ICAT labelled peptides from Experiment 2a. 43

Figure 21: UV trace of the RP separation of peptides from Experiment 2a. 43

Figure 22: UV trace of the RP separation of peptides from Experiment 2b. 47

Figure 23: MS spectra of ICAT labelled peptides from Experiment 2b. 47 


\section{LIST OF TABLES}

Table 1: Theoretical cys-containing tryptic peptides of BSA.

Table 2: Overview of the ICAT experiments.

Table 3: List of identified proteins from Experiment One.

Table 4: List of identified proteins from Experiment 2a.

Table 5: List of identified proteins from Experiment 2b.

Table 6: List of MS ions from identified peptides of the different experiments.

Table 7: Comparative table of precursor masses from Exp. 2 a.

Table 8: Comparative table of precursor masses from Experiment $2 \mathrm{~b}$. 


\section{Introduction}

Plants, fungi and microbes produce a large variety of small molecules including those secreted as toxins that can affect a range of cellular processes such as transcription, development and intercellular communication. These secondary metabolites are often of therapeutic interest as they can be used directly or as lead compounds for new drugs. One well-known secondary metabolite is penicillin, a potent antibiotic agent. The fungal metabolite gliotoxin (GTX) was discovered soon after penicillin and has a wide range of effects.

GTX was first isolated in 1936 from Trichoderma sp. (previously named Gliocladium fimbriatum; Weindling and Emerson, 1936). Subsequently gliotoxin was found in other fungi including Aspergillus fumigatus, Aspergillus chevalieri, Penicillum obscurum and Trichderma viride (Brian and Hemming, 1945; Wilkinson and Spilsbury, 1965).

Gliotoxin is a member of the epipolythiodioxopiperazine (ETP) class of molecules. This class consists of at least 14 members and is characterized by a disulfide bridged diketopiperazine ring (Gardiner, Waring and Howlett, 2005). The sulfur-bridged ring is essential for the effects of ETPs on cells, bacteria and viruses (Okamoto et al., 1986) and chemical modification of the sulfurs leads to complete loss of biological activity.

GTX has antibacterial, antifungal, antitumor, antiviral and immunosuppressive properties and inhibits mammalian cell proliferation (Jordan and Cordiner, 1987; Gardiner, Waring and Howlett, 2005). The exact mechanism of action is unknown but there are two main hypotheses (Jordan and Cordiner, 1987): (1) the ETP sulfurs bind covalently to cysteine sulfurs in proteins forming mixed disulfides that may affect the activity of modified proteins (Srinivasan et al., 2006), and/or (2) by cycling between the oxidized and reduced forms of ETPs with generation of the reactive oxygen species superoxide, hydrogen peroxide and hydroxyl radical (Munday, 1982).

\subsection{Structure and biosynthesis of gliotoxin}

The secondary metabolite gliotoxin contains the typical ETP sulfur-bridged diketopiperazine (Fig. 1). Biosynthesis of GTX starts with two amino acids, phenylalanine and serine (Suhadolnik and Chenoweth, 1958; Gardiner and Howlett, 2005). The discovery 


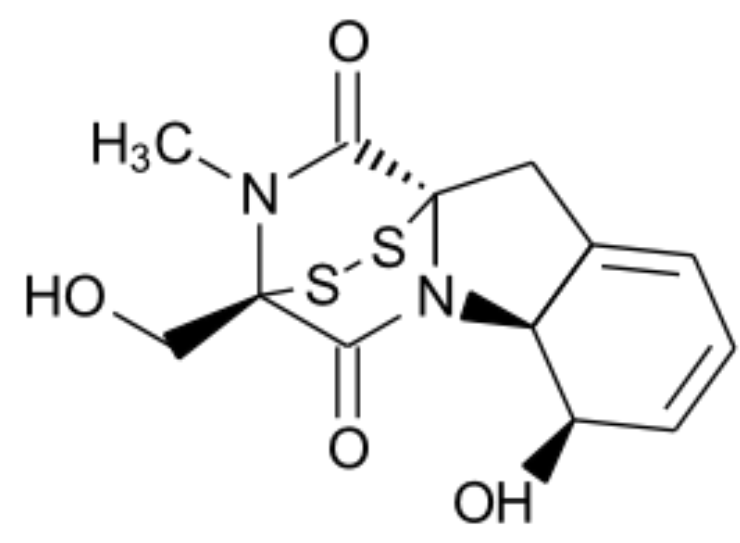

Figure 1: Structure of gliotoxin.

of a gene cluster related to the biosynthesis of another ETP sirodesmin in Leptosphaeria maculans allowed the prediction of a similar cluster for gliotoxin in Aspergillus fumigatus (Gardiner et al., 2004; Gardiner and Howlett, 2005). This cluster consists of 12 different genes (gli genes): gliA, glic, gliF, gliG, glil-K, gliM, gliN, gliP, gliT and gliz (Gardiner and Howlett, 2005). The predicted biosynthetic pathway starts with serine and phenylalanine which are condensed by a non-ribosomal peptide synthetase (GliP) producing the diketopiperazine cyclo-(L-phenylalanyl-L-seryl) core (Gardiner and Howlett, 2005; Fox and Howlett, 2008). A cytochrome P450 oxidoreductase (Glic) activates the core prior to addition of glutathione by a glutathione S-tranferase (GliG), yielding a bis(glutathione) adduct (Scharf et al., 2011; Chang et al., 2013). A dipeptidase (GliJ) and a thioesterase (Glii) cleave the glutathione residues leaving two thiol groups. Subsequently, a methyl transferase (GliN) adds a methyl group to the molecule and one of the cytochrome P450 monooxogenases (GliC or GliF) closes the ring between the benzyl and the diketopiperazine ring. Finally, a thioredoxin reductase leads to the formation of the disulfide bond. Most of the genes are regulated by a zinc-finger transcription factor (Gliz) and the product gets transported out of the cell by a major facilitator type transporter (GliA; Bok et al., 2006; Scharf et al., 2010). Two proteins, GliT and GliK, protect the fungi against the toxin (Scharf et al., 2010; Schrettl et al., 2010; Gallagher et al., 2012).

\subsection{Toxic effects of gliotoxin on mammalian cells}

Many cellular effects of GTX have been investigated since its discovery, but there are very few instances in which the specific molecular interactions of GTX are described. There are a variety of actions on cultured mammalian cells including apoptotic cell death (Peterson et al., 2010; Witko-Sarsat et al., 2010; Speth et al., 2011; Tartakovsky et al., 2012; Hubmann et al., 2013) and depletion of mature lymphocytes (Mullbacher et al., 1988). GTX caused $50 \%$ cell loss at $0.5 \mu \mathrm{M}$ and $0.03 \mu \mathrm{M}$ respectively in A549 (human lung 
carcinoma epithelia cell line) and NR8383 (rat alveolar macrophage cell line) cells. GTX induced apoptosis in cultured hepatic stellate cells at $1.5 \mu \mathrm{M}$, and in hepatic stellate cells in mice dosed at $3 \mathrm{mg} / \mathrm{kg}$ (Hartland et al., 2009; Shen et al., 2011). The cytotoxicity in hepatic stellate cells may be due to increased mitochondria permeability resulting in cytochrome c release and activation of caspase-3 (Wright et al., 2001; Kweon et al., 2003). Shortly after GTX treatment, the cells showed an induced activity of caspase 3 and DNA fragmentation (DNA laddering), characteristic for apoptosis (Arends, Morris and Wyllie, 1990). Rat hepatocytes were only affected at a 10 to 100 -fold higher concentration of GTX and showed necrosis (Wright et al., 2001).

The nuclear factor NF-kappa B (NF-kB) seems to play a role in immunosuppression and apoptosis induced by GTX. GTX inhibits activation of NF-kB in many, but not all, cells (Wright et al., 2001; Cho et al., 2009; Trebec-Reynolds et al., 2010; Rashmi et al., 2011). Normally, NF-KB is activated by phosphorylation and ubiquitination following degradation of the physiological inhibitor IkB-a (Henkel et al., 1993; Traenckner, Wilk and Baeuerle, 1994; Napetschnig and Wu, 2013). These post translational modifications expose the nuclear localization signal of NF-kB, allowing it to enter the nucleus and bind to DNA. Inhibition of NF-kB activation by GTX is suggested to be due to decreased degradation of IKB- $\alpha$ by blocking the proteolytic activity of the proteasome (Pahl et al., 1996b; Kroll et al., 1999). GTX targets the $20 \mathrm{~S}$ subunit of the proteasome, and $10 \mathrm{mM}$ dithiothreitol (DTT) could fully restore the function of the proteasome. This suggests that GTX covalently binds to or near the active site of the $20 \mathrm{~S}$ subunit. NF-kB has important roles in immune and inflammatory processes (Napetschnig and $\mathrm{Wu}, 2013$ ) and inhibition by GTX may account for at least some of the immunosuppressive properties of GTX (Pahl et al., 1996a).

Another target might be the mitochondrial permeability transition pore. This pore consists of the voltage-dependent anion channel, the adenine nucleotide translocase and a peptidyl-prolyl cis-trans isomerase cyclophilin $\mathrm{D}$ which is the target of the immunosuppressive cyclosporine A. This pore allows molecules smaller than $1500 \mathrm{Da}$ to pass under specific circumstances (Bernardi, 2013) and an increased permeability can lead to mitochondrial swelling and cell death via apoptosis or necrosis, depending on the conditions (Crompton, 1999). The specific condition for the mitochondrial permeability 
transition pore to open are oxidative stress, high levels of mitochondrial calcium and low levels of ATP (Bernardi, 2013). GTX causes calcium release from rat skeletal and liver mitochondria (Schweizer and Richter, 1994; Silva, Winterhalter and Richter, 1997) leading to the activation of the mitochondrial permeability transition pore and subsequently to apoptosis or necrosis. Supporting this hypotheses, a calcium chelator, quin-2-am, prevented DNA laddering in GTX-treated hepatic stellate cells (Wright et al., 2001). Additionally, a mitochondrial permeability transition pore inhibitor, tamoxifen, is also able to prevent DNA laddering (Wright et al., 2001). Also relevant is the activity of cyclosporin $A$ that binds to cyclophilin $D$ and prevents the mitochondrial permeability transition pore from opening. However in the presence of GTX cyclosporine A was unable to prevent DNA laddering caused by the opening of the mitochondrial permeability transition pore. Wright et al. (2001) suggested that GTX may bind to cyclophilin D or other mitochondrial permeability transition pore proteins and thereby blocks binding of cyclosporine A.

Some evidence also points to GTX as a NOTCH2 inhibitor (Hubmann et al., 2013). $\mathrm{NOTCH}_{2}$ is a receptor in the Notch signal transduction pathway which is linked to many processes, for example lineage specification and homeostasis (Artavanis-Tsakonas, Rand and Lake, 1999; Miele, 2006). The inhibition of NOTCH2 by GTX leads to apoptosis in chronic lymphocytic leukemia cells. In contrast, NF-kB is not inhibited in these cells and the GTX treatment leads to an up-regulation of NOTCH3 and NR4A1 (Hubmann et al., 2013). NR4A1 is involved in the negative selection of self-reactive lymphocytes and is induced by a broad range of apoptotic stimuli (Li et al., 2000).

GTX affects histones by facilitating phosphorylation of histone $\mathrm{H}_{3}$ in murine thymocytes treated with $1 \mu \mathrm{M}$ GTX, likely due to modification of protein kinase $A$ activity (Waring, 1997). The phosphorylation of histone $\mathrm{H} 3$ may then lead to DNA fragmentation and apoptosis. The treated cells were sensitive to micrococcal nuclease and DNase I digestion suggesting a relationship between histone $\mathrm{H}_{3}$ phosphorylation and DNA fragmentation. A protein kinase A inhibitor, genistein, prevented histone phosphorylation and apoptosis in GTX treated thymocytes. GTX has been shown to inhibit histone methyltransferase G9a, which introduces methylation on lysine 9 of 
histone H3 (Sun et al., 2012). An inhibition of G9a can lead to centrosome disruption chromosome instability (Kondo et al., 2008).

Another postulated mode of action of ETPs including GTX is production of reactive oxygen species (ROS) by reduction and reoxidation of the disulfide bridge. Bernardo et al. (2003) reported that GTX in its oxidized form rapidly enters cells and is reduced by cellular GSH to GTX dithiol which is cell-impermeant, leading to accumulation with an up to 1000 times increased intracellular concentration of GTX. It has been suggested that in the presence of an appropriate reductant such as reduced glutathione (GSH) ETP disulfides are reduced to dithiols which can auto-oxidize back to disulfides, converting oxygen $\left(\mathrm{O}_{2}\right)$ into superoxide radical $\left(\mathrm{O}_{2}{ }^{-}\right)$(Eichner et al., 1988; Waring and Beaver, 1996) that can give rise to other reactive oxygen species including hydrogen peroxide and hydroxyl radical. In some cells the cytotoxic effects of GTX seem to be dependent on ROS production (Zhou et al., 2000; Suen et al., 2001). In contrast, Yoshida, Abe and Tsunawaki (2000) reported that GTX protected against superoxide production in activated neutrophils.

Spleen cells treated with GTX showed genomic DNA indicative of oxidative stress (Braithwaite et al. 1987). Briefly, ROS introduces single-strand breaks in the DNA doublestrand. A plasmid can be present in three different forms: a covalently closed circular without any breaks, an open circular with a single-strand break and a linear form with a double-strand break. In the present of a suitable reductant GTX damaged cellular and plasmid DNA via superoxide production in a cell-free systems (Eichner et al., 1988). Plasmid DNA incubated with $0.3 \mathrm{mM}$ GTX and $0.2 \mathrm{mM}$ reductant (GSH or DTT) for $10 \mathrm{~min}$ resulted in a reduction of the covalently closed circular form to $14 \%$ and $17 \%$. The genomic DNA treated with $90 \mu \mathrm{M} \mathrm{GTX}$ and $3 \mathrm{mM} \mathrm{GSH}$ showed extensive laddering after $15 \mathrm{~min}$ incubation.

\subsection{Mechanism of GTX interaction with proteins}

Inhibition of the enzyme farnesyltransferase (FTase) by GTX was discovered in a screen for antibiotic activity. Partially purified human FTase was completely inhibited by 4 $\mu M$ GTX (IC50 1.1 $\mu M$ ). A GTX derivative in which the sulfurs were alkylated was much less active. Reducing conditions ( 4 mM DTT) were necessary for measurement of FTase, even 
in the absence of GTX (Vanderpyl et al., 1992). The prevalent oxidation state of GTX in this experiment was therefore reduced, suggesting that the dithio structure was involved for inhibition of FTase, which is in contrast to the antimicrobial activity requiring the disulfide (Cavallito, Bailey and Warner, 1946). FTases are involved in the Ras pathway and thereby important for cell survival and proliferation (Lane and Beese, 2006). An in vivo study confirmed GTX as an FTase inhibitor and showed antitumor effects on breast cancer cells (Vigushin et al., 2004). Human FTase contains two cysteinyl residues (327 and 341) that might be modified by direct interaction with GTX or by ROS

The enzyme glutaredoxin (GRx) is inhibited by GTX and other ETPs through binding to an active site cys, with consequent formation of a disulfide bridge between cys-25 and cys-82 (Srinivasan et al., 2006). The irreversible inactivation required oxygen, reduced GRx and oxidized GTX. Formation of the disulfide bond between cys- 25 and cys- 82 was dependent on the presence of oxygen (Fig. 2).

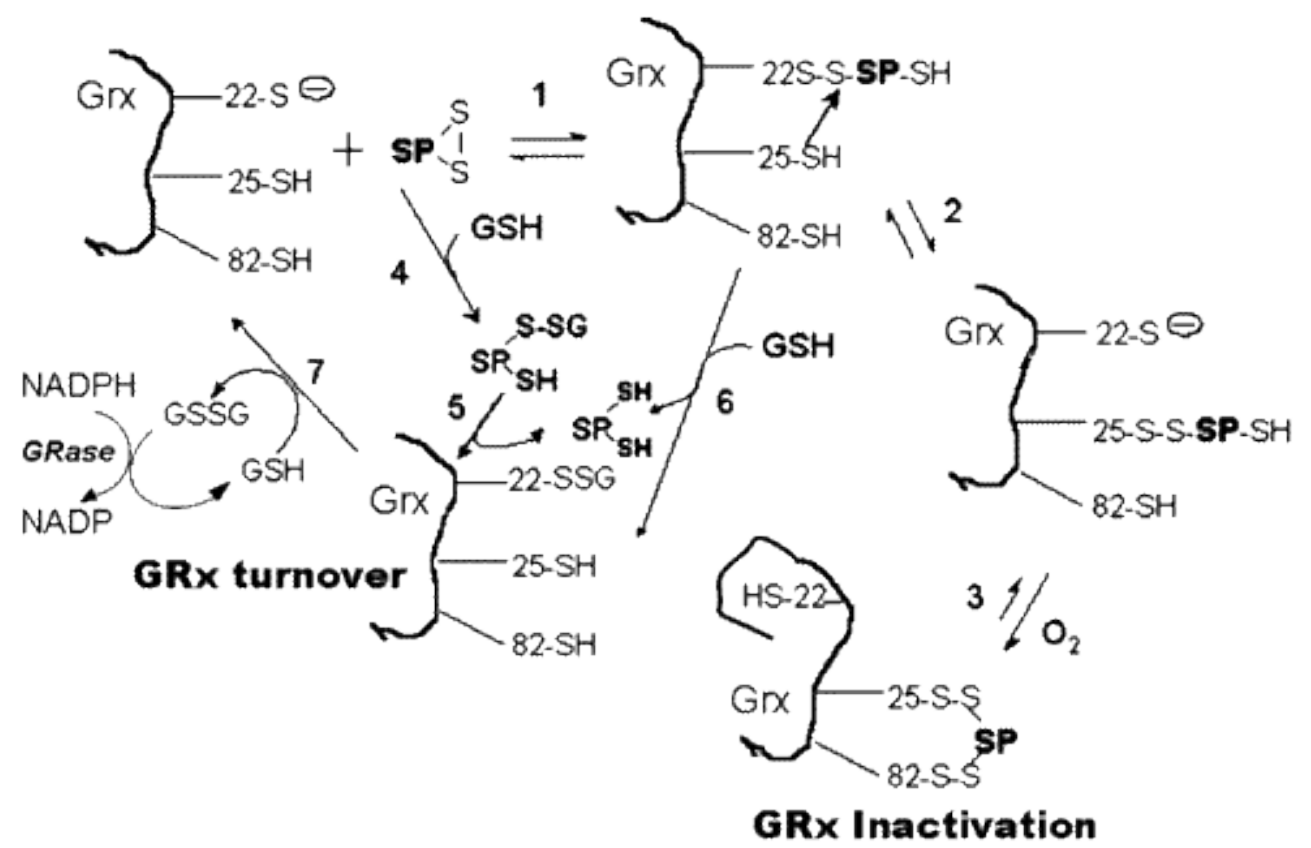

\footnotetext{
Figure 2: Proposed model of sporidesmin as an inactivator of GRx. Reprinted with permission from Biochemistry, 45, Usha Srinivasan, Aveenash Bala, Shu-chuan Jao, David W. Starke, T. William Jordan, John J. Mieyal, Selective inactivation of glutaredoxin by sporidesmin and other epidithiopiperazinediones. 8978-8987, Copyright (2006) American Chemical Society.
}

Creatine kinase (CK) is also inhibited by GTX. Reaction with $100 \mu \mathrm{M}$ GTX for $3 \mathrm{~h}$ resulted in a $50 \%$ loss of activity of CK (Hurne, Chai and Waring, 2000). Inactivation was reversed by addition of $10 \mu M$ DTT. CK contains four cysteinyl residues (73, 145, 253 and 282). It was suggested that GTX caused the formation of an internal disulfide between 
Cys-73 and Cys-282 that are in close proximity. Two of four cys residues (253 and 282) also contained covalently bond GTX after treatment with $10 \mu \mathrm{M}$ radiolabeled GTX (Fig. 3). CK may also be inactivated by ROS (Thomas, Carr and Winterbourn, 1994).

Alcohol dehydrogenase $(A D H)$ is also inhibited by GTX, with two suggested mechanisms: covalent modification or via free radical damage (Waring, Sjaarda and Lin, 1995). In the first mechanism, GTX binds to either cys 281 or cys 282 that are located in the binding pocket for the nucleotide cofactor (Niederhut et al., 2001). The bound GTX might block this pocket preventing the necessary cofactor to bind. Addition of a reductant did not reverse the inhibition but increased it. The other mechanism relies on the ability of GTX to generate superoxide causing oxidative damage to ADH. The generation of ROS requires reduction of GTX which may explain why a reductant increased the inhibition of ADH (Fig. 4).

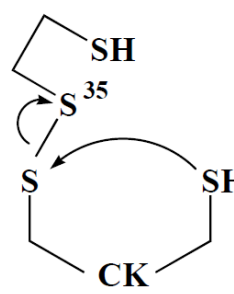

A

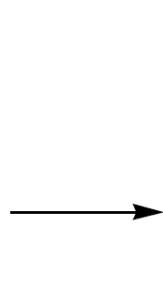

$\overbrace{\mathrm{SH}}^{\mathrm{SH}}$

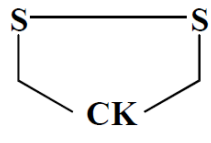

oxidized CK

B

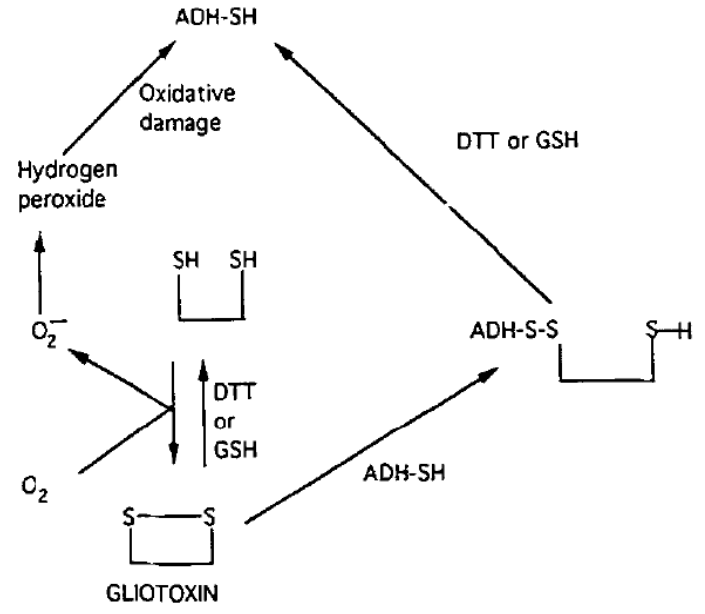

Figure 4: Proposed interaction of GTX with ADH. Reprinted from Biochemical Pharmacology, 49, Paul Waring, Allan Sjaarda, Qing H. Lin, Gliotoxin inactivates alcohol dehydrogenase by either covalent modification or free radical damage mediated by redox cycling, 11951201, Copyright (1995), with permission from Elsevier.

\subsection{Hypothetical interactions of GTX}

Based on the information presented above hypothetical pathways of GTX action can be proposed (Fig. 5). Oxidized GTX enters the cell and is subject to rapid reduction by GSH. The reduced GTX can either cycle back to its disulfide form and produce superoxide 


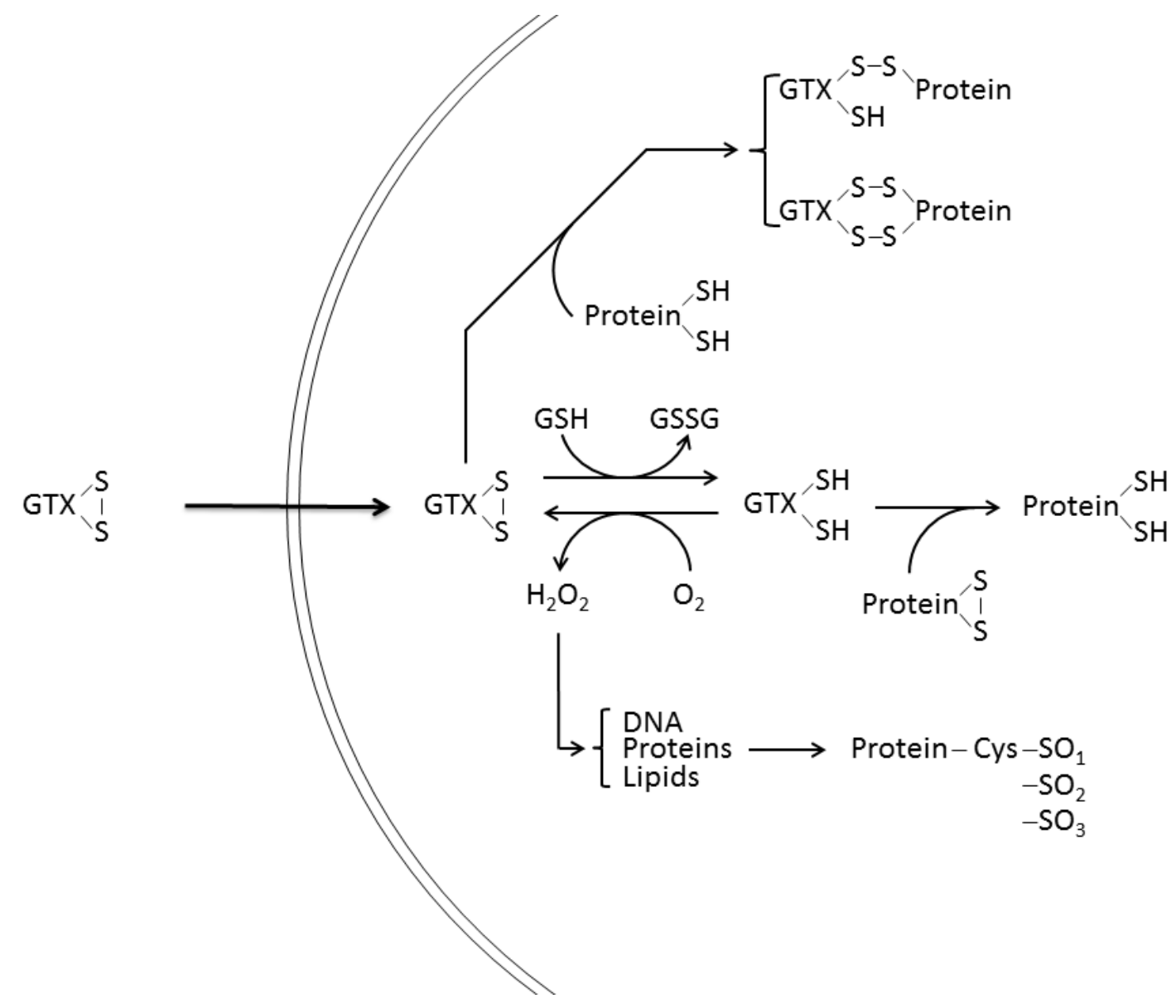

Figure 5: Hypothetical reactions of GTX.

or can interact with disulfide groups of proteins. Alternatively, oxidized GTX can also form disulfide bridges with protein cysteine thiols. Superoxide or other ROS could induce oxidative damage to DNA, lipids and proteins including oxidation of protein cysteines to sulfenic, sulfinic or sulfonic acids ( $\left.\mathrm{SO}_{1}, \mathrm{SO}_{2}, \mathrm{SO}_{3}\right)$.

\subsection{Use of ICAT mass spectrometry to detect cysteine modification}

GTX apparently has a wide range of biological activities and can potentially modify protein cysteines that are involved in many different processes including protein structure and cellular regulation. Modification of such cysteines can lead to misfolded proteins, deregulation of cellular processes and inhibition of enzymes (for an overview see Pace and Weerapana, 2013). Possible targets of GTX could therefore be identified by 
searching for modified cysteines. The isotope coded affinity tag (ICAT) process has potential to detect cysteine modification on a proteomewide scale. A modified ICAT process has been used to detect reactive cysteines of p21ras GTPase that are susceptible to modification by peroxynitrite and glutathione disulfide (Sethuraman et al., 2007), and redox sensitive thiols of protein disulfide isomerase (Kozarova et al., 2007). With the analysis of the membrane particulate fraction of the rabbit heart a more complex sample was analyzed using a modified ICAT approach (Sethuraman et al., 2004).

ICAT was developed as a method to

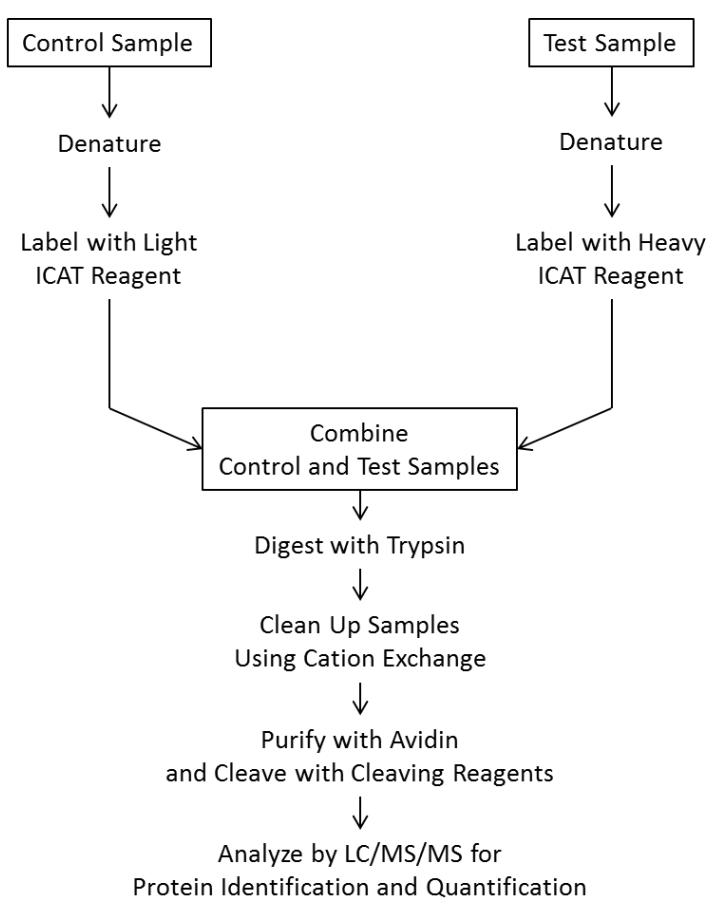

Figure 6: Flowchart of the ICAT processing method. quantify proteins from two different samples. The ICAT method uses two labelling reagents: 'ICAT light' reagent with ${ }^{12} \mathrm{C}$ and 'ICAT heavy' reagent with ${ }^{13} \mathrm{C}$. This isotope coding allows the differentiation of the two samples by mass spectrometry. ICAT reagents contain a biotin affinity tag, an acidic cleavable linker, $\mathrm{a}^{12} \mathrm{C}$ or ${ }^{13} \mathrm{C}$ isotope-coded tag, and a thiol-specific reactive group. The process begins with the incubation of the samples with the ICAT reagent. The reactive group of the ICAT reagent binds to accessible thiols of proteins (Fig. 6 ). ${ }^{12} \mathrm{C}$ - and ${ }^{13} \mathrm{C}$-ICAT labelled samples are then combined and digested to obtain peptides. In further processing, the biotin affinity tag allows specific retrieval of ICAT-labeled peptides from the mixture. The linker is cleavable to reduce the size from $907 \mathrm{Da}$ to $227 \mathrm{Da}$, or $916 \mathrm{Da}$ to $236 \mathrm{Da}$, of the light ICAT label and the heavy ICAT label respectively (Fig. 7). In the following MS analysis the differentially labeled peptides are detected with a 9 Da mass differences. The relative intensities of these 9 Da mass pairs allows calculation of the ratio of light to heavy labeled peptides.

The peptides can be further analyzed by tandem mass spectrometry (MS/MS) to acquire the peptide sequence and identify the protein. Collision-induced dissociation generates a fragment ion series which depends on the peptide sequence. 
ICAT requires free (reduced) cysteine thiols to label proteins. Modification of cysteines by GTX should therefore, in theory, be detectable using ICAT. Most simply, proteins that have cysteines modified by direct or oxidative interaction with GTX should show loss of ICAT labeling. In order to preserve the GTX-induced modifications the initial reducing step prior to labeling with ICAT needs to be excluded.

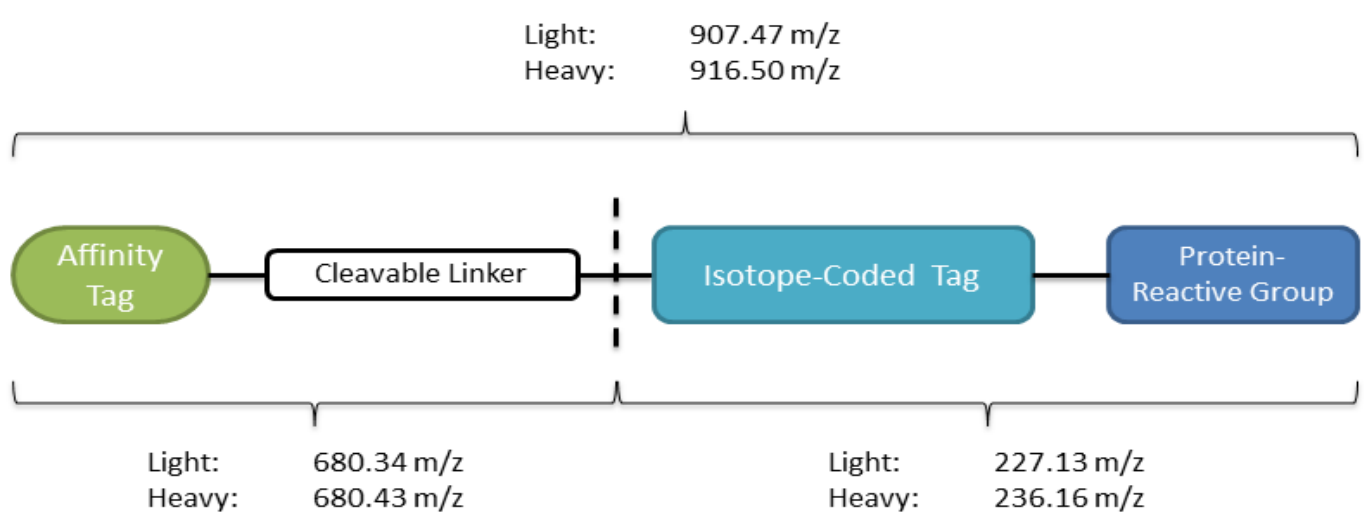

Figure 7: ICAT reagent structure with the masses of the whole reagent, the cleavable part and the remaining isotopecoded tag. 


\subsection{Aims of the study}

The goal of this study was to establish conditions for examination of protein modification using ICAT. Initially, cellular effects of GTX were examined using HL-60 cell cultures to define conditions where there might be protein change prior to substantial cytotoxicity including cell death. Assessment of cellular change was carried out using assays for cell viability, ROS production and cell cycling. Attention was given to the number of cells in each assay as the effects of gliotoxin and other ETPs on cultured cells are dependent on the amount of toxin per cell as well as the concentration of toxin in the culture medium (Cordiner and Jordan, 1983; Jordan and Cordiner, 1987).

ICAT labelling, without reduction of protein thiols, was then used to investigate the potential for detection of modified protein cysteines in extracts of the cultured cells. Workup of the ICAT-labelled proteins used a single one-step cleanup by ion exchange chromatography prior to capture of the biotin tagged proteins on an avidin column. Peptides were separated by reverse-phase liquid chromatography prior to MALDI MS and database searches were used to investigate whether modified cysteine containing peptides could be detected. 


\section{Methods}

GTX, molecular weight 326.39 from G. fimbriatum, was obtained from Sigma-Aldrich (Saint Louis, MO) with a purity of $98 \%$. The GTX was dissolved in dimethyl sulfoxide (DMSO) to obtain a stock solution with a concentration of $5 \mathrm{mg} / \mathrm{ml}$. Subsequent dilutions were made prior to the experiments.

\subsection{Cellular assays}

\subsubsection{Cell culture}

HL-60 (human promyelocytic leukemia) cells were cultured in DMEM (Dulbecco's Modified Eagle Medium, high glucose, HEPES, Gibco ${ }^{\circledR}$, NY, USA) or RPMI 1640 medium (Roswell Park Memorial Institute, Gibco ${ }^{\circledR}$ ) supplemented with $10 \%$ fetal calf serum (FCS) and 100 units $/ \mathrm{ml}$ of penicillin and streptomycin. The cells were maintained in a humidified atmosphere with $5 \% \mathrm{CO}_{2}$ at $37^{\circ} \mathrm{C}$. The cells were passage 1:10 or 1:5 when they reached approximately $80 \%$ visual confluency.

\subsubsection{Determination of cell number}

The cell number was determined using a haemocytometer and trypan blue $(0.4 \%$ solution; Sigma-Aldrich). Samples (10 $\mu$ l) of the HL-6o cell culture were combined 1:1 with the trypan blue solution. Ten microliters of this mixture was loaded on the haemocytometer and observed under a microscope. Cells which excluded the dye were considered as living cells and only those were considered for the cell number.

\subsubsection{Cell viability/metabolism assay}

The cytotoxic effects of gliotoxin on HL-6o cells were determined using an MTT (3(4,5-dimethylthiazol-2-yl)-2,5-diphenyltetrazolium bromide; Sigma-Aldrich) assay. In living, metabolically active cells, MTT is reduced to a purple formazan (Mosmann, 1983; Berridge, Herst and Tan, 2005).

The cells were seeded into a 96-well plate at $2 \times 10^{4}$ cells in $100 \mu$ per well. The cells were then treated with gliotoxin, DMSO (Sigma-Aldrich) or untreated for $24 \mathrm{~h}$ under cell 
culture conditions. After the treatment, $20 \mu \mathrm{l}$ of a MTT solution $(5 \mathrm{mg} / \mathrm{ml}$ in PBS; $137 \mathrm{mM}$ $\mathrm{NaCl}, 2.7 \mathrm{mM} \mathrm{KCl}, 4.3 \mathrm{mM} \mathrm{Na}_{2} \mathrm{HPO}_{4}, 1.5 \mathrm{mM} \mathrm{KH}_{2} \mathrm{PO}_{4}, \mathrm{pH} 7.4$ ) was added to each well and incubated for $2 \mathrm{~h}$ under the same conditions. To dissolve the formazane crystals, $100 \mu \mathrm{l}$ solubilizer (10\% (w/v) SDS, 45\% (v/v) dimethylformamide, $\mathrm{pH} 4.5)$ was added to each well and the plate was incubated overnight. The absorbance of each well was measured with a plate reader (2300 EnSpire ${ }^{\circledR}$ Multilabel Plate Reader, PerkinElmer, Waltham, MA) at $585 \mathrm{~nm}$. The results are expressed as the percentage metabolic activity of the DMSOtreated control.

\subsubsection{Morphological assessment}

The morphology of cells was assessed using a Leica DMI 4000B microscope (Leica Camera AG, Solms, Germany) equipped with a CRAIC QDI 302 microscope spectrophotometer (CRAIC Technologies, San Dimas, CA) controlled by CCD Image Capture software (DFx41AF02, CRAIC Technologies) to acquire pictures of the cells. The cells were cultured in a 24-well plate at a density of $1 \times 10^{5}$ cells in $500 \mu$ per well. The cells were treated for $24 \mathrm{~h}$ with various concentrations of GTX or with DMSO.

\subsubsection{Detection of reactive oxygen species}

2',7'-Dichlorofluorescin diacetate (DCFDA, Sigma-Aldrich) was used to measure production of reactive oxygen species (ROS) and/or reactive nitrogen species (RNS) in the cell upon gliotoxin treatment. DCFDA is cell permeable and can easily enter the cell. Once in the cell, it is deacetylated which makes it less cell permeable. In the presence of ROS/RNS DCDFA is oxidized to a fluorescent form. The fluorescence is correlated with the amount of ROS/RNS present (Wang and Joseph, 1999; Myhre et al., 2003).

DCFDA was dissolved in DMSO resulting in a stock solution of $10 \mathrm{mM}$. HL-60 cells were harvested, washed with PBS and resuspended in $100 \mu \mathrm{l}$ serum-free DMEM with 20 $\mu M$ DCFDA per $2 \times 10^{4}$ cells. The cells were incubated for $30 \mathrm{~min}$ at $37^{\circ} \mathrm{C}$. After the incubation, the cells were washed with PBS, resuspended in media with serum and seeded into a 96-well plate at $2 \times 10^{4}$ cells per well at a final volume of $100 \mu$ l. The fluorescence was measured with a plate reader (2300 EnSpire ${ }^{\circledR}$ Multilabel Plate Reader, PerkinElmer) in 'well area scanning' mode. This first measurement was taken as the 
baseline. The cells were sedimented by centrifugation at $300 \times \mathrm{g}$ and the media was replaced with fresh media. GTX was added to the wells and the fluorescence was measured with a plate reader over $2 \mathrm{~h}$ at $10 \mathrm{~min}$ intervals. The negative controls were no treatment or DMSO only. Exposure to hydrogen peroxide was used as a positive control.

\subsubsection{Cell cycle analysis}

A flow cytometric method was used to determine the effects of gliotoxin on the cell cycle. The DNA was stained with DAPI (4',6-diamidino-2-phenylindole, Sigma-Aldrich).

For each treatment, $2 \times 10^{6}$ cells were collected and incubated with DMSO, different concentrations of gliotoxin or no treatment for $24 \mathrm{~h}$ under cell culture conditions. The cells were then washed with PBS and resuspended in $0.5 \mathrm{ml}$ PBS. The resuspended cells were transferred into $4.5 \mathrm{ml} 70 \%$ ethanol while vortexing and stored at $-20{ }^{\circ} \mathrm{C}$ until use, but at least overnight. After fixation, the cells were washed with PBS and stained with 1 $\mathrm{ml}$ DAPI solution ( $1 \mu \mathrm{g} / \mathrm{ml}$ DAPI, 0.1\% Triton X-100 in PBS) for $30 \mathrm{~min}$. The stained cells were analysed using a BD LSR II flow cytometer (Becton Dickinson Biosciences, Franklin Lakes, NJ) with BD Cell Quest Pro software (v. 6.1.3).

\subsection{Mass spectrometry}

\subsubsection{Cell treatment and preparation}

For the mass spectrometry analysis, $9 \times 10^{6}$ cells were cultured in $75 \mathrm{~cm}^{2}$ flasks in $20 \mathrm{ml}$ DMEM with GTX, DMSO as control, or untreated, for $3 \mathrm{~h}$. Cells were then washed three times with nitrogen-flushed PBS. To the last wash, protease inhibitor (cOmplete mini protease inhibitor cocktail, Roche Diagnostics, Mannheim, Germany; 1 tablet per 10 $\mathrm{ml}$ ) was added. The cells were centrifuged at $300 \mathrm{xg}$ in a tabletop centrifuge (MiniSpin ${ }^{\circledR}$, Eppendorf AG, Hamburg, Germany) for $5 \mathrm{~min}$ and the supernatant was completely removed. The cell pellets were kept at $-20^{\circ} \mathrm{C}$ until used.

\subsubsection{Cell lysis and protein extraction}

The cell pellets were resuspended in $500 \mu \mathrm{l}$ PBS with protease inhibitor and transferred to $2 \mathrm{ml}$ tubes. The cells were homogenized using a Polytron ${ }^{\circledR}$ PT1200 
(Kinematica AG, Lucerne, Switzerland) at full speed for $45 \mathrm{sec}$ on ice and were centrifuged for $30 \mathrm{~min}$ at $16100 \mathrm{x}$ g. Four volumes of Precipitation Agent $(29 \mathrm{ml}$ Precipitant 1, 1.7 ml Precipitant 2, 1.7 ml Precipitant 3, $1.7 \mathrm{ml}$ Precipitant 4; ProteoExtract ${ }^{\circledR}$ Protein Precipitation Kit (Calbiochem, Merck KGaA, Darmstadt, Germany) was added to the supernatants and then incubated at $-20{ }^{\circ} \mathrm{C}$ for $1 \mathrm{~h}$. After centrifugation for $10 \mathrm{~min}$ at $16100 \mathrm{xg}$, the pellets were washed two times by adding $500 \mu \mathrm{l}$ cold Wash Solution (ProteoExtract ${ }^{\circledR}$ Protein Precipitation Kit, Calbiochem), vortexing and centrifuging for $2 \mathrm{~min}$ at $14000 \mathrm{x}$ g. Each pellet was dried at room temperature for $30 \mathrm{~min}$ with the tube left open and then stored at $-20^{\circ} \mathrm{C}$ until used.

\subsubsection{Protein quantification}

The protein pellets were resuspended in $40 \mu$ l Denaturing Buffer (Cleavable ICAT ${ }^{\mathrm{TM}}$ Kit; Applied Biosystems, Foster City, CA). Two microliters of the resuspended sample were processed along with BSA samples (2-D Quant Kit, GE Healthcare, Uppsala, Sweden) for a standard curve (10 $\mu \mathrm{g}, 20 \mu \mathrm{g}, 30 \mu \mathrm{g}$ and $40 \mu \mathrm{g}$ BSA). To all samples, $500 \mu \mathrm{l}$ Precipitant (2-D Quant Kit, GE Healthcare) was added and incubated for 3 min at room temperature. After the incubation $500 \mu \mathrm{l}$ Co-Precipitant (2-D Quant Kit, GE Healthcare) was added to the samples and briefly vortexed. The samples were centrifuged for $5 \mathrm{~min}$ at $14000 \mathrm{x}$ g. The supernatant was removed and $100 \mu \mathrm{l}$ Copper Solution (2-D Quant Kit, GE Healthcare) and $400 \mu \mathrm{l} \mathrm{High-Q}$ water was added to the samples. The sample was vortexed to dissolve the pellet. To each sample $1 \mathrm{ml}$ working color reagent (100:1 Color Reagent A with Color Reagent B; 2-D Quant Kit, GE Healthcare) was added and mixed by inversion. The sample was incubated for $20 \mathrm{~min}$ at room temperature. Aliquots $(200 \mu \mathrm{l})$ from each sample and the standard curve were transferred to 96-well plate. The absorbance at $480 \mathrm{~nm}$ was measured in a plate reader using $200 \mu \mathrm{l} \mathrm{High-Q}$ water as the blank.

\subsubsection{ICAT labelling}

Initially, BSA was labelled with ICAT reagents (heavy and light; Cleavable ICAT ${ }^{\mathrm{TM}} \mathrm{Kit}$ ) at a 1:1 ratio as a proof of concept, and subsequently at a 1:4 ratio to evaluate the quantitation. 
For the GTX experiments three sets of cell samples were analysed. In the first set proteins from cells treated with GTX were labelled with the ICAT reagent heavy and proteins from cells treated with DMSO were labelled with ICAT reagent light. The second set was a repetition of the first set with optimization of the LC and MS methods. In the third set proteins from untreated cells were labelled with ICAT reagent heavy and light regents as a control. In all cell samples the combination ratio of heavy and light reagents was 1:1. The cation exchange step was used for sample cleanup only and not for sample fractionation. Peptides eluted from a $0.2 \mathrm{ml}$ cation exchange column were then subject to affinity purification on a $0.2 \mathrm{ml}$ avidin cartridge to capture the biotin labelled cyscontaining peptides. Two fractions were collected from the avidin column - an eluate (flowthrough) of unlabelled peptides that should not contain reactive cys residues, and an eluate of the labelled cys-containing peptides.

One hundred microgram of protein (BSA or extracted cell proteins) was dissolved in $80 \mu \mathrm{l}$ denaturing buffer for each labelling. To each tube of BSA, $2 \mu$ l reducing reagent was added and the mixtures were heated at $100{ }^{\circ} \mathrm{C}$ for $10 \mathrm{~min}$. The cell extracts, however, were not reduced. Each sample, BSA or cell extract, was added to one unit of cleavable ICAT reagent light (Cleavable ICAT ${ }^{\mathrm{TM}} \mathrm{Kit}$ ) and the other BSA or treated cell sample was added to one unit of cleavable ICAT reagent heavy (Cleavable ICAT ${ }^{\mathrm{TM}} \mathrm{Kit}$ ). The ICAT reagents were dissolved in $20 \mu \mathrm{l}$ acetonitrile each before the samples were added. The mixtures were incubated for $2 \mathrm{~h}$ at $37{ }^{\circ} \mathrm{C}$. The samples were combined by adding the content of the light reaction to the heavy reaction. The content of one vial trypsin from the ICAT Kit was dissolved in $200 \mu \mathrm{l}$ distilled water and added to the combined samples. The digest was incubated for $16 \mathrm{~h}$ at $37{ }^{\circ} \mathrm{C}$. The $\mathrm{pH}$ of the solution was adjusted to 2.5 to 3.3 by adding Cation Exchange Buffer - Load and the samples were loaded on the cation exchange cartridge, washed with $1 \mathrm{ml}$ Cation Exchange Buffer - Load and eluted by injecting $500 \mu \mathrm{l}$ Cation Exchange Buffer - Elute. The labelled peptides were purified using an avidin cartridge, while the unlabelled peptides were washed of the cartridge (flow through). The eluted peptides from the cation cartridge were combined with Affinity Buffer - Load, dried in a centrifugal vacuum concentrator (Labconco Centrivap concentrator) and cleaved with $90 \mu \mathrm{l}$ Cleaving Reagent A and B (95:5 ratio, Cleavable 
ICAT ${ }^{\mathrm{TM}} \mathrm{Kit}$ ) for $2 \mathrm{~h}$ at $37{ }^{\circ} \mathrm{C}$. The cleaved peptides were dried in a centrifugal vacuum concentrator.

\subsubsection{Peptide purification}

The ICAT labelled and cleaved samples were purified and concentrated using pipette tips with a C-18 matrix (PerfectPure C-18 tip, Eppendorf). Each sample was resuspended in $10 \mu \mathrm{l} 0.1 \%$ trifluoroacetic acid (TFA). The pipette was set to $10 \mu \mathrm{l}$. A tip containing the $\mathrm{C}-18$ matrix was pre-wetted by aspirating and discarding the Pre-Wet Solution ( $50 \%$ acetonitrile $(A C N), 0.1 \%$ TFA) four times. Ten microliter aliquots of Equilibration/Wash Solution (0.1\% TFA) were aspirated and discarded four times. The sample was loaded by aspirating and expelling ten times, and then washed by aspirating and discarding $10 \mu \mathrm{l}$ Equilibration/Wash Solution five times. The sample was eluted into a fresh tube by aspirating and expelling $10 \mu$ Elution Solution ( $80 \% \mathrm{ACN}, 0.1 \%$ TFA) eight times.

\subsubsection{Direct spotting on a MALDI target}

Samples from the ICAT preparation, from either the cation exchange cleanup or from after the avidin purification were spotted directly on a MALDI target plate to monitor sample processing.

Matrix solution was prepared by adding $10 \mathrm{mg}$ a-cyano-4-hydroxycinnamic acid (CHCA; Sigma-Aldrich) to $1 \mathrm{ml} 50 \%$ ACN with 0.1\% TFA. The solution was vortexed for 45 sec and centrifuged for $10 \mathrm{~min}$ at $14000 \mathrm{xg}$ in a tabletop centrifuge. The supernatant $(800 \mu \mathrm{l})$ was transferred into a fresh $1.5 \mathrm{ml}$ tube. The sample $(1 \mu \mathrm{l})$ was combined with matrix at a ratio of 1:1 and 1:10. From the sample-matrix mixture, $1.5 \mu$ l was spotted on a MALDI target plate and dried overnight at room temperature. For internal calibration, the calibration mixture (ProteoMass ${ }^{\mathrm{TM}}$ Peptide \& Protein MALDI-MS Calibration Kit, Sigma) was resuspended in matrix and $1.5 \mu$ aliquots were spotted on the plate. 


\subsubsection{Liquid chromatography}

A Tempo LC MALDI Plate spotting system with a Chromolith RP-18e column was used for chromatography of the ICAT labelled peptides and to combine them with matrix ( $50 \% \mathrm{ACN}, 0.1 \%$ TFA; containing $10 \mathrm{mg} / \mathrm{ml} \mathrm{CHCA}$ ) and spot on a MALDI plate.

The purified samples were dissolved in $20 \mu \mathrm{LC}$ Reagent A ( $2 \%$ ACN, $0.1 \%$ TFA) and $7 \mu$ l were injected into the chromatograph. The LC program started at $98 \%$ Reagent $A$ and $2 \%$ Reagent B (98\% ACN, 0.1\% TFA). Over 40 min the percentage of Reagent B was increased to $80 \%$ while decreasing Reagent $A$. The flow table is shown in Appendix $A$. The eluted sample was combined with matrix (1:1 ratio for BSA and first cell sample, 1:5 ratio for second and third cell samples) and every $16 \mathrm{sec}$ the fraction was spotted on a MALDI target plate. After liquid chromatography a calibration mixture was spotted on the plate (see 'Direct spotting on a MALDI target') and the spots were dried on the plate overnight at room temperature.

\subsubsection{Tandem mass spectrometry}

The peptides were analysed using an AB SCIEX TOF/TOF ${ }^{\mathrm{TM}} 5800$ mass spectrometer (Applied Biosystems) controlled by TOF/TOF ${ }^{\mathrm{TM}}$ Series Explorer ${ }^{\mathrm{TM}}$ software V.4.1.0. The MS and MS/MS spectra were acquired using continuous stage motion and a laser intensity between 4600 and 5200 for MS spectra and 5200 for MS/MS spectra. Per spectrum, 400 shots were fired and the spectra accumulated to the final spectrum.

Prior to sample analysis each plate was calibrated using a calibration standard. The fragment ions of adrenocorticotropic hormone fragment 18-39 (2465.1989 Da) were used for MS/MS calibration. A list of peptides used for MS and MS/MS calibration can be found in Appendix X.

\subsubsection{One-dimensional gel electrophoresis}

Protein recovery and digestion during ICAT processing was monitored by onedimensional gel electrophoresis. The samples $(1 \mu \mathrm{l})$ were combined with $2.5 \mu \mathrm{l}$ LDS sample buffer (4x, NuPAGE®); Invitrogen, Carlsbad, CA), $1 \mu$ l reducing agent (10x, NuPAGE ${ }^{\circledR}$, Invitrogen) and 5.5 $\mu$ l High-Q water. The prepared samples were loaded on 
4-12\% Bis-Tris gels and electrophoresed at $200 \mathrm{~V}, 100 \mathrm{~mA}$ for $55 \mathrm{~min}$ in MOPS SDS running buffer (Invitrogen). To the buffer in the inner chamber $500 \mu$ lantioxidant (Invitrogen) was added before the start of the electrophoresis.

Electrophoresed gels were stained with Coomassie Briliant Blue G-250 (Bio-Rad, Hercules, $C A$ ). The gels were fixed in fixing solution ( $50 \%$ ethanol, $3 \%$ phosphoric acid) for 30 min with continuous shaking and washed in High-Q water three times for 30 min. Fixed gels were incubated for three days in staining solution containing $34 \%$ methanol, $17 \%$ ammonium sulphate, $3 \%$ phosphoric acid and $10 \mathrm{mg}$ Coomassie powder. The stained gels were washed with High-Q water three times for 30 min.

Images of the stained gels were acquired using an Image Scanner III (GE Healthcare, Uppsala, Sweden) controlled by LabScan 6.01 software (GE Healthcare) using transparency mode and a resolution of $200 \mathrm{dpi}$.

\subsubsection{Data analysis}

The acquired data were analysed with Mascot Distiller v. 2.4.3.3 (Matrix Science, UK) with the Quantitation Toolbox. Briefly, the raw data from the mass spectrometer were imported into Distiller. For each peak in the MS and MS/MS spectra the correlation between the predicted and the observed isotope distribution was calculated. Peaks with a correlation below 0.6 or a signal-to-noise ratio below 4 were rejected. The peak lists were than uploaded to Mascot (Perkins et al., 1999) to perform the searches. The results from the Mascot search were combined with the raw data and the identified peptides grouped together. From the raw data the intensity (peak area) of the identified ICAT pairs was calculated. Only peptides with a Mascot score indicating at least homology were included in the quantitation. In the case of a missing ICAT partner Distiller searched for parent ions matching the expected mass and which eluted in the same time frame. Another correlation coefficient between the predicted and the observed isotope distribution was used to detect interfering peaks. A correlation coefficient below 0.7 led to an exclusion of the quantitation. Precursors detected in multiple fractions were accumulated to one ratio and the standard error was calculated. For proteins with more than one peptide identified the geometrical standard deviation was calculated. 
The precursor masses and fragment ion peaks were searched against Uniprot, human, 30/10/2013, 850,499 sequences using the Mascot algorithm (Mascot Server v. 2.4.1, Matrix Science, London, UK). The search settings were 0.8 Da for both peptide and MS/MS tolerance, trypsin digestion with one missed cleavage, and ICAT ABI Cleavable as quantitation method.

Successfully identified peptides were quantified using the Quantitation Toolbox. Only peptides with a standard error below 0.1 and a correlation value above 0.7 were included in the quantitation. The quantitation were given as a ratio of peptides labelled with ICAT reagent light (L) to peptides labelled with ICAT reagent heavy $(H)$. The quantitation method was updated according to the Certificate of Analysis of the ICAT Kit to correct for impurities of ${ }^{13} \mathrm{C}$ in the heavy ICAT reagent. 


\section{Results}

\subsection{Cellular effects of GTX}

The cellular effects of GTX were initially examined using MTT. Preliminary experiments investigated the effects of culture medium, cell number, amount of GTX, and incubation time to establish the assay conditions (data not shown). The linearity of the assay was also investigated to confirm that measured changes in absorbance were proportional to metabolic reduction of $\mathrm{MTT}$. This was done using a range of cell numbers without exposure to GTX (Fig. 8). The response was linear over the

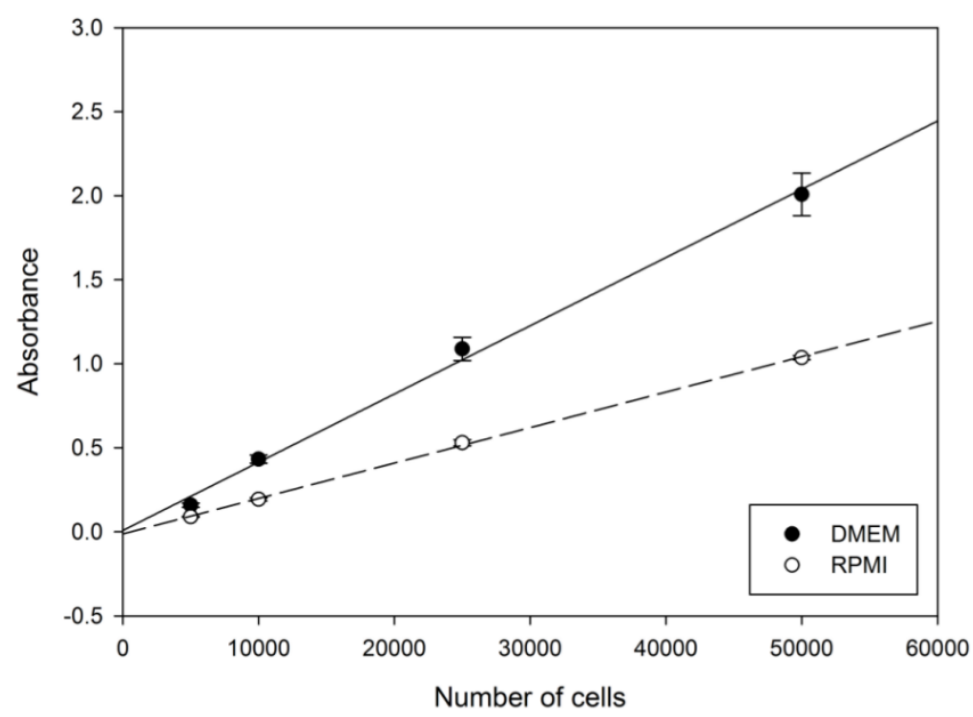
measured range and reduction was greater in Figure 8: Effects of cell number on relative absorption of MTT assay in different culture media. Representative results from three experiments. Cells were cultured in DMEM (filled circle) or RPMI (empty cicle). The DMEM than in RPMI. In experiemtens were conducted in 96-well plates. The error bars represent the standard deviation for three replicates.

general the expected

response of cytotoxic compounds in the MTT assay is to decrease metabolic reduction of MTT which is interpreted as a decrease in cell viability, but more precisely diminished metabolism. The preliminary experiments, however, had indicated that GTX enhanced the reduction of MTT by HL6o cells under some conditions, especially at high concentrations of GTX. Possible explanations included direct reduction of MTT by GTX dithiol produced from GTX disulfide by reaction with GSH or other cellular reducing systems.

For subsequent MTT experiments standard conditions were fixed at $2 \times 10^{4}$ cells/well (100 $\mu$ l incubates) in 96-well plates and the effects of GTX concentration and incubation time were investigated.

HL-60 cells treated with GTX for 24 h showed decreased viability starting at $10 \mathrm{ng} / \mathrm{ml}$ (Fig. 9). Cells cultured in RPMI seemed to be slightly less susceptible compared to cells in 


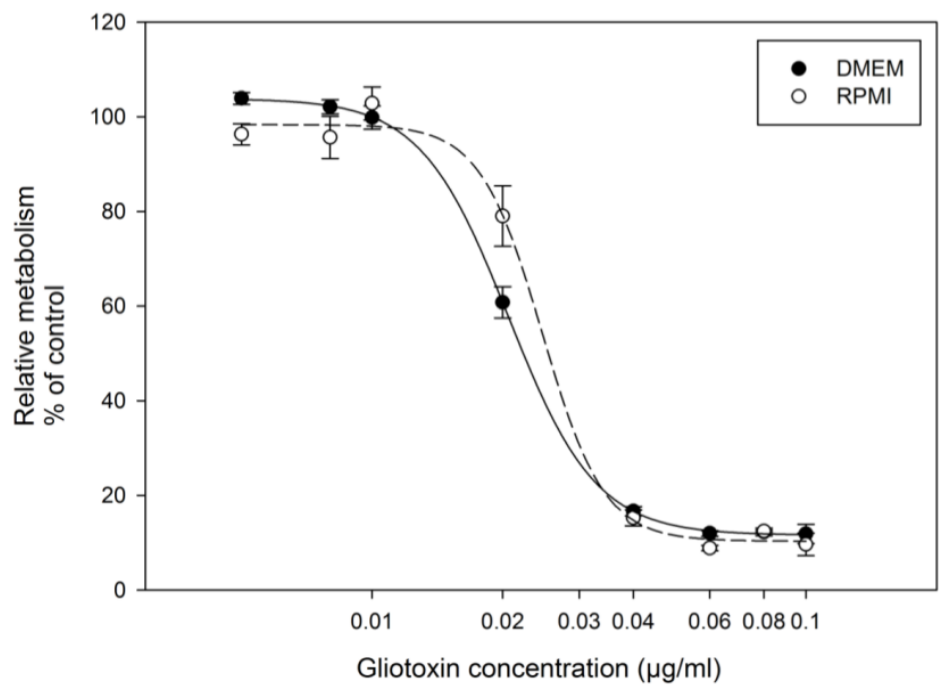

Figure 9: Concentration-dependent effects of GTX on HL-60 cell metabolism. Representative results from seven experiments conducted in 96-well plates. Cells were cultured in DMEM (filled circle, continuous line) or RPMI (empty circle, dashed line) in the presence of GTX. The error bars represent the standard deviation for three replicates.

DMEM. The IC50 values were approximately 77 and $86 \mathrm{nM}$ for DMEM and RPMI respectively.

Effects on the metabolism of MTT were less in cell exposed to GTX for 1 or $3 \mathrm{~h}$ (Fig. 10). Only small decreases in metabolism of MTT occurred when in cells in DMEM were exposed to GTX for $1 \mathrm{~h}$ although cells in RMPI seemed to be more sensitive to (Fig 10A). At $3 \mathrm{~h}$, however, there were greater losses in viability (Fig. 10B): GTX at $1 \mu \mathrm{g} / \mathrm{ml}$ again had less effect in DMEM, approximately $30 \%$ decrease in viability, compared to RPMI. Unexpectedly, reduction of MTT was less affected at $10 \mu \mathrm{g} / \mathrm{ml}$ GTX but this was not investigated further.

Culture in DMEM was used for all subsequent experiments, but cell numbers and

A

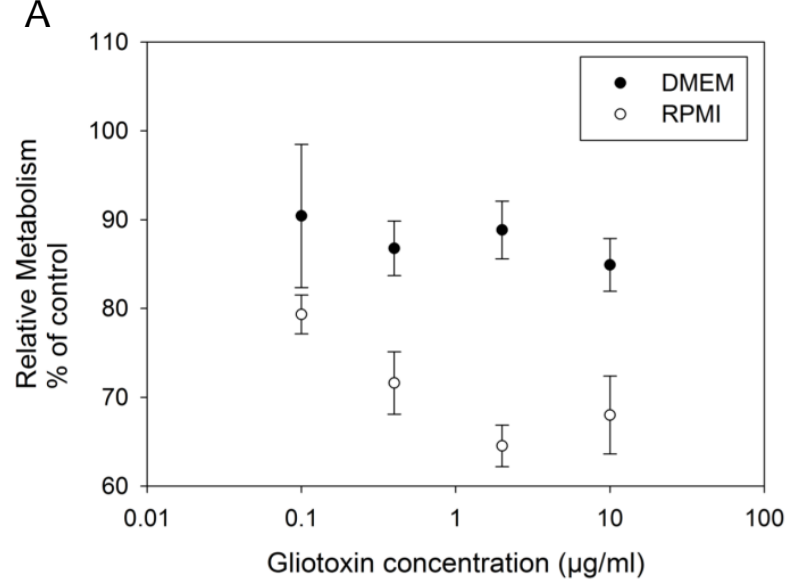

B

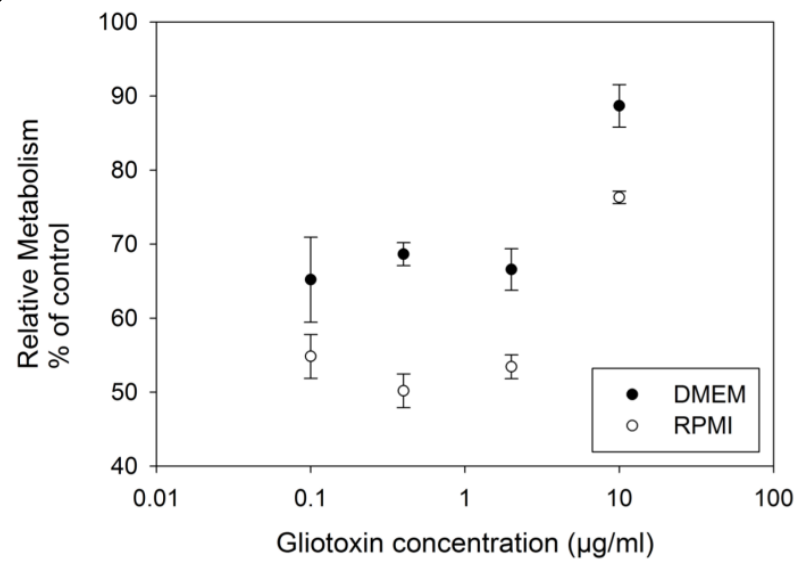

Figure 10: MTT results from HL-60 cells cultured in DMEM (filled circle) and RPMI (empty circle) and treatment with various GTX concentrations for $1 \mathrm{~h}(\mathrm{~A})$ and $3 \mathrm{~h}(\mathrm{~B})$. Representative results from five experiments in 96-well plates. The error bars represent the standard deviation of 3 replicates. The error bars represent the standard deviation of three replicates. 
culture volumes had to be adjusted depending on the numbers of cells required for different assays.

\subsubsection{Measurement of ROS production}

Some of the effects of GTX might be attributed to its capability to produce ROS. Dichlorofluorescein diacetate was therefore used as a probe to measure the production of ROS during GTX exposure. These experiments were carried out in 96-well plates using conditions similar to the MTT assays, namely $2 \times 10^{4}$ cells in $100 \mu \mathrm{I}$ DMEM per well. As a positive control, cells were exposed to $100 \mu \mathrm{M}$ hydrogen peroxide which resulted in an increase in fluorescence with greatest change in the first $45 \mathrm{~min}$ (Fig. 11). Untreated control cells, and cells cultured with $1 \mu \mathrm{g} / \mathrm{ml}$ and $10 \mu \mathrm{g} / \mathrm{ml} \mathrm{GTX}$, showed a much smaller increase in fluorescence signal over time.

\subsubsection{Effects of GTX on cell morphology}

For analysis of morphological change cultures in 24-well plates containing $10^{5}$ cells in $500 \mu \mathrm{l}$ DMEM were exposed to up to $5 \mu \mathrm{g} / \mathrm{ml} \mathrm{GTX}$ for $24 \mathrm{~h}$. Little obvious change was

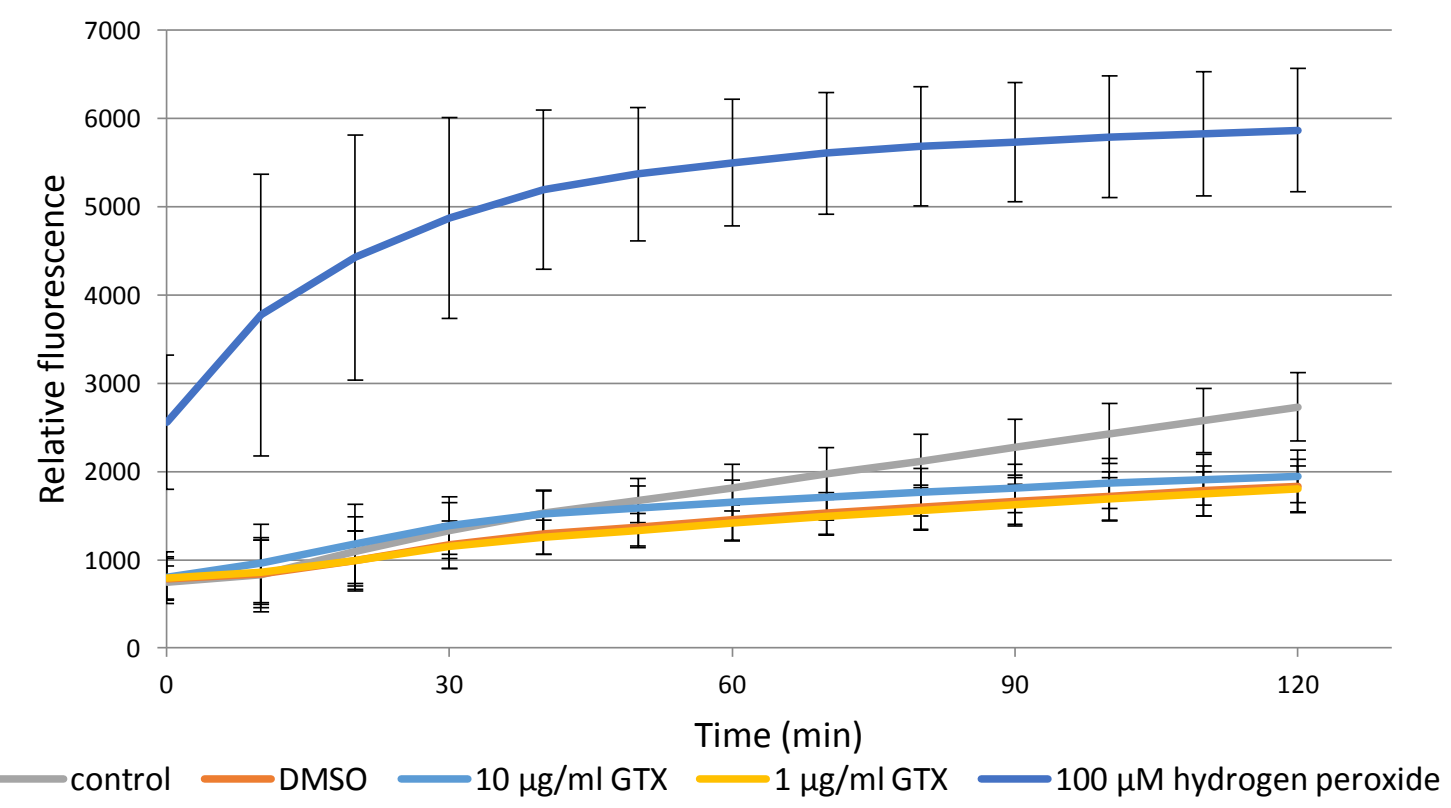

Figure 11: Changes in fluorescence of DCF-DA loaded cells after treatment with DMSO (red line), GTX (green and purple line), hydrogen peroxide (cyan line) and no treatment (blue line) over time. Cells were cultured in DMEM and loaded with DCF-DA. The fluorescence was measured dircetly after addition of the treatments. Shown are the representative results of five experiments conducted in 96-well plates with $2 \times 10^{4}$ cells per well. The error bars represent the standard deviation of three replicates. 
observed using phase contrast microscopy (Fig. 12) but the number of dead cells detected by trypan blue staining increased in the GTX-containing cultures.

\subsubsection{Cell cycle analysis}

Cell cycle analysis using DAPI staining was carried out using cells cultured in DMEM with GTX for 24 h. Control cells, and cells cultured with DMSO, showed G1 and G2 peaks with an apparent smaller population of apoptotic cells (Fig. 13). In three separate experiments, cells exposed to $0.1 \mu \mathrm{g} / \mathrm{ml}$ GTX showed little change from controls but culture for $24 \mathrm{~h}$ with $1 \mu \mathrm{g} / \mathrm{ml}$ GTX (Fig. $13 \mathrm{D}$ ) resulted in increased cell death and a $\mathrm{G}_{1}$ block of the cell cycle with the substantial loss of cells in $\mathrm{G}_{2} / \mathrm{M}$.

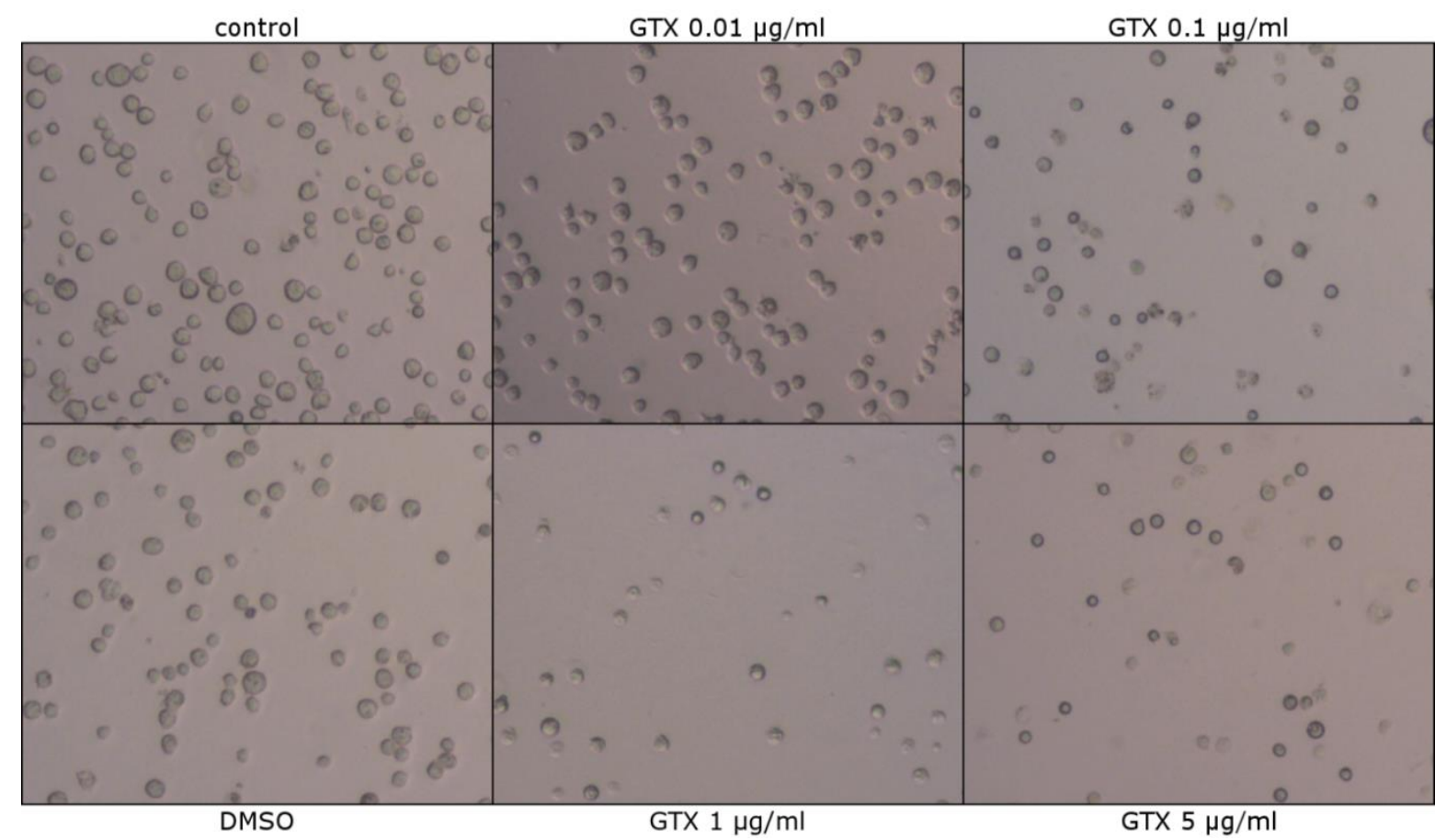

Figure 12: HL60 after 24h of treatment with different GTX concentrations, DMSO or no treatment. No obvious morphological changes were visible in the GTX-treated cells compared to control. Cells treated with GTX concentrations above $0.01 \mu \mathrm{g} / \mathrm{ml}$ showed a reduction in cell density. The cells were cultured in 24-well plates. 

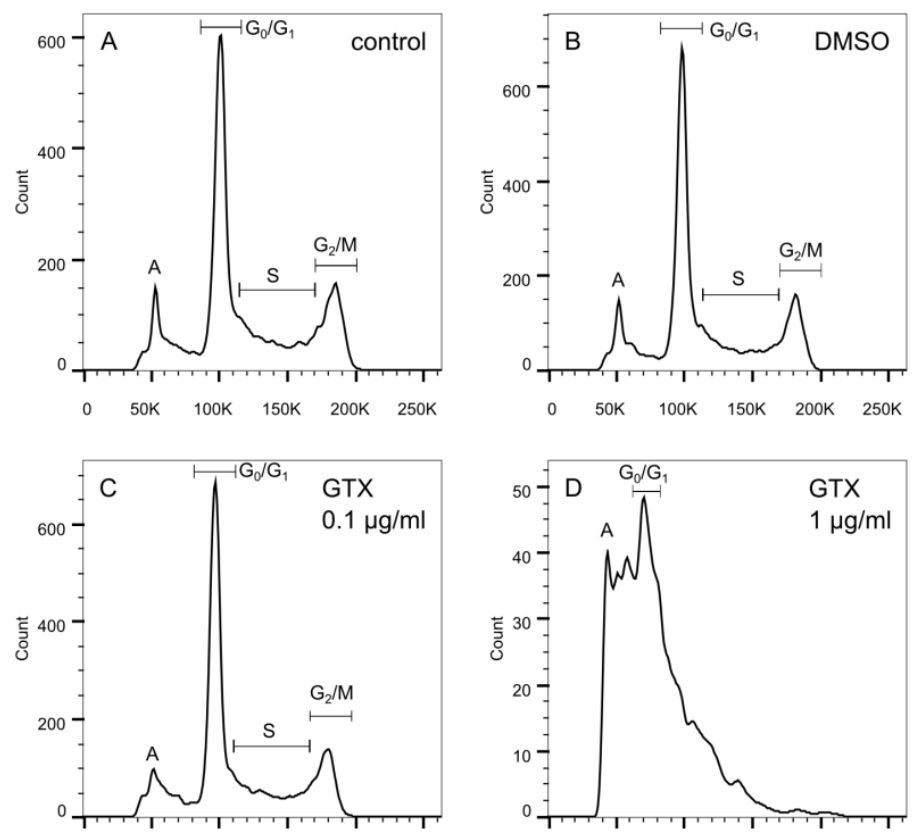

Figure 13: Cell cycle analysis of HL-60 cells treated with DMSO (B), GTX (C and D) and no treatment (A). Cells were cultured in DMEM in presence of the treatment for $24 \mathrm{~h}$ and stained with DAPI. A, apoptotic cells; $G_{0} / G_{1}, G_{0} / G_{1}$-phase; $S$, S-phase; $G_{2} / M, G_{2}-/$ mitotic phase.

\subsection{ICAT Analysis of Protein Modification}

\subsubsection{ICAT labelling of BSA}

Initially, the workflow was examined using a 1:1 mixture of light and heavy ICATlabelled BSA. Labelled peptides were examined using ion exchange cleanup prior to offline LC-MALDI in which peptides separated by LC on the TEMPO were mixed with CHCA matrix prior to MALDI MS and MS/MS. BSA was identified with a Mascot score of 18405 from a total of 661 MS ions representing 25 ICAT labelled peptide sequences. The protein sequence coverage was $41 \%$ (Fig. 14). The ratio between light and heavy labelled protein determined by Distiller was 0.94 with a geometrical standard deviation of 1.2. The resulting confidence interval was 0.78 to 1.14 . The protein false discovery rate (homology) was $1.4 \%$. Peptides with a standard error above 0.1 and a correlation below 0.7 were excluded from the quantitation leaving 21 of 25 peptides for the quantitation. The 
theoretical list of cysteine-containing tryptic peptides is shown in Table 1 and identified peptides with the corresponding ratios are in Table 1.

A representative peptide pair (CCTESLVNR, ratio L/H 0.9995) is shown in Figure 15A. The corresponding MS/MS spectra from the peptide with the light ICAT tag showed a y ion fragment (RNVLSETC) at 1148.61 Da (Fig. 15B). The same fragment of the heavy tagged peptide was at 1157.63 Da (Fig. 15C); illustrating the successful ICAT labelling and the resulting mass difference of 9 Da per labelled cys.

In a second experiment using BSA with a 1 to 4 (light:heavy) labelling ratio, the Mascot score was 7473 from 20 identified peptides (294 ICAT ions). The experimentally determined light:heavy (protein) ratio was 0.23 using 18 of the identified peptides with a geometrical standard deviation of 1.39, and a confidence interval of 0.16 to 0.32 . The reported protein FDR (homology) was $0.4 \%$ and the protein coverage was $45 \%$ (Fig. 14). The identified peptides with their $\mathrm{L} / \mathrm{H}$ ratios are listed in Table 1.

Not all of the potential cys-containg peptides were detected using the 1:1 labelling ratio, and less were detected with 1:4 labelling. In general, tryptic peptides terminated by arginine are more readily detected than those with lysine when using MALDI and the optimum mass range for peptide detection using CHCA matrix is $800-3000 \mathrm{~m} / \mathrm{z}$.

BSA sample ratio 1 to 1

\begin{tabular}{|c|c|c|c|}
\hline MKWVTFISLL & LLFSSAYSRG & VFRRDTHKSE & IAHRFKDLGE \\
\hline EHFKGLVLIA & FSQYLQQCPF & DEHVKLVNEL & TEFAKTCVAD \\
\hline ESHAGCEKSL & HTLFGDELCK & VASLRETYGD & MADCCEKQEP \\
\hline ERNECFLSHK & DDSPDLPKLK & PDPNTLCDEF & KADEKKFWGK \\
\hline YLYEIARRHP & YFYAPELLYY & ANKYNGVFQE & CCQAEDKGAC \\
\hline LLPKIETMRE & KVLASSARQR & LRCASIQKFG & ERALKAWSVA \\
\hline RLSQKFPKAE & FVEVTKLVTD & LTKVHKECCH & GDLLECADDR \\
\hline ADLAKYICDN & QDTISSKLKE & CCDKPLLEKS & HCIAEVEKDA \\
\hline IPENLPPLTA & DFAEDKDVCK & NYQEAKDAFL & GSFLYEYSRR \\
\hline HPEYAVSVLL & RLAKEYEATL & EECCAKDDPH & ACYSTVFDKL \\
\hline KHLVDEPQNL & IKQNCDQFEK & LGEYGFQNAL & IVRYTRKVPQ \\
\hline VSTPTLVEVS & RSLGKVGTRC & CTKPESERMP & CTEDYLSLIL \\
\hline NRLCVLHEKT & PVSEKVTKCC & TESLVNRRPC & FSALTPDETY \\
\hline VPKAFDEKLF & TFHADICTLP & DTEKQIKKQT & ALVELLKHKP \\
\hline KATEEQLKTV & MENFVAFVDK & CCAADDKEAC & FAVEGPKLVV \\
\hline
\end{tabular}

BSA sample ratio 1 to 4

MKWVTFISLL LLFSSAYSRG VFRRDTHKSE IAHRFKDLGE EHFKGLVLIA FSQYLQQCPF DEHVKLVNEL TEFAKTCVAD ESHAGCEKSL HTLFGDELCK VASLRETYGD MADCCEKQEP ERNECFLSHK DDSPDLPKLK PDPNTLCDEF KADEKKFWGK YLYEIARRHP YFYAPELLYY ANKYNGVFQE CCQAEDKGAC LLPKIETMRE KVLASSARQR LRCASIQKFG ERALKAWSVA RLSQKFPKAE FVEVTKLVTD LTKVHKECCH GDLLECADDR ADLAKYICDN QDTISSKLKE CCDKPLLEKS HCIAEVEKDA IPENLPPLTA DFAEDKDVCK NYQEAKDAFL GSFLYEYSRR HPEYAVSVLL RLAKEYEATL EECCAKDDPH ACYSTVFDKL KHLVDEPQNL IKQNCDQFEK LGEYGFQNAL IVRYTRKVPQ VSTPTLVEVS RSLGKVGTRC CTKPESERMP CTEDYLSLIL NRLCVLHEKT PVSEKVTKCC TESLVNRRPC FSALTPDETY VPKAFDEKLF TFHADICTLP DTEKQIKKQT ALVELLKHKP KATEEQLKTV MENFVAFVDK CCAADDKEAC FAVEGPKLVV STQTALA

Figure 14: Comparison of protein coverage of the two BSA samples. Red indicates identified peptides and blue theoretical not identified cys-containing peptides. 
Table 1: Theoretical cys-containing tryptic peptides of BSA. MC, missed cleavages; I, identified but excluded from quantitation. Oxidation of methionine was used as variable modification during database searches.

\begin{tabular}{|c|c|c|c|c|c|}
\hline \multirow{2}{*}{$\begin{array}{l}\text { Peptide } \\
\text { mass }\end{array}$} & \multirow[t]{2}{*}{ MC } & \multirow[t]{2}{*}{ Peptide sequence } & \multirow{2}{*}{$\begin{array}{l}\text { \# of } \\
\text { cys }\end{array}$} & \multicolumn{2}{|c|}{ L/H ratios } \\
\hline & & & & $\begin{array}{l}\text { BSA } \\
1: 1\end{array}$ & $\begin{array}{l}\text { BSA } \\
1: 4\end{array}$ \\
\hline 3579.856 & 1 & GLVLIAFSQYLQQCPFDEHV KLVNELTEFAK & 1 & & \\
\hline 3503.571 & 1 & HPYFYAPELLYYANKYNGVF QECCQAEDK & 2 & & \\
\hline 3390.683 & 1 & DLGEEHFKGLVLIAFSQYLQ QCPFDEHVK & 1 & & \\
\hline 2952.429 & 1 & SHCIAEVEKDAIPENLPPLT ADFAEDK & 1 & & \\
\hline 2867.184 & 1 & EYEATLEECCAKDDPHACYS TVFDK & 3 & & \\
\hline $2829 \cdot 337$ & 1 & CCTESLVNRRPCFSALTPDE TYVPK & 3 & & \\
\hline 2701.245 & 1 & CCTKPESERMPCTEDYLSLI LNR & 3 & & \\
\hline 2693.200 & 1 & TCVADESHAGCEKSLHTLFG DELCK & 3 & & \\
\hline 2494.159 & 1 & LVNELTEFAKTCVADESHAG CEK & 2 & & \\
\hline 2490.255 & 1 & MPCTEDYLSLILNRLCVLHE K & 2 & & \\
\hline 2472.198 & 1 & QNCDQFEKLGEYGFQNALIV R & 1 & & \\
\hline 2441.169 & 1 & AFDEKLFTFHADICTLPDTE K & 1 & & \\
\hline 2435.243 & 0 & GLVLIAFSQYLQQCPFDEHV K & 1 & & \\
\hline 2414.170 & 1 & RPCFSALTPDETYVPKAFDEK & 1 & & \\
\hline 2401.159 & 1 & DAIPENLPPLTADFAEDKDVCK & 1 & I & 0.21 \\
\hline 2387.144 & 1 & DDSPDLPKLKPDPNTLCDEF K & 1 & & \\
\hline 2316.046 & 1 & YNGVFQECCQAEDKGACLLPK & 3 & & \\
\hline 2298.118 & 1 & HLVDEPQNLIKQNCDQFEK & 1 & & \\
\hline 2220.137 & 1 & LFTFHADICTLPDTEKQIK & 1 & & \\
\hline 2174.029 & 1 & ECCDKPLLEKSHCIAEVEK & 3 & & \\
\hline 2105.934 & 1 & TVMENFVAFVDKCCAADDK & 2 & 0.68 & \\
\hline 2121.929 & 1 & TVMENFVAFVDKCCAADDK + Oxidation & 2 & 0.80 & 0.21 \\
\hline 2076.878 & 1 & ECCHGDLLECADDRADLAK & 3 & 1.46 & \\
\hline 2034.058 & 1 & EACFAVEGPKLVVSTQTALA & 1 & & \\
\hline 2003.778 & 1 & ETYGDMADCCEKQEPER & 2 & 0.77 & \\
\hline 2019.773 & 1 & ETYGDMADCCEKQEPER + Oxidation & 2 & I & \\
\hline 1962.948 & 1 & LKPDPNTLCDEFKADEK & 1 & & \\
\hline 1942.820 & 1 & VHKECCHGDLLECADDR & 3 & 0.84 & \\
\hline 1890.803 & 1 & VASLRETYGDMADCCEK & 2 & & \\
\hline 1888.995 & 1 & SLHTLFGDELCKVASLR & 1 & & \\
\hline 1884.901 & 1 & ADLAKYICDNQDTISSK & 1 & & \\
\hline 1850.899 & 0 & LFTFHADICTLPDTEK & 1 & 0.97 & 0.21 \\
\hline 1844.848 & 1 & NECFLSHKDDSPDLPK & 1 & & \\
\hline 1823.900 & 0 & RPCFSALTPDETYVPK & 1 & 1.00 & 0.30 \\
\hline 1756.734 & 1 & CCAADDKEACFAVEGPK & 3 & 0.79 & 0.14 \\
\hline 1738.811 & 1 & DDPHACYSTVFDKLK & 1 & 0.78 & 0.16 \\
\hline 1700.787 & 1 & LAKEYEATLEECCAK & 2 & & \\
\hline 1667.813 & 0 & MPCTEDYLSLILNR & 1 & 0.92 & 0.29 \\
\hline 1683.808 & 0 & MPCTEDYLSLILNR + Oxidation & 1 & 0.97 & 0.21 \\
\hline 1633.662 & 0 & YNGVFQECCQAEDK & 2 & & \\
\hline 1627.800 & 1 & YICDNQDTISSKLK & 1 & & \\
\hline 1616.749 & 1 & QEPERNECFLSHK & 1 & & 0.43 \\
\hline 1578.598 & 0 & ECCHGDLLECADDR & 3 & 0.86 & 0.19 \\
\hline 1519.746 & 0 & LKPDPNTLCDEFK & 1 & & 0.20 \\
\hline 1497.631 & 0 & DDPHACYSTVFDK & 1 & & \\
\hline
\end{tabular}




\begin{tabular}{|c|c|c|c|c|c|}
\hline \multirow{2}{*}{$\begin{array}{l}\text { Peptide } \\
\text { mass }\end{array}$} & \multirow[t]{2}{*}{ MC } & \multirow[t]{2}{*}{ Peptide sequence } & \multirow{2}{*}{$\begin{array}{l}\text { \# of } \\
\text { cys }\end{array}$} & \multicolumn{2}{|c|}{ L/H ratios } \\
\hline & & & & $\begin{array}{l}\text { BSA } \\
1: 1\end{array}$ & $\begin{array}{l}\text { BSA } \\
1: 4\end{array}$ \\
\hline 1482.798 & 1 & LCVLHEKTPVSEK & 1 & & \\
\hline 1465.689 & 1 & VGTRCCTKPESER & 2 & & \\
\hline 1418.738 & 1 & LKECCDKPLLEK & 2 & & \\
\hline 1388.571 & 0 & EYEATLEECCAK & 2 & 1.00 & 0.30 \\
\hline 1386.621 & 0 & YICDNQDTISSK & 1 & 0.96 & I \\
\hline 1364.480 & 0 & ETYGDMADCCEK & 2 & & \\
\hline 1380.475 & 0 & ETYGDMADCCEK + Oxidation & 2 & 1.49 & \\
\hline 1362.672 & 0 & SLHTLFGDELCK & 1 & 0.96 & 0.22 \\
\hline 1352.666 & 1 & VTKCCTESLVNR & 2 & & \\
\hline $1349 \cdot 546$ & 0 & TCVADESHAGCEK & 2 & 0.91 & 0.23 \\
\hline 1331.717 & 1 & GACLLPKIETMR & 1 & & \\
\hline 1197.557 & 1 & DVCKNYQEAK & 1 & & \\
\hline 1177.559 & 0 & ECCDKPLLEK & 2 & 1.01 & I \\
\hline 1138.567 & 1 & CASIQKFGER & 1 & & \\
\hline 1052.450 & 0 & CCTKPESER & 2 & 0.99 & 0.39 \\
\hline 1050.492 & 0 & EACFAVEGPK & 1 & 0.98 & 0.26 \\
\hline 1024.455 & 0 & CCTESLVNR & 2 & 1.00 & 0.39 \\
\hline 1015.488 & 0 & SHCIAEVEK & 1 & I & 0.13 \\
\hline 1011.420 & 0 & QNCDQFEK & 1 & & \\
\hline 977.4509 & 0 & NECFLSHK & 1 & & \\
\hline 918.5189 & 1 & LRCASIQK & 1 & & \\
\hline 841.460 & 0 & LCVLHEK & 1 & & \\
\hline 725.2593 & 0 & CCAADDK & 2 & I & \\
\hline 701.4014 & 0 & GACLLPK & 1 & & \\
\hline 649.3338 & 0 & CASIQK & 1 & & \\
\hline 464.2173 & 0 & DVCK & 1 & & \\
\hline
\end{tabular}




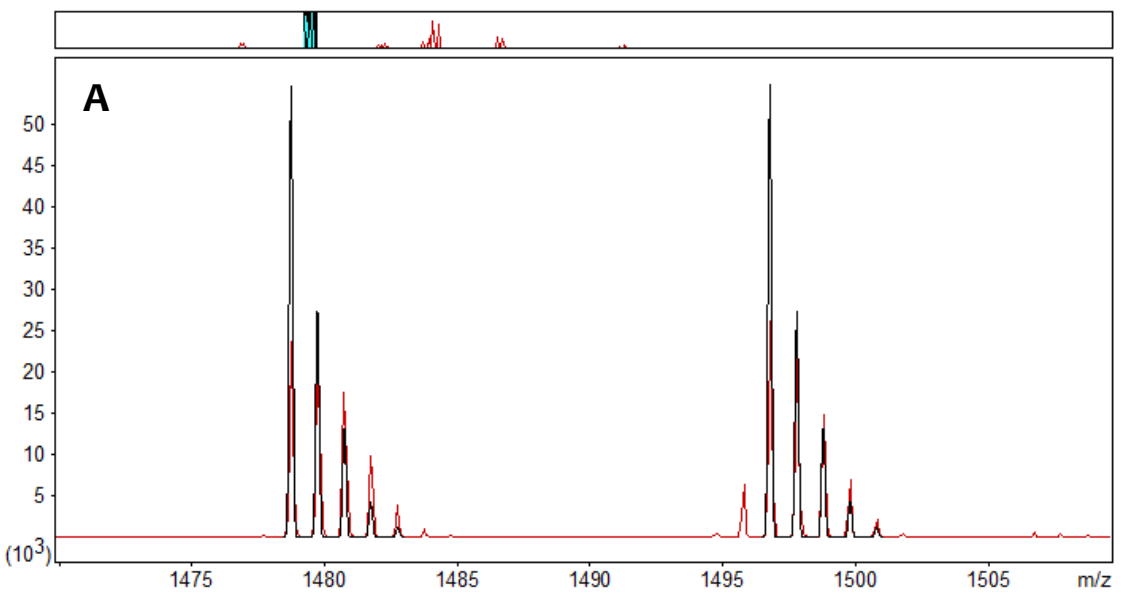

Figure 15: MS of an ICAT pair of the peptide CCTESLVNR (A). The red line represents the accquired spectra and the black line shows the area used for the quantitation. The section of the MS/MS of the light ICAT labelled petide shows the $y$-ion fragment 8 at $\mathrm{m} / \mathrm{z} 1148.6$ (B). The same $y$-ion from the heavy labelled peptide was at $1157.6(\mathrm{C})$. The blue lines represent the $y$-ion series and the green on the $b$ ion series. The same peptide

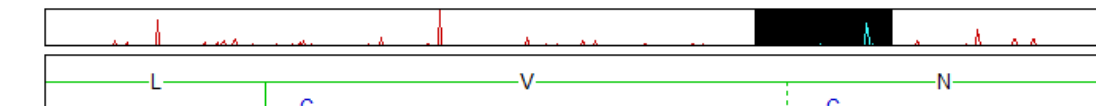
of the 1 to 4 sample showed an increased intensity of the heavy labelled peptide (D).
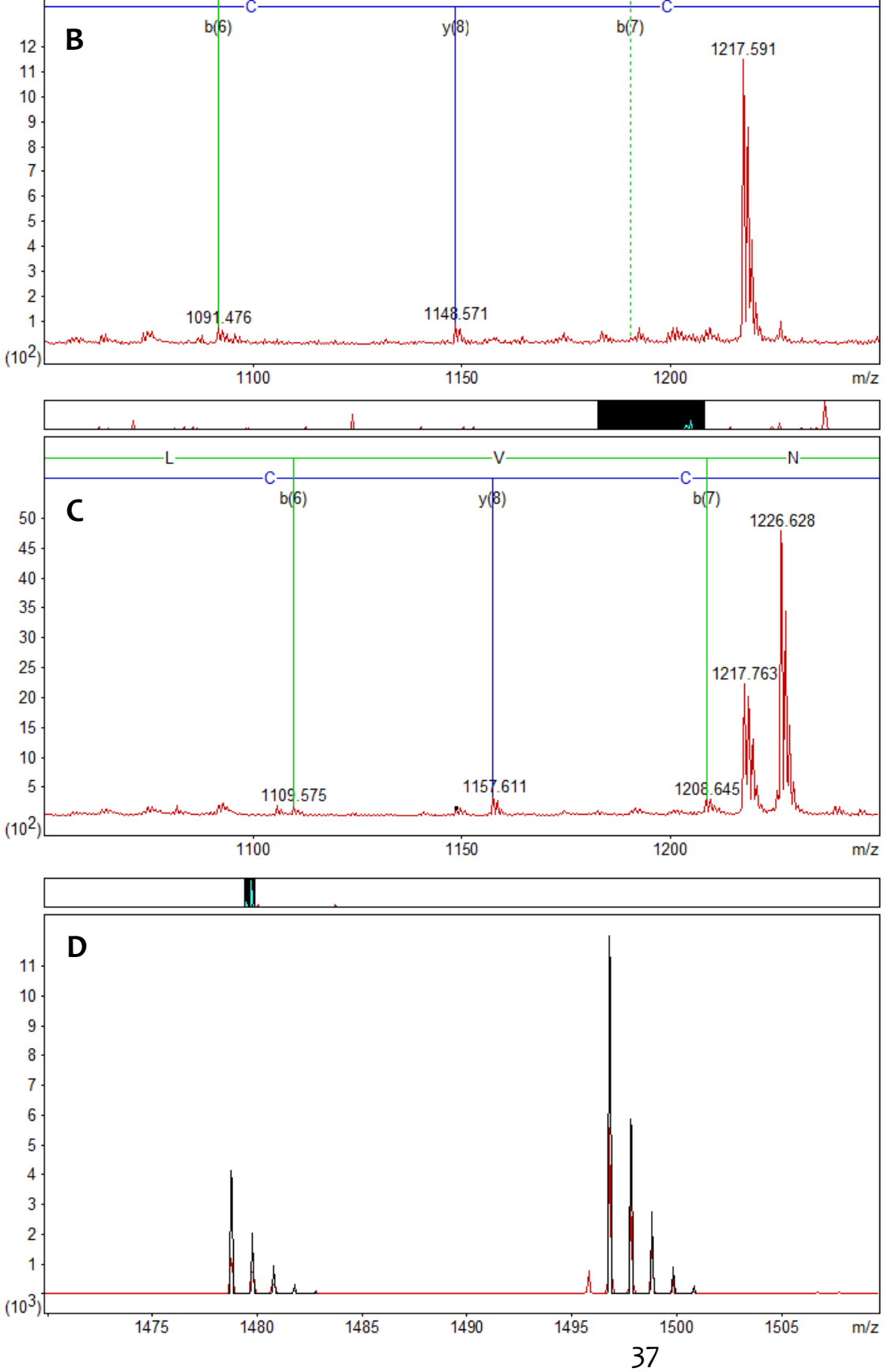


\subsubsection{ICAT analysis of the effects of GTX on HL60 cells}

ICAT was originally developed as a method for comparison of variation in protein abundance based on labelling free cysteinyl residues. In this approach biological extracts are reduced to convert oxidized protein cysteines, including disulfides, to the free thiols prior to labelling with ICAT reagents (Gygi et al., 1999; Hansen et al., 2003). Alternatively, as investigated here, the reduction step can be omitted to probe differences in cysteine reactivity between experimental groups. The hypotheses for my experiments are that: GTX modifies cysteinyl residues by either (1) reaction of GTX disulfide with protein thiols to form mixed disulfide adducts, or (2) by oxidation of cysteine through the production of ROS, or (3) possibly by interaction of GTX dithiol with protein disulfides; and that such changes may be detected by non-reductive labelling with ICAT reagents.

In total, three ICAT experiments were carried out (Table 2). In all experiments $9 \mathrm{x}$ $10^{6}$ cells cultured for $3 \mathrm{~h}$ in DMEM were used. In the first two experiments proteins from cells that had been exposed to $1 \mu \mathrm{g} / \mathrm{ml}$ GTX (added in DMSO) were heavy-labelled and compared to light-labelled proteins from control cells that had been incubated with $1 \mu \mathrm{l} / \mathrm{ml}$ DMSO. Experiments Two (2a) and Three (2b) were carried out together with comparison of light and heavy labelled control cells in the third experiment (Table 2). One-dimensional SDS-PAGE was used to confirm tryptic digestion during sample processing. The MALDI MS of total peptide extracts was used to confirm the presence of peptides before and after the chromatographic steps, and off-line (TEMPO) MALDI was used for peptide identification and analysis of ICAT labelling.

Table 2: Overview of the ICAT experiments with the respective treatment and labelling strategy.

\begin{tabular}{clll}
\hline$\#$ & Sample & Treatment $(3 \mathrm{~h})$ & Label \\
\hline 1 & HL-60 & DMSO $(1 \mu \mathrm{l} / \mathrm{ml})$ & ICAT light \\
& HL-60 & GTX $(1 \mu \mathrm{m} / \mathrm{ml})$ & ICAT heavy \\
\hline 2a & HL-60 & DMSO $(1 \mu \mathrm{l} / \mathrm{ml})$ & ICAT light \\
& HL-60 & GTX $(1 \mu \mathrm{m} / \mathrm{ml})$ & ICAT heavy \\
\hline 2b & HL-60 & - & ICAT light \\
& HL-60 & - & ICAT heavy \\
\hline
\end{tabular}




\subsubsection{ICAT Experiment One: Comparison of GTX-exposed with control cell extracts}

HL-6o cells were exposed to GTX or DMSO (control) as indicated in Table 2 and labelled with ICAT reagents. Sample processing was monitored by SDS PAGE (Fig 16). There were some differences (arrows) in the protein profiles of GTX and DMSO exposed cells before labelling. Protein bands at $100 \mathrm{kDa}, 16 \mathrm{kDa}$ and $12 \mathrm{kDa}$ were more intense in the GTX treated sample, while a band at >250 kDa was more intense in the DMSO-treated sample (Fig. 16A). Although the ICAT-labelled samples were more dilute there was staining of sample proteins but the bands were too faint to confirm any differences (Fig. 16B). Lane GD (Fig. 16C) represents the tryptic digest of combined light and heavylabelled samples prior to chromatography and cleavage of the biotin tag. As expected, protein was not detected in the tryptic digest although sample dilution was not greater than in the ICAT-labelled lanes. Accumulation of Coomassie staining was visible at the electrophoresis front suggesting the presence of peptides resulting from the tryptic

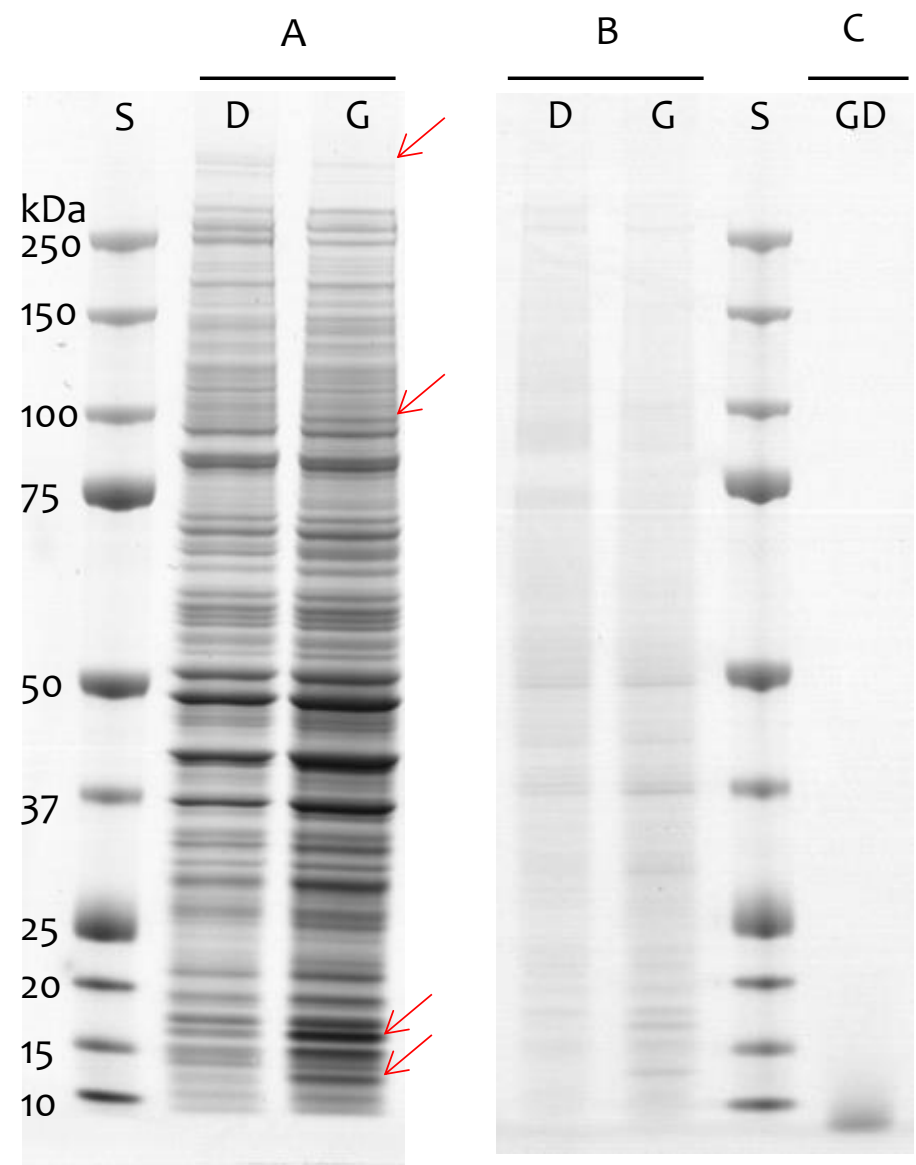

Figure 16: 1D gel of cells treated with DMSO (D) and GTX (G) before (A) and after ICAT labelling (B), and after trypsin digest (C). Arrows indicate the changes in the GTX-treated sample. 
digestion.

Prior to RP-LC fractionation the presence of peptides and ICAT pairs was verified by MALDI MS. Post-avidin-cleanup samples were combined with matrix and spotted on a MALDI target plate. MS analysis showed ten putative ICAT pairs (Fig. 17). These ICAT pairs confirmed the successful labelling with the ICAT reagents.

The labelled peptides were fractionated by RP-LC and spotted onto a MALDI plate using the TEMPO LC-spotter. The UV-trace showed elution of peptides in fractions 50 to 95 (Fig. 18). MALDI MS and MS/MS of 210 LC fractions resulted in matching of 35 MS ions to nine putative ICAT-labelled cys-containing peptides from eight proteins (Table 3). Two different peptide sequences matched to peptidyl-prolyl cis-trans isomerase. Of these nine peptides, six showed light to heavy ICAT ratios ranging from 0.22 to 4.02 with only one apparent pair having a ratio near unity (isoform 4 of Protein sidekick-2). Proteins that showed apparent loss following exposure to GTX (light/heavy $>1$ ) included tubulin beta4A chain, glyceraldehyde-3-phosphate dehydrogenase and peptidyl-prolyl cis-trans isomerase. Two proteins (albumin, hnRNP A1) had ratios < 1 indicating increase following exposure to GTX.

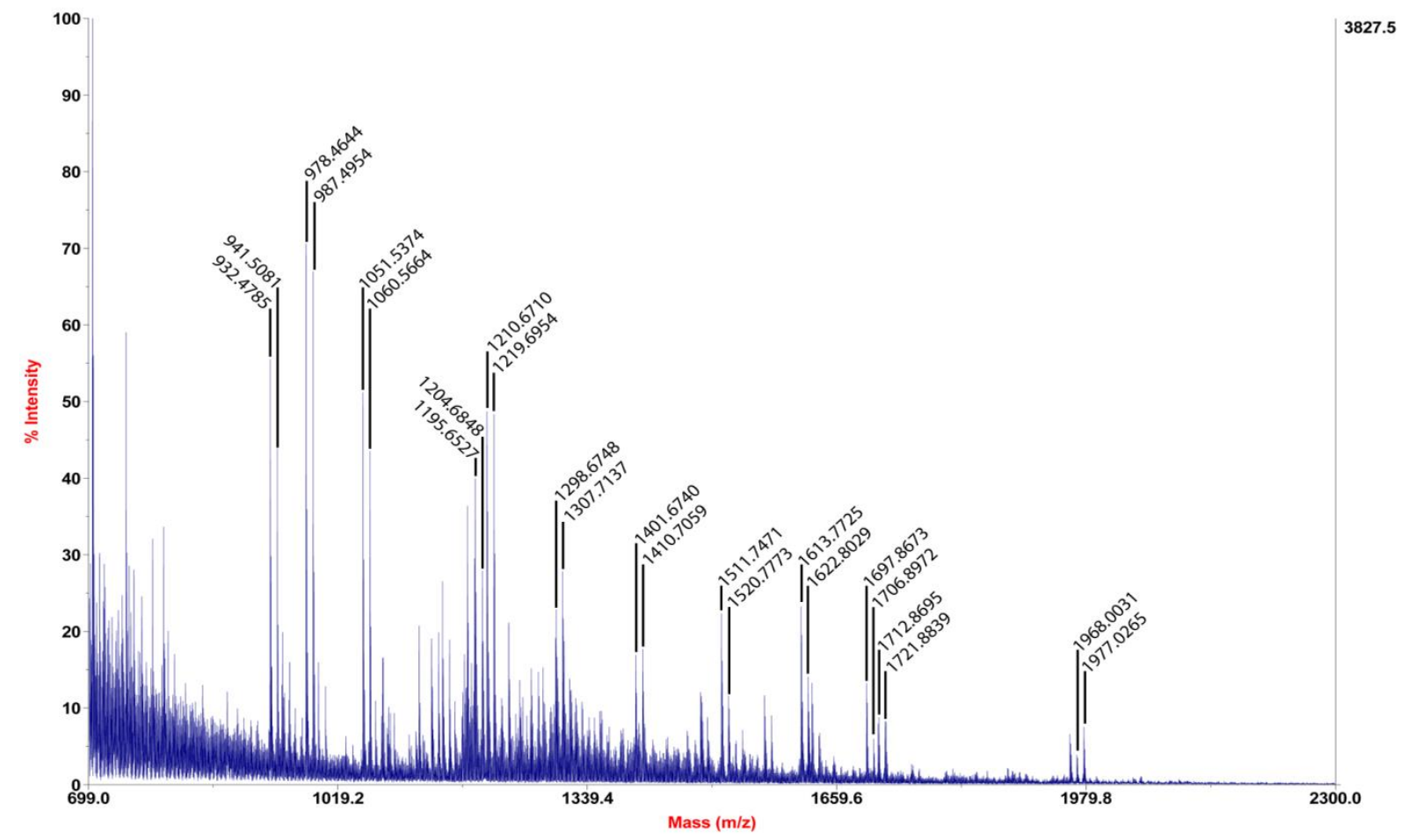

Figure 17: MS of ICAT labelled peptides from Experiment One prior to RP-LC fractionation. 


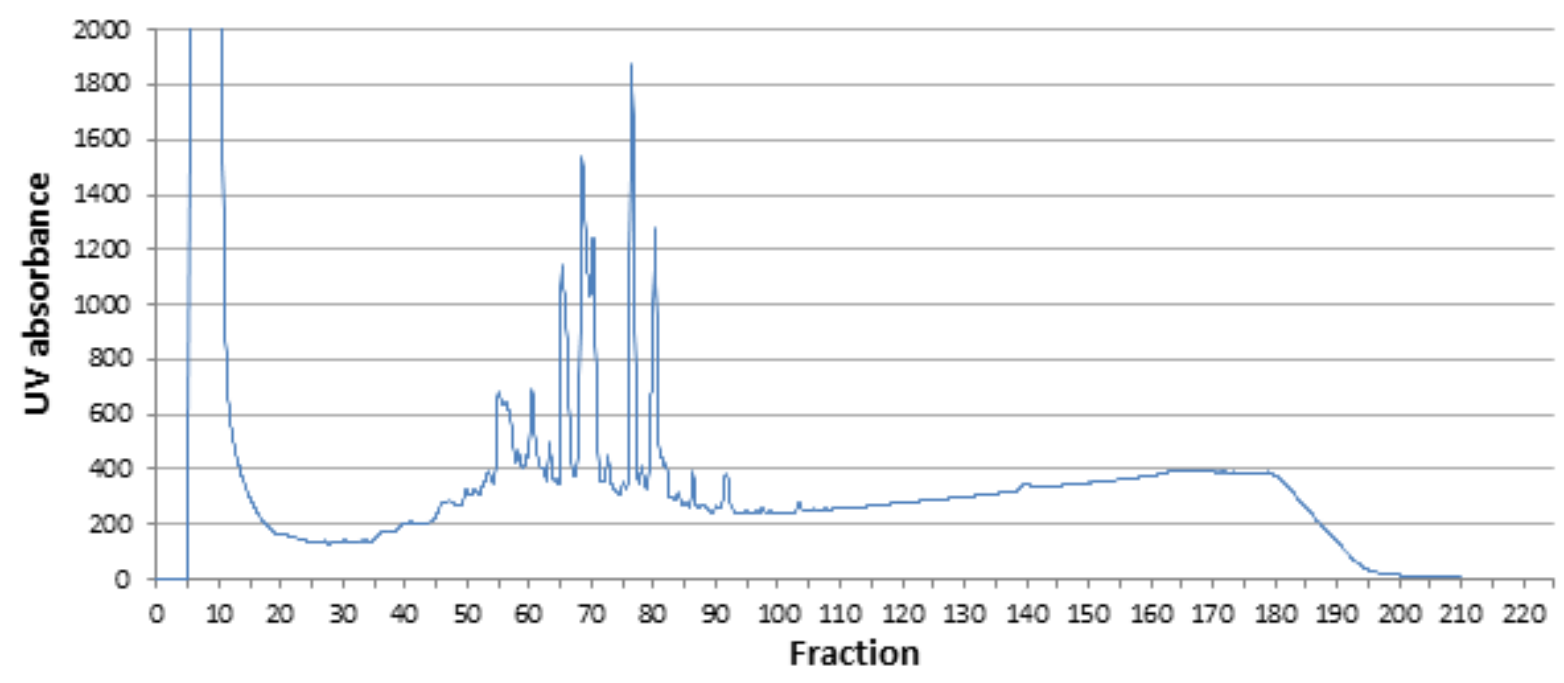

Figure 18: UV trace of the RP separation of ICAT labelled peptides from Experiment One using the TEMPO LC-spotter.

For pyruvate kinase and CDNA FLJ56548 quantitation was not possible as the standard error of the accumulated ratios was higher than 0.1 , therefor the peptides were rejected from the quantitation. The standard error represents the variation within these precursors.

Table 3: List of identified proteins, accession numbers and ratios from Experiment One.

\begin{tabular}{|c|c|c|c|c|c|}
\hline & Protein description & $\begin{array}{l}\text { Uniprot } \\
\text { accession } \\
\#\end{array}$ & Score $^{1}$ & $\begin{array}{l}\text { Ratio } \\
\text { Light/ } \\
\text { Heavy }\end{array}$ & Sequence \\
\hline 1 & Tubulin beta-4A chain & MoQX14 & 169 & $4.0228^{2}$ & ${ }_{3}$ EIVHLQAGQCGNQIGAK $_{19}$ \\
\hline 2 & $\begin{array}{l}\text { Glyceraldehyde-3- } \\
\text { phosphate } \\
\text { dehydrogenase }\end{array}$ & QOQET7 & 164 & $1.8975^{2}$ & ${ }_{210}$ VPTANVSVVDLTCR ${ }_{223}$ \\
\hline 3 & $\begin{array}{l}\text { Peptidyl-prolyl cis-trans } \\
\text { isomerase }\end{array}$ & $\mathrm{B} 4 \mathrm{DM} 82$ & 145 & $2.3715^{3}$ & ${ }_{56}{ }^{I I P G F M C Q G G D F T R}{ }_{69}$ \\
\hline 4 & Serum albumin & HoYA55 & 111 & $0.2174^{2}$ & ${ }_{345} \mathrm{CCTESLVNR}_{353}$ \\
\hline 5 & $\begin{array}{l}\text { Heterogeneous nuclear } \\
\text { ribonucleoprotein A } 1 \\
\text { (Fragment) }\end{array}$ & HOYH8O & 39 & $0.4595^{2}$ & ${ }_{38} \mathrm{YHTVNGHNCEVR}_{49}$ \\
\hline 6 & $\begin{array}{l}\text { CDNA FLJ } 56548 \text {, highly } \\
\text { similar to Elongation } \\
\text { factor } 2\end{array}$ & $\mathrm{~B}_{4} \mathrm{DPU}_{3}$ & 37 & $\begin{array}{l}\text { No } \\
\text { quantific } \\
\text { ation }^{4}\end{array}$ & ${ }_{436}$ CLYASVLTAQPR $_{447}$ \\
\hline 7 & Pyruvate kinase & $\mathrm{H}_{3} \mathrm{BQ} 34$ & 31 & $\begin{array}{l}\text { No } \\
\text { quantific } \\
\text { ation }^{4}\end{array}$ & ${ }_{44} \mathrm{NTGIICTIGPASR}_{56}$ \\
\hline 8 & $\begin{array}{l}\text { Isoform } 4 \text { of Protein } \\
\text { sidekick-2 }\end{array}$ & Q58EX2-4 & 25 & $1.1280^{2}$ & ${ }_{2169} M_{\text {CVASSSSALR }}{ }_{2179}$ \\
\hline
\end{tabular}




\subsubsection{ICAT Experiment Two (2a): Comparison of GTX-exposed with control cell extracts}

HL-60 cells were prepared as indicated in Table 1. Again, the sample processing was monitored by SDS PAGE (Fig 19). There were the same differences (arrows) in the protein profiles of GTX and DMSO exposed cells before labelling as in Experiment One, except for the protein band at $100 \mathrm{kDa}$ that in this experiment did not differ between the GTXand the DMSO-treated samples (Fig. 19A). As in Experiment One, the higher dilution of the ICAT-labelled samples prevented a precise analysis of the protein bands but nevertheless confirmed the presence of proteins after the labelling (Fig. 19B). The tryptic digest of combined light and heavy-labelled samples prior to further processing showed no visible protein bands for GTX- and DMSO-treated samples (Fig. 19C, lane GD) or for the control samples (Fig. 12C, lane $\mathrm{C}_{1} \mathrm{C} 2$ ).

The presence of peptides and ICAT pairs was verified by MALDI MS of the samples eluted from the avidin column. A total of eight putative pairs could be identified (Fig. 20).

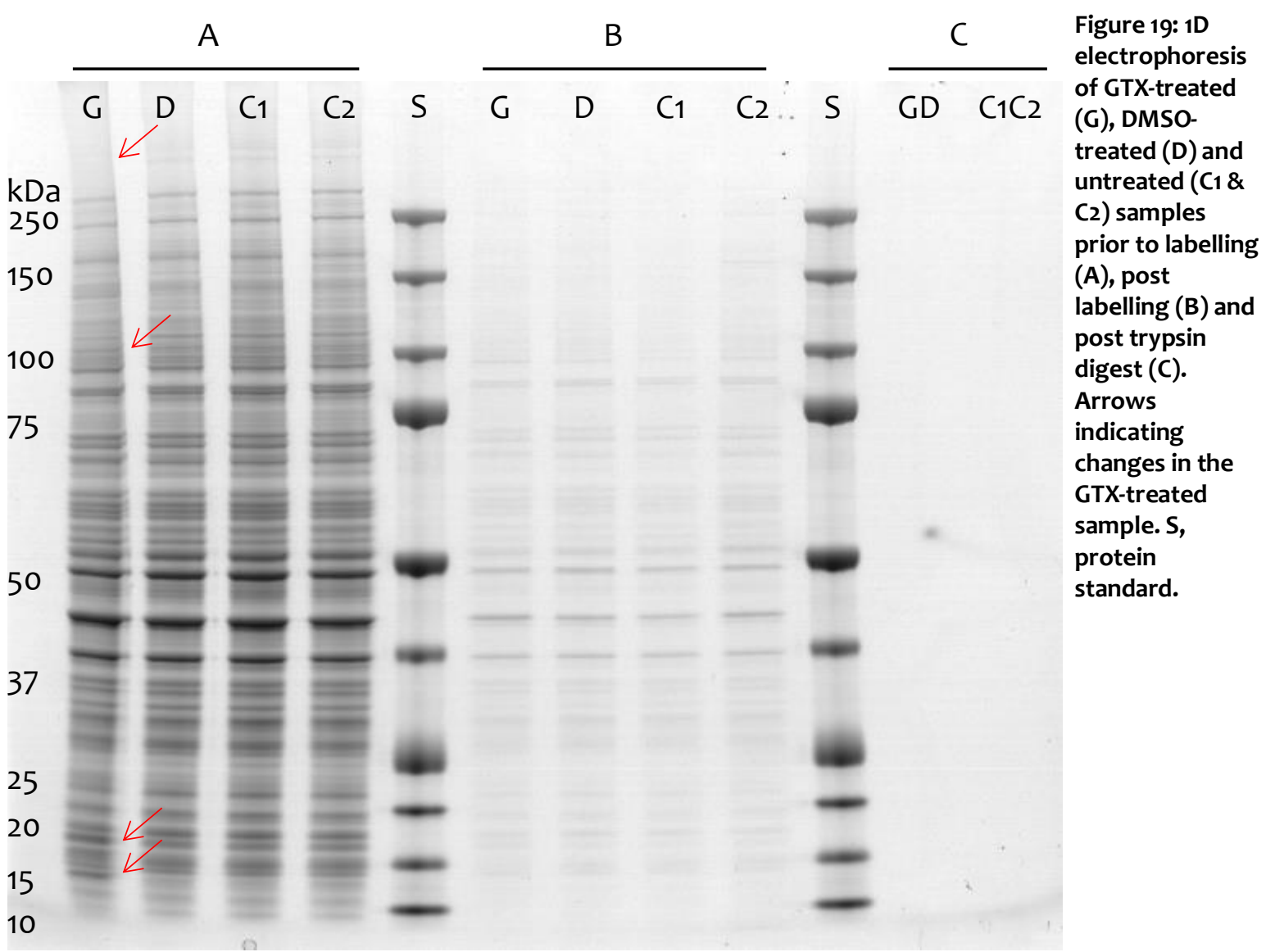




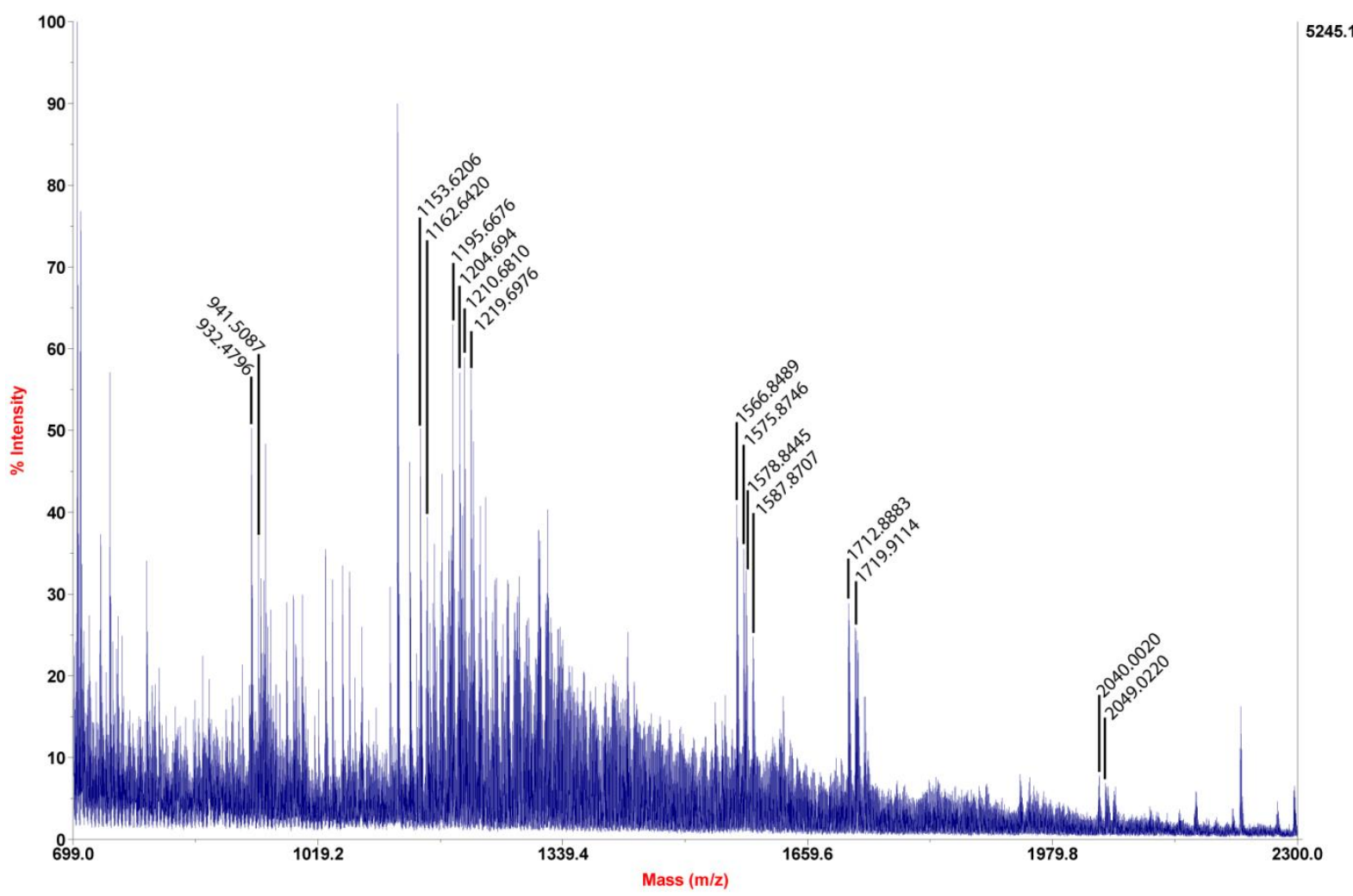

Figure 20: MS spectra of ICAT labelled peptides from Experiment 2a prior to RP-LC fractionationing.

Three pairs were similar to the ones from Experiment One: 1195/1204, 1210/1219 and $1712 / 1721$.

The LC method was modified to achieve a better resolution. The proportion of LC reagent B was changed from $20 \%$ to $50 \%$ over 30 min followed by steep increase to $80 \%$

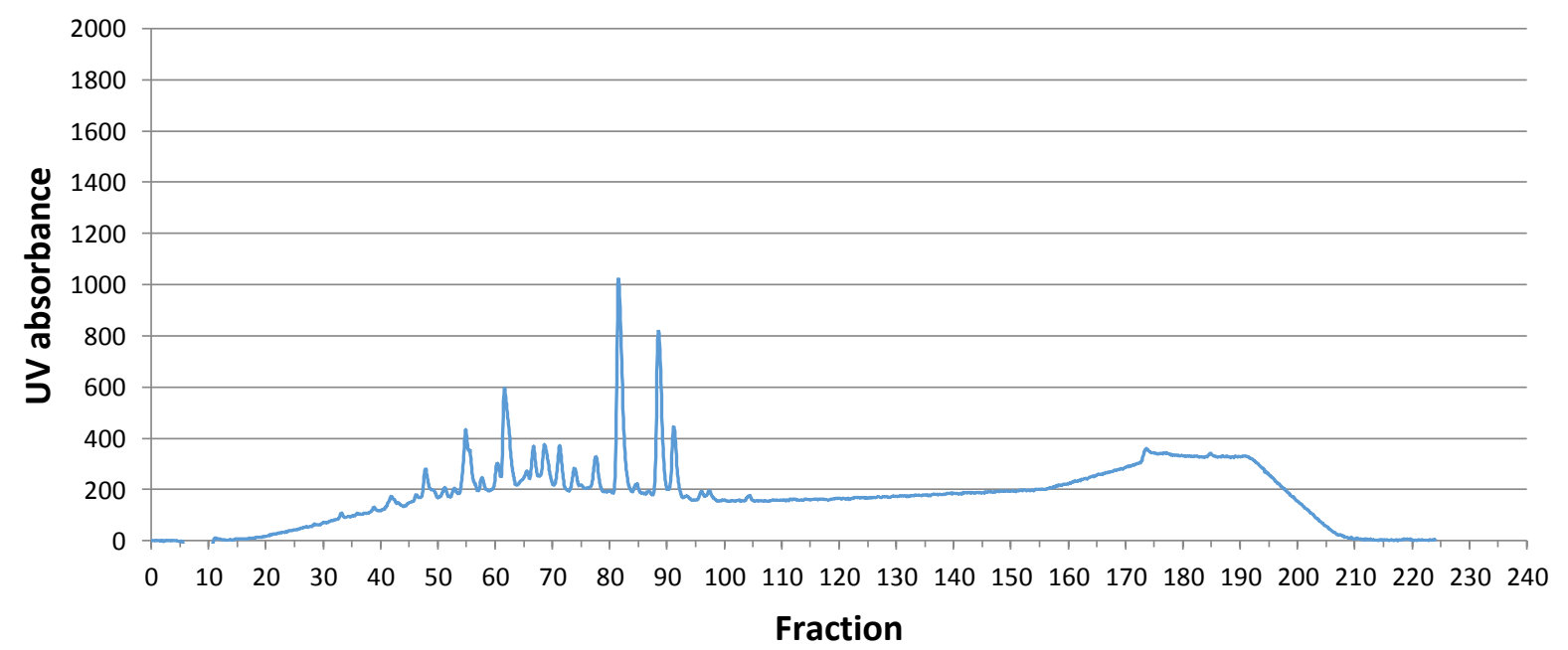

Figure 21: UV trace of the RP separation of ICAT labelled peptides from Experiment 2a using the TEMPO LC-spotter. 
instead of a gradual change from $0 \%$ to $80 \%$. The changes generated a wider peptide elution range from fractions 40 to 100 (Fig. 21).

MS and MS/MS of the 224 LC fractions led to identification of 56 MS ions matching to 11 putative ICAT-labelled peptides from ten proteins (Table 4). Titin was identified with two matching peptides. Only two proteins, myotonin protein kinase and von Willebrand factor A domain-containing protein 3A, were quantified. Myotonin-protein kinase showed a ratio near unity, while the ratio of von Willebrand factor A domain-containing protein $3 \mathrm{~A}$ was 40.6 , indicating a strong increase following GTX treatment. The peptides of the other identified proteins, phosphoglycerate kinase, acidic leucine-rich nuclear phosphoprotein, titin, vacuolar protein sorting-associated protein 13B, pleckstrin homology domain-containing family $M$ member 2, uncharacterized protein (J3QRJO), anaphase-promoting complex subunit 4 and peptidyl-prolyl cis-trans isomerase $G$, had standards errors $>0.1$ leading to exclusion from the quantitation.

Table 4: List of identified proteins, accession numbers and determined ratios from Experiment $2 a$.

\begin{tabular}{|c|c|c|c|c|c|}
\hline & Protein description & $\begin{array}{l}\text { Uniprot } \\
\text { accession \# }\end{array}$ & Score $^{1}$ & $\begin{array}{l}\text { Ratio Light/ } \\
\text { Heavy }\end{array}$ & Sequence \\
\hline 1 & $\begin{array}{l}\text { Phosphoglycerate } \\
\text { kinase }\end{array}$ & B7Z7A9 & 59 & $\begin{array}{l}\text { No } \\
\text { quantificati } \\
\text { on }^{3}\end{array}$ & ACANPAAGSVILLENLR \\
\hline 2 & $\begin{array}{l}\text { Acidic leucine-rich } \\
\text { nuclear } \\
\text { phosphoprotein } 32 \\
\text { family member A }\end{array}$ & HoYN26 & 32 & $\begin{array}{l}\text { No } \\
\text { quantificati } \\
\text { on }^{3}\end{array}$ & SLDLFNCEVTNLNDYR \\
\hline 3 & Titin & Q8WZ42-5 & 19 & $\begin{array}{l}\text { No } \\
\text { quantificati } \\
\text { on }^{3}\end{array}$ & $\begin{array}{l}\text { NVDSVVNGTCR, } \\
\text { VLDSPGPCGK }\end{array}$ \\
\hline 4 & $\begin{array}{l}\text { Vacuolar protein } \\
\text { sorting-associated } \\
\text { protein } 13 \mathrm{~B}\end{array}$ & Q7Z7G8 & 19 & $\begin{array}{l}\text { No } \\
\text { quantificati } \\
\text { on }\end{array}$ & AMLNISESCR \\
\hline 5 & $\begin{array}{l}\text { Pleckstrin homology } \\
\text { domain-containing } \\
\text { family M member } 2\end{array}$ & Q5VVD7 & 19 & $\begin{array}{l}\text { No } \\
\text { quantificati } \\
\text { on }\end{array}$ & TCFVVLSNGILYQYPDR \\
\hline 6 & $\begin{array}{l}\text { Myotonin-protein } \\
\text { kinase }\end{array}$ & MoR333 & 17 & $0.90^{2}$ & GEVSCFR \\
\hline 7 & $\begin{array}{l}\text { Uncharacterized } \\
\text { protein }\end{array}$ & J3QRJO & 16 & $\begin{array}{l}\text { No } \\
\text { quantificati } \\
\text { on }^{3}\end{array}$ & CSGGAGAVLR \\
\hline 8 & $\begin{array}{l}\text { Anaphase-promoting } \\
\text { complex subunit } 4\end{array}$ & E9PCR4 & 15 & $\begin{array}{l}\text { No } \\
\text { quantificati } \\
\text { on }\end{array}$ & SMNQAICIPLYR \\
\hline
\end{tabular}




\begin{tabular}{llllll}
\hline Protein description & $\begin{array}{l}\text { Uniprot } \\
\text { accession \# }\end{array}$ & Score $^{1}$ & $\begin{array}{l}\text { Ratio Light/ } \\
\text { Heavy }\end{array}$ & Sequence \\
\hline $9 \quad \begin{array}{l}\text { Peptidyl-prolyl cis-trans } \\
\text { isomerase G }\end{array}$ & C9JM79 & 15 & $\begin{array}{l}\text { No } \\
\text { quantificati } \\
\text { on }^{3}\end{array}$ & MPGLSCGGGR \\
$10 \quad \begin{array}{l}\text { von Willebrand factor A } \\
\text { domain-containing } \\
\text { protein 3A }\end{array}$ & $\mathrm{A}^{2} \mathrm{NCl} 4$ & 14 & $40.6^{2}$ & VCILLDTSGSMGPYLQQVK \\
$\begin{array}{l}{ }^{1} \text { Protein score calculated by Mascot } \\
{ }^{2} \text { based on one identified peptide }\end{array}$ & & & & \\
${ }^{3}$ rejected because the standard error was above the threshold of 0.1 &
\end{tabular}




\subsubsection{ICAT Experiment Two (2b): Comparison of heavy- and light-labelled control cells}

HL-60 cells were processed in the same manner as for experiment 2a. Both samples contained untreated cells only as indicated in Table 2. The LC method was retained as Experiment No. 2. The UV trace showed a similar peptide elution profile as in Experiment No. 2A with a higher peak intensity (Fig. 22). Overall, 224 LC fractions were collected.

MADLI MS of the sample eluted from the avidin column was used to identify putative peptides and ICAT pairs. In total, ten putative ICAT pairs were identified (Fig. 23). Seven of the ten pairs were also present in Experiment 2a: 932/941, 1051/1060, 1153/1162, 1195/1204, 1210/1219, 1566/1575, 1578/1587 and 1712/1721.

MS and MS/MS of the fractions resulted in the identification of 44 MS ions matching to 12 putative ICAT-labelled peptides from twelve proteins (Table 5). Triosephosphate isomerase was identified with two peptides. Four of the twelve peptides were accepted for quantification and had ratio ranging from 0.0003 to 40.6. Fructose-bisphosphate aldolase A showed a ratio near unity. Two other peptides, trafficking protein particle complex subunit 1 and LIM and calponin homology domainscontaining protein 1 , had a ratio $<1$ indicating a decrease in the heavy-labelled sample or an increase in the light-labelled sample. Von Willebrandfactor A domain-containing protein $3 \mathrm{~A}$ was identified with a ratio of 52.01 , indicating an increase in the heavy sample or an decrease in the light sample. The remaining peptides, phosphoglycerate kinase, triosephosphate isomerase, uncharacterized protein C40rf50, zinc finger protein 502, glyceraldehyde-3-phosphate dehydrogenase, mitogen-activated protein kinase kinase kinase 3 and ras GTPase-activating protein 1, had a SE of above 0.1 leading to exclusion from the quantitation. 


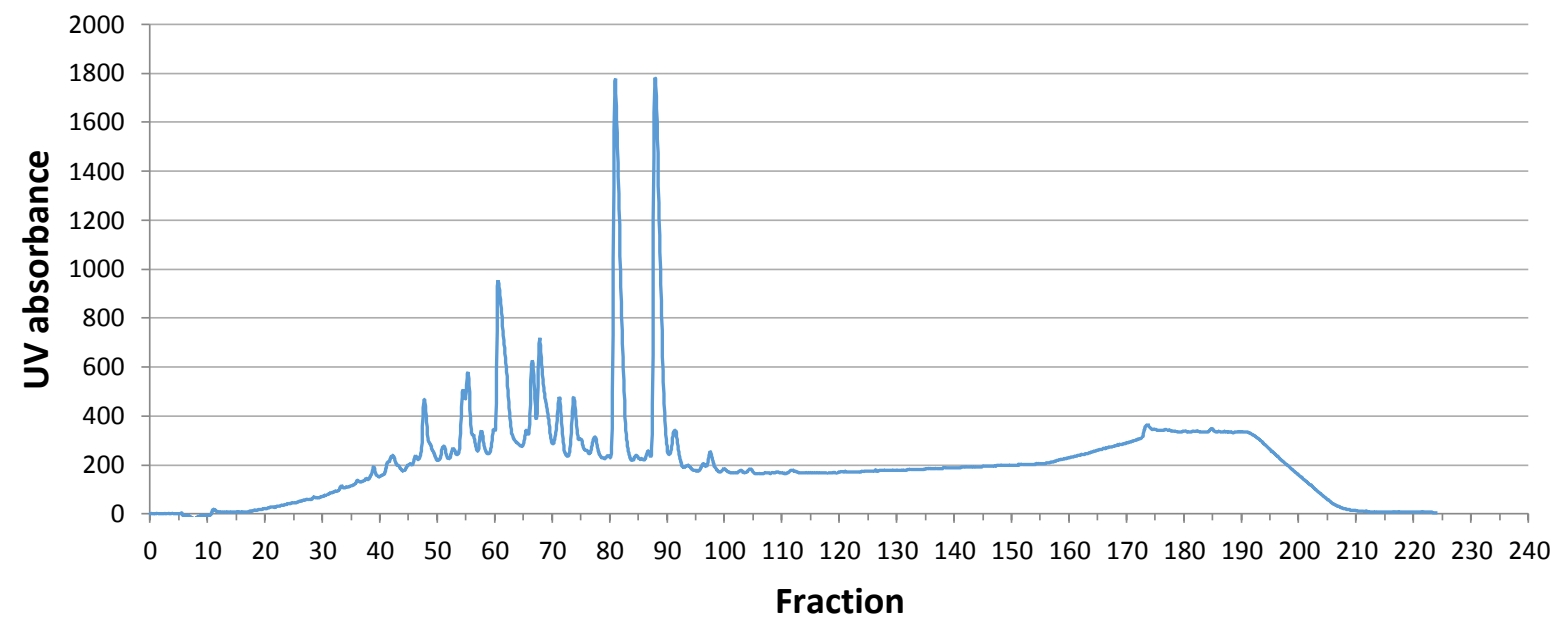

Figure 22: UV trace of the RP separation of ICAT labelled peptides from Experiment 2b using the TEMPO LC-spotter.

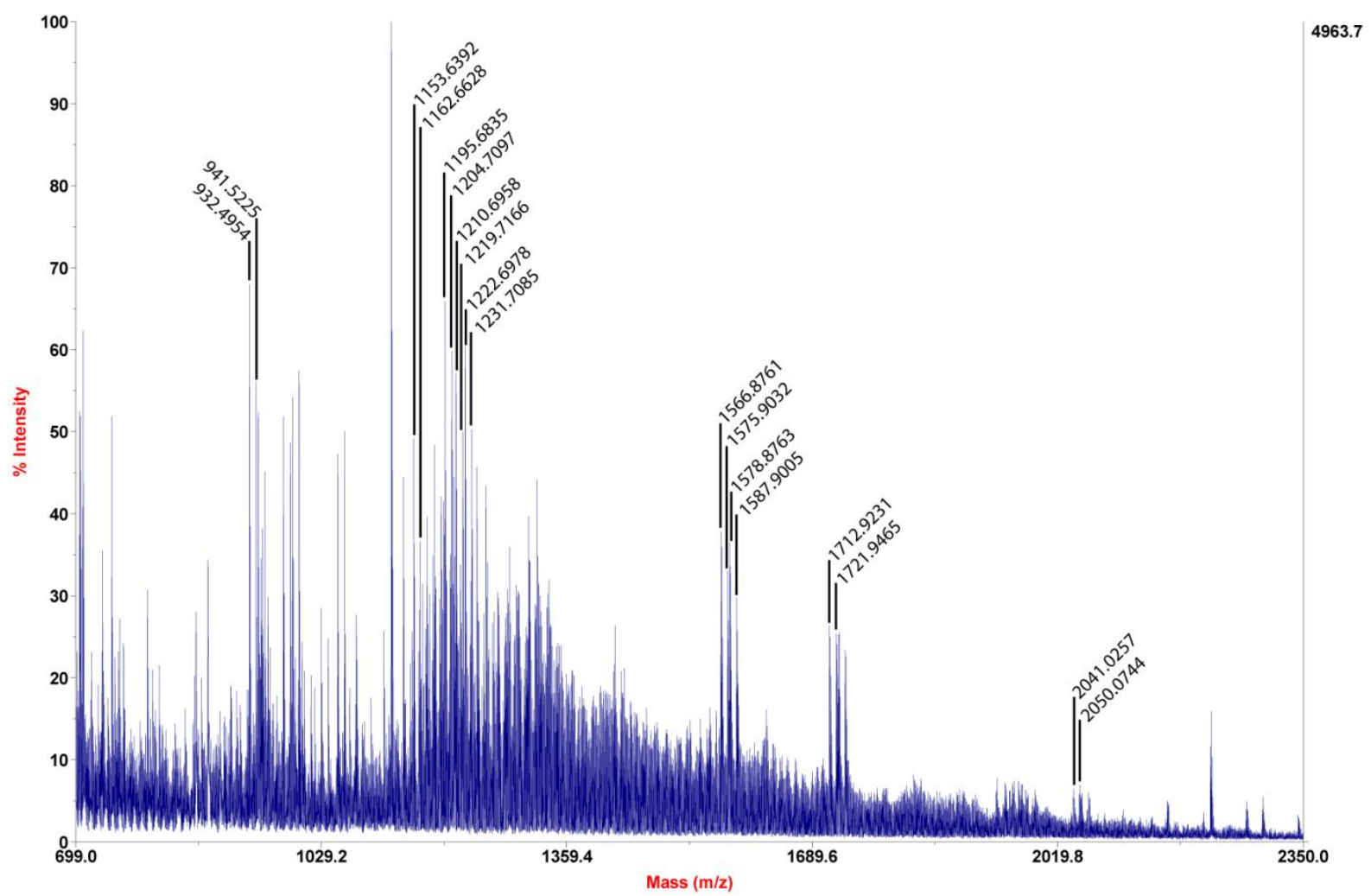

Figure 23: MS spectra of ICAT labelled peptides from Experiment 2b prior to RP-LC fractionationing. 
Table 5: List of identified proteins, accession numbers and determined ratios from Experiment $2 \mathrm{~b}$.

\begin{tabular}{|c|c|c|c|c|c|}
\hline & Protein description & $\begin{array}{l}\text { Uniprot } \\
\text { accession } \\
\#\end{array}$ & Score $^{1}$ & $\begin{array}{l}\text { Ratio } \\
\text { Light/ } \\
\text { Heavy } \\
\end{array}$ & Sequence \\
\hline 1 & $\begin{array}{l}\text { Phosphoglycerate } \\
\text { kinase }\end{array}$ & B7Z7A9 & 82 & $\begin{array}{l}\text { No } \\
\text { quantificat } \\
\text { ion }^{3}\end{array}$ & ACANPAAGSVILLENLR \\
\hline 2 & $\begin{array}{l}\text { Triosephosphate } \\
\text { isomerase }\end{array}$ & P60174 & 35 & $\begin{array}{l}\text { No } \\
\text { quantificat } \\
\text { ion }\end{array}$ & $\begin{array}{l}\text { VPADTEVVCAPPTAYIDFAR, } \\
\text { VAHALAEGLGVIACIGEK }\end{array}$ \\
\hline 3 & $\begin{array}{l}\text { Fructose- } \\
\text { bisphosphate } \\
\text { aldolase A }\end{array}$ & $\mathrm{H} 3 \mathrm{BMQ} 8$ & 27 & $0.93^{2}$ & VNPCIGGVILFHETLYQK \\
\hline 4 & $\begin{array}{l}\text { Uncharacterized } \\
\text { protein C40rf50 }\end{array}$ & E9PNW5 & 21 & $\begin{array}{l}\text { No } \\
\text { quantificat } \\
\text { ion }\end{array}$ & CSVAQGQALSSLSNGPMLR \\
\hline 5 & $\begin{array}{l}\text { Zinc finger protein } \\
502\end{array}$ & Q8TBZ5 & 18 & $\begin{array}{l}\text { No } \\
\text { quantificat } \\
\text { ion }^{3}\end{array}$ & YACEGMKENSPR \\
\hline 6 & $\begin{array}{l}\text { Glyceraldehyde-3- } \\
\text { phosphate } \\
\text { dehydrogenase }\end{array}$ & E7EUT5 & 17 & $\begin{array}{l}\text { No } \\
\text { quantificat } \\
\text { ion }\end{array}$ & VPTANVSVVDLTCR \\
\hline 7 & $\begin{array}{l}\text { von Willebrand factor } \\
\text { A domain-containing } \\
\text { protein } 3 A\end{array}$ & $\mathrm{~A} 6 \mathrm{NCl}_{4}$ & 17 & $52.01^{2}$ & VCILLDTSGSMGPYLQQVK \\
\hline 8 & $\begin{array}{l}\text { Trafficking protein } \\
\text { particle complex } \\
\text { subunit } 1\end{array}$ & F8WE24 & 17 & $0.0003^{2}$ & CVVLSDPLK \\
\hline 9 & $\begin{array}{l}\text { Mitogen-activated } \\
\text { protein kinase kinase } \\
\text { kinase } 3\end{array}$ & $\mathrm{~J}_{3} \mathrm{KRN}_{4}$ & 16 & $\begin{array}{l}\text { No } \\
\text { quantificat } \\
\text { ion }^{3}\end{array}$ & LQTICMSGTGMR \\
\hline 10 & $\begin{array}{l}\text { Ras GTPase- } \\
\text { activating protein } 1\end{array}$ & B4DTL2 & 16 & $\begin{array}{l}\text { No } \\
\text { quantificat } \\
\text { ion }\end{array}$ & DLAALHEICVAHSDELR \\
\hline 11 & $\begin{array}{l}\text { LIM and calponin } \\
\text { homology domains- } \\
\text { containing protein } 1\end{array}$ & G5EA03 & 14 & $0.07^{2}$ & NQGHTEEVKLIVTCNMR \\
\hline
\end{tabular}




\subsubsection{Comparison of all ICAT experiments}

The precursor masses of the identified peptides of all ICAT experiments have been compared (Table 6). The highlighted matches are glyceraldehyde-3-phosphate dehydrogenase (green) and von Willebrand factor A domain-containing protein $3 \mathrm{~A}$ (gray).

Table 6: List of MS ions from identified peptides of the different experiments. Different colors highlighting similar MS ions between the experiments.

\section{Experiment}

No. $1 \quad$ No. $2 a \quad$ No. $2 b$

\begin{tabular}{rrr}
\hline 1347.67 & 1024.57 & 1209.326 \\
1417.681 & 1126.57 & 1533.85 \\
1496.74 & 1186.49 & 1627.851 \\
\hline 1529.75 & 1359.66 & 1700.904 \\
\hline 1548.77 & 1399.651 & 1939.015 \\
\hline 1664.79 & 1635.8 & 2128.125 \\
\hline 1700.832 & 1938.95 & 2146.083 \\
\hline 1709.865 & 2142.94 & 2208.175 \\
\hline 1768.79 & 2214.942 & 2267.163 \\
\hline 1784.77 & 2295.045 & 2295.199 \\
\hline 1992.97 & & 2362.193 \\
\hline
\end{tabular}

\subsubsection{Alternative Mascot searches}

The Mascot algorithm searches only for cys-containing heavy and light peptide pairs with 9 Da mass differences, when the ICAT quantitation method is selected. Alternative searches were therefore performed with the data from the second experiment to identify possible peptides that did not contain cys residues. Possibilities that were examined included peptides without cys that were retained after avidin cleanup, or ICAT peptides without a 9 Da pair that might reflect inability to label a completely modified cysteine in one treatment group. Four different search routines 
were used; no ICAT, both ICAT reagents as variable modifications, ICAT reagent light as fixed modification with ICAT reagent heavy as variable modification and ICAT reagent heavy as fixed modification with ICAT reagent light as variable modification. The search allowing for both ICAT reagents as variable modifications identified some peptides with an ICAT tags in line with the original search. These peptides were identified as phosphoglycerate kinase, acidic leucine-rich nuclear phosphoprotein 32 family member $B$ and fructose-bisphosphate aldolase. Two peptides from the original search gave different matches; the titin peptide (NVDSVVNGTCR, score 19) now matched fructosebisphosphate aldolase (PNMVTPGHACTQK, score 2), while the pleckstrin homology domain protein (TCFVVLSNGILYQYPDR, score 19) now matched actin (DLYANTVLSGGTTMYPGIADR, score 150); both without an ICAT tag.

The results from the search without ICAT as a modification did not give additional information and are not shown. In a further comparison between the different searches each precursor mass leading to a protein identification for the quantitative search was matched with the peptide sequence and a peptide score from the search with ICAT as a variable modification (Tab. 7). A higher peptide score for a peptide without an ICAT modification was assumed as an indication of a carry-over of unlabelled peptides. In Experiment $2 \mathrm{a}$ only one ICAT pair could be fully confirmed (highlighted in green); phosphoglycerate kinase. Two peptides fulfilled the requirements to be considered as GTX-induced modifications (highlighted in gray): acidic leucine-rich nuclear phosphoprotein 32 family member A and von Willebrand factor A domain-containing protein $3 \mathrm{~A}$. The requirements were the loss of the heavy ICAT partner of the pair, a high score for the identified light ICAT-labelled peptide and the presence of the complete ICAT pair in Experiment 2b. Cytoplasmic Actin 1 was identified with a high score as an unlabelled peptide (highlighted in blue), and therefore might be contamination of the avidin-selected sample by a non-cys peptide from this high abundance protein. Three peptides were marked as 'unknown' (highlighted in orange) because the identification score of the labelled peptide was higher than the one for an unlabelled peptide, but the ICAT partner was not present either in Experiment $2 \mathrm{a}$ or $2 \mathrm{~b}$. This was done to differentiate them from possible GTX-modifed peptides, because in the case of a cysteine modification both ICAT-labelled peptides should be at least present in experiment $2 \mathrm{~b}$. 
This left four ICAT pairs unclassified (not highlighted). Two of these four (1399.6510 m/z and $1126.5650 \mathrm{~m} / \mathrm{z}$ ) were identified as a labelled peptide and the matching precursor $(1391.4681 \mathrm{~m} / \mathrm{z}$ and 1117.5654$)$ as an unlabelled one, which could indicate an unlabelled peptide of the same mass $(1391.4681 \mathrm{~m} / \mathrm{z}$ and 1117.5654$)$ masked the labelled partner or the labelled peptide $(1399.6510 \mathrm{~m} / \mathrm{z}$ and $1126.5650 \mathrm{~m} / \mathrm{z}$ ) was misidentified. One of the four $(1024.9420 \mathrm{~m} / \mathrm{z})$ was identified as a labelled peptide missing an ICAT partner but was not identified in Experiment 2b. This might be a GTX-targeted protein but the matching partner (1033.x m/z) was identified differently in Experiment 2b. The remaining ICAT pair (1208.2160 m/z, $1208.2270 \mathrm{~m} / \mathrm{z}$ and $1199.8373 \mathrm{~m} / \mathrm{z}, 1199.5764 \mathrm{~m} / \mathrm{z}, 1199.5764 \mathrm{~m} / \mathrm{z}$ ) showed a positive identification of one ICAT-labelled peptide $(1208.2160 \mathrm{~m} / \mathrm{z}$, ICAT H) but a peptide with a very similar mass was identified differently $(1208.2270 \mathrm{~m} / \mathrm{z})$. Additionally, all three putative ICAT partner (1199.8373 m/z, $1199.5764 \mathrm{~m} / \mathrm{z}, 1199.5764 \mathrm{~m} / \mathrm{z})$ were identified differently. 
Table 7: Comparative table of precursor masses from Exp. 2a with possible ICAT pair matches, the Mascot score from the quantitative search and a Mascot search with ICAT as variable modifications, the light to heavy ratio, the presence in pre and post avidin spectra and in Experiment $2 \mathrm{~b}$, the assigned peptide sequence and the matching protein. Green indicates a confirmed ICAT pair, gray a possible GTX-induced cys modification, orange an unknown labeling status and blue a possible contamination. The peptide sequence is given from the identification with the highest score. In case of the same score the peptide sequence from Mascot search with ICAT as variable modification is given in breakets.

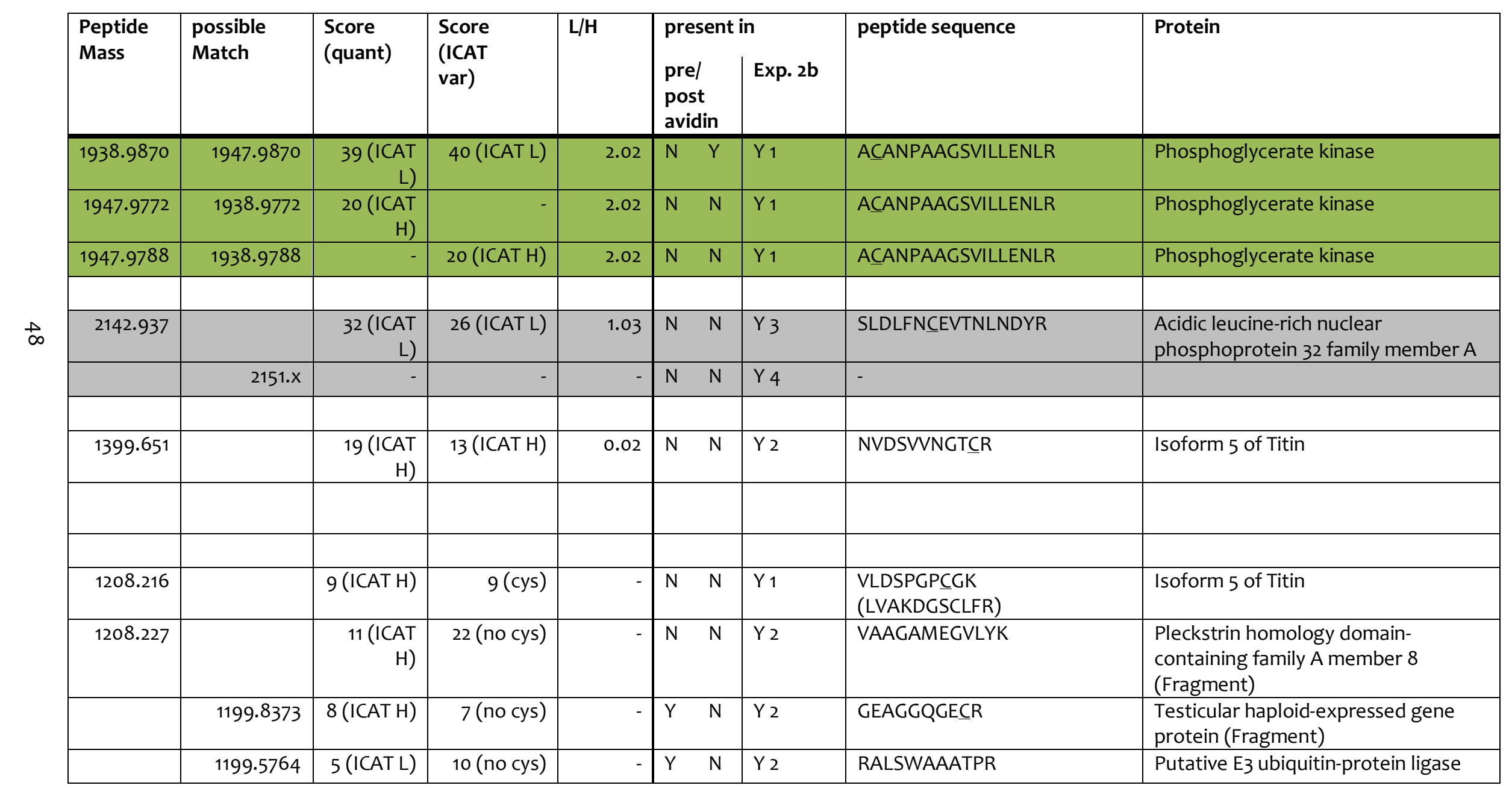




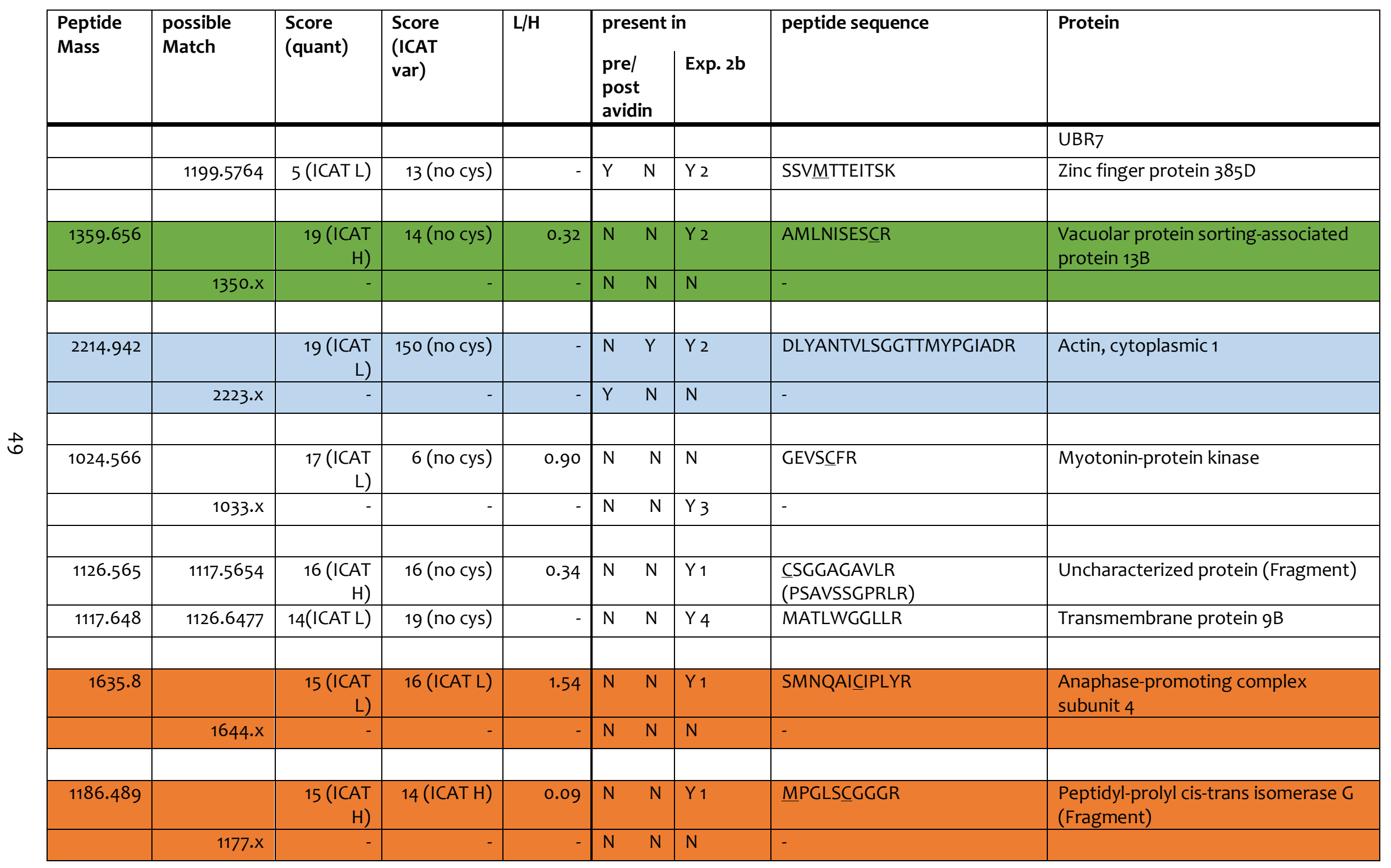




\begin{tabular}{|c|c|c|c|c|c|c|c|c|}
\hline $\begin{array}{l}\text { Peptide } \\
\text { Mass }\end{array}$ & $\begin{array}{l}\text { possible } \\
\text { Match }\end{array}$ & $\begin{array}{l}\text { Score } \\
\text { (quant) }\end{array}$ & $\begin{array}{l}\text { Score } \\
\text { (ICAT } \\
\text { var) }\end{array}$ & L/H & $\begin{array}{l}\text { present } \\
\text { pre/ } \\
\text { post } \\
\text { avidin }\end{array}$ & $\begin{array}{l}\text { Exp. 2b } \\
\text { Expla }\end{array}$ & peptide sequence & Protein \\
\hline \multirow[t]{2}{*}{2295.045} & & $\begin{array}{r}14 \text { (ICAT } \\
\mathrm{L})\end{array}$ & 15 (ICAT L) & $40.61^{1}$ & $\mathrm{~N} \quad \mathrm{Y}$ & $Y_{1}$ & VCILLDTSGSMGPYLQQVK & $\begin{array}{l}\text { von Willebrand factor A domain- } \\
\text { containing protein } 3 \mathrm{~A}\end{array}$ \\
\hline & $2304 \cdot x$ & - & - & - & $\mathrm{N} \quad \mathrm{N}$ & $\mathrm{Y} 2$ & - & \\
\hline
\end{tabular}


The same searches were performed for Experiment $2 b$ (Table 8). Three potential ICAT pairs were identified (highlighted in green); phosphoglycerate kinase, triosephosphate isomerase and glyceraldehyde-3-phosphate dehydrogenase. Six of the nine remaining peptides where identified as labelled peptide but the ICAT partner was missing, so they were considered as 'unknown' (highlighted in orange) because the expected ICAT patner should at least be detected as MS ion. From the three remaining peptides, two peptides ( $2146.0825 \mathrm{~m} / \mathrm{z}$ and $2295.1987 \mathrm{~m} / \mathrm{z}$ ) were identified with an ICAT label but the potential partners $(2155.1621 \mathrm{~m} / \mathrm{z}$ and $2304.1170 \mathrm{~m} / \mathrm{z}$ ) were identified as unlabelled peptides. From the remaining peptide $(2128.1246 \mathrm{~m} / \mathrm{z})$ the putative partner $(2119.0389 \mathrm{~m} / \mathrm{z})$ was identified as a labelled and as an unlabelled peptide with the same mascot score. 
Table 8: Comparative table of precursor masses from Experiment $2 \mathrm{~b}$ with possible ICAT pair matches, the mascot score from the quantitative search and a mascot search with ICAT as variable modifications, the light to heavy ratio, the presence in pre- and post-avidin spectra and in Experiment 2a, the assigned peptide sequence and the matching protein. Green indicates a confirmed ICAT pair, and orange an unknown labeling status. The peptide sequence is given from the identification with the highest score. In case of the same score the peptide sequence from Mascot search with ICAT as variable modification is given in breakets.

\begin{tabular}{|c|c|c|c|c|c|c|c|c|}
\hline $\begin{array}{l}\text { Peptide } \\
\text { Mass }\end{array}$ & $\begin{array}{l}\text { possible } \\
\text { Match }\end{array}$ & $\begin{array}{l}\text { Score } \\
\text { (quant) }\end{array}$ & $\begin{array}{l}\text { Score } \\
\text { (ICAT } \\
\text { var) }\end{array}$ & $\mathrm{L} / \mathrm{H}$ & $\begin{array}{l}\text { present } \\
\text { pre/ } \\
\text { post } \\
\text { avidin }\end{array}$ & Exp. $2 a$ & peptide sequence & Protein \\
\hline 1939.0152 & 1948.0258 & 70 (ICAT L) & 70 (ICAT L) & 1.67 & $\mathrm{~N} \quad \mathrm{~N}$ & $Y_{1}$ & ACANPAAGSVILLENLR & Phosphoglycerate kinase \\
\hline 1948.0258 & 1939.0152 & 7 (ICAT H) & 7 (ICAT H) & 1.67 & $\mathrm{~N} \quad \mathrm{~N}$ & $\mathrm{Y} 2$ & SDLNLTRGVGWTPPGSYK & Phosphoglycerate kinase \\
\hline \multirow[t]{2}{*}{1987.0510} & & $17($ ICAT H) & 17 (ICAT H) & & $\mathrm{N} \quad \mathrm{N}$ & $\mathrm{N}$ & VAHALAEGLGVIACIGEK & Triosephosphate isomerase \\
\hline & 1978.x & - & - & & $\mathrm{N} N$ & Y 4 & - & \\
\hline 2362.1932 & 2371.2309 & 35 (ICAT L) & 35 (ICAT L) & 0.06 & $\mathrm{~N} \quad \mathrm{~N}$ & $\mathrm{~N}$ & VPADTEVVCAPPTAYIDFAR & Triosephosphate isomerase \\
\hline 2371.2309 & 2362.1932 & 12 (ICAT H) & 12 (ICAT H) & 0.06 & $\mathrm{~N} \quad \mathrm{~N}$ & $\mathrm{~N}$ & VPADTEVVCAPPTAYIDFAR & Triosephosphate isomerase \\
\hline \multirow[t]{2}{*}{2267.2039} & & 27 (ICAT H) & 27 (ICAT H) & 0.93 & $\mathrm{~N} \quad \mathrm{~N}$ & $\mathrm{~N}$ & VNPCIGGVILFHETLYQK & $\begin{array}{l}\text { Fructose-bisphosphate aldolase A } \\
\text { (Fragment) }\end{array}$ \\
\hline & $2258 . x$ & - & - & 0.93 & $\mathrm{~N} \quad \mathrm{~N}$ & Y 4 & - & \\
\hline \multirow[t]{2}{*}{2146.0825} & & 21 (ICAT L) & 21 (ICAT L) & 3.54 & $\mathrm{~N} \quad \mathrm{~N}$ & $\mathrm{Y} 2$ & CSVAQGQALSSLSNGPMLR & Uncharacterized protein C40rf50 \\
\hline & 2155.1621 & 7 (ICAT H) & 8 (no cys) & 3.54 & $\mathrm{~N} \quad \mathrm{~N}$ & $Y_{3}$ & PMDDDLLKLLLPLMLQVR & $\begin{array}{l}\text { Mediator of RNA polymerase II } \\
\text { transcription subunit 12-like protein }\end{array}$ \\
\hline \multirow[t]{2}{*}{1627.8508} & & 18 (ICAT L) & 18 (ICAT L) & 1.73 & $\mathrm{~N} \quad \mathrm{Y}$ & $\mathrm{Y}_{1}$ & YACEGMKENSPR & Zinc finger protein 502 \\
\hline & $1636 . x$ & - & - & 1.73 & $\mathrm{~N} \quad \mathrm{Y}$ & $Y 2$ & - & \\
\hline
\end{tabular}




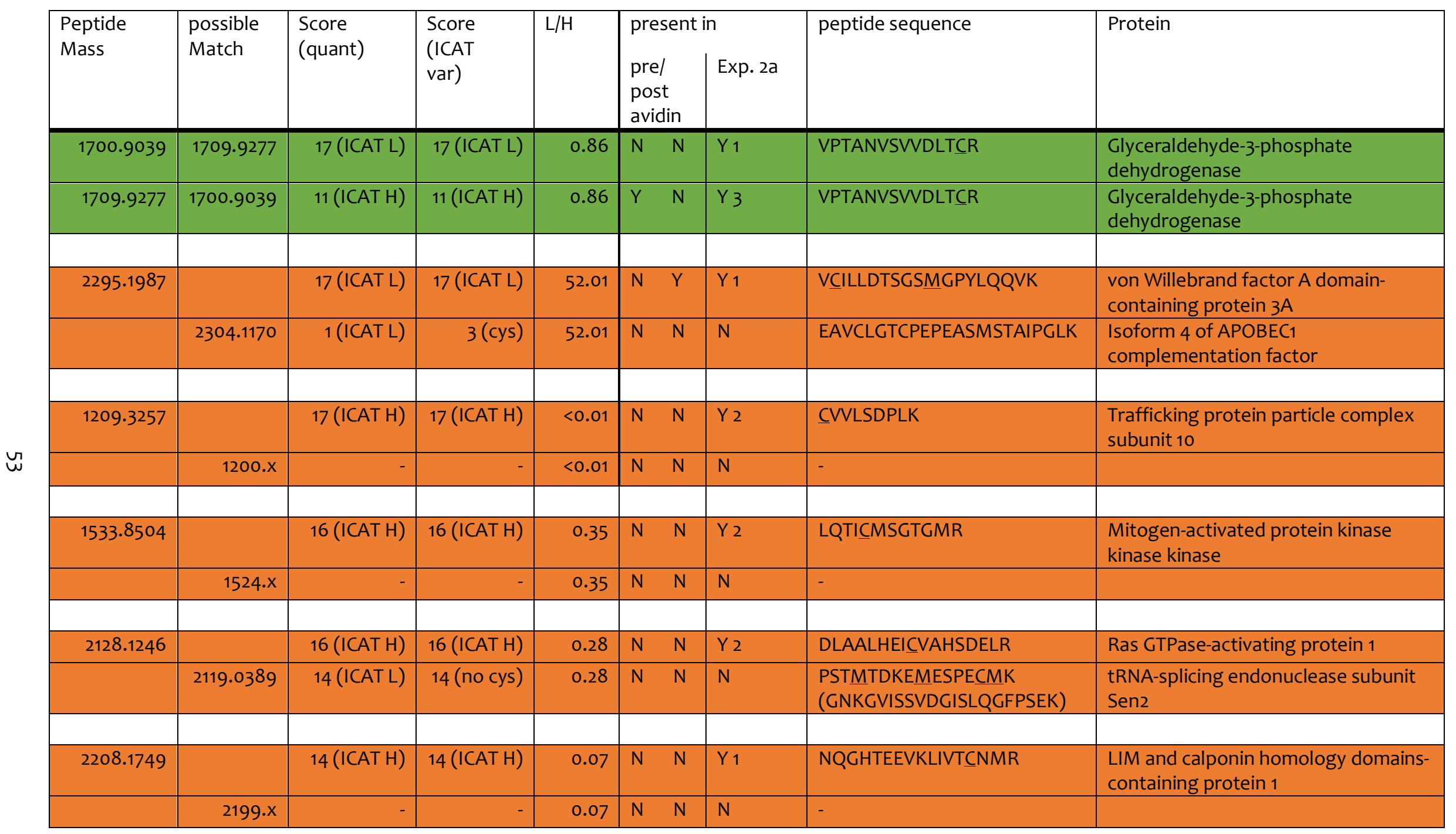




\section{Discussion}

\subsection{Cellular effects of GTX}

\subsubsection{Cell viability}

GTX affects cell viability in HL-60 cells with greater effects at $24 \mathrm{~h}$ than at 1 or $3 \mathrm{~h}$. At $24 \mathrm{~h}$ viability was affected even at the lowest tested concentrations of GTX. The results from the short exposure times ( $1 \mathrm{~h}$ and $3 \mathrm{~h}$ ) are likely to be less accurate because of direct reduction of MTT to its formazan by GTX. Yoshida et al. (2000) reported oxygendependent reduction of cytochrome $\mathrm{c}$ by GTX in isolated neutrophils. They investigated whether reduction was mediated by ROS but added catalase or superoxide dismutase failed to prevent cytochrome $c$ reduction, indicating that neither $\mathrm{H}_{2} \mathrm{O}_{2}$ nor $\mathrm{O}_{2}{ }^{-}$were involved in the reduction. Apparent reduction of MTT by GTX was only detected at the short exposure times and may have been masked by changes in cell viability at $24 \mathrm{~h}$. Further studies are needed to explore the exact conditions and mechanisms of the reaction between GTX and MTT to fully explain the results.

HL-6o cells are a promyelocytic leukemic cell line and may therefore be relevant to study of the effects of GTX on immune cells. The $\mathrm{TC}_{50}$ of $76 \mathrm{nM}$ after $24 \mathrm{~h}$ of treatment can be compared with the $\mathrm{TC}_{50}$ for lung epithelial cells $(500 \mu \mathrm{M})$ and macrophages. Alveolar macrophages are more sensitive $\left(\mathrm{TC}_{50} 30 \mathrm{nM}\right)$ to $\mathrm{GTX}$ than the HL-60 cells, which might be an evolutionary adaption of A. fumigatus as a lung pathogen (Sugui et al., 2007; Kwon-Chung and Sugui, 2009; Abad et al., 2010). This may indicate the selectiveness of GTX to immune system-related cells. However, the viability of OE4 cells (H-2d-specific CD8 ${ }^{+}$cytotoxic T lymphocyte) is only marginally affected by GTX up to $10 \mu \mathrm{M}$, although GTX inhibits the cytotoxic activity of these cells at a much lower dose (IC $C_{50}$ of $0.2 \mu \mathrm{M}$ ) (Yamada, Kataoka and Nagai, 2000).

\subsubsection{ROS production}

HL-60 cells treated with up to $10 \mu \mathrm{g} / \mathrm{ml}$ GTX did not show increased ROS production compared to untreated cells. In HepG2 cells, GTX slightly increased ROS production (Hur et al., 2008), while apoptosis in PU5-1.8 macrophages and hepatic stellate cell has been related to ROS (Suen et al., 2001; Kweon et al., 2003). This suggests that GTX may act through a variety of possible pathways which might be more or less specific. 


\subsubsection{Cell cycle analysis}

This study is one of the first to show that GTX affects the cell cycle of HL-60 cells. At a lower concentration $(0.1 \mu \mathrm{g} / \mathrm{ml})$ no effect on the cell cycle was visible, even though MTT assays showed decreased viability at the same concentration. An increase in concentration to $1 \mu \mathrm{g} / \mathrm{ml} \mathrm{GTX}$ caused a strong increase in apoptosis and a $\mathrm{G}_{1}$ arrest. $A \mathrm{G}_{1}$ block can be induced over many different pathways such as inhibition of geranylgeranyltransferase (Miquel et al., 1997), microtubule depolymerisation (Blajeski et al., 2002), DNA damage or cyclin inhibition (Resnitzky and Reed, 1995; Woo and Poon, 2003).

Sporidesmin showed a similar effect on the cell cycle in non-tumorigenic rat liver cells (Jordan and Pedersen, 1986). Here, cells treated with $0.1 \mu \mathrm{g} / \mathrm{ml}$ sporidesmin for $24 \mathrm{~h}$ showed a blocked entry into S-phase and after $48 \mathrm{~h} 95 \%$ of the cells were in $\mathrm{G}_{1}$ phase. In contrast to GTX, sporidesmin did not cause apoptosis at this concentration.

\subsubsection{Summary}

The results using HL-60 cells indicate that production of ROS is not a major effect of GTX, suggesting that the alternative hypothesis of direct modification of protein cysteines is relevant to this study.

\subsection{ICAT-labelling of BSA}

The initial evaluation of ICAT labelling using BSA showed a high rate of labelling and a high Mascot score for peptide and protein identification. Protein coverage of $41 \%$ was achieved in the sample with a one to one labelling ratio, and $45 \%$ in the sample with a one to four ratio. This was effective labelling when compared to the maximum possible coverage of $53 \%$ based on theoretical peptides with no missed cleavages. The one to four sample had a lower Mascot score, which might be due to decreased labelling at lower protein concentrations, but there was higher protein coverage in this sample due to the identification of larger peptides. Both samples had a low FDR (1.4\% and 0.4\%) which shows a robust identification of BSA. Both samples showed the expected protein ratios but the variation for individual peptides was greater, indicating that a precise determination of the protein ratio may require more than one quantified peptide. 


\subsubsection{ICAT mass spectrometry of HL-60 cell extracts}

For the assessment of cysteine modification by GTX an effective concentration was needed to get as many modifications as possible, while the cells should not be in an apoptotic state that might introduce additional changes among proteins. Therefore, the GTX treatment of HL-60 cells was at a relatively high concentration of $1 \mu \mathrm{g} / \mathrm{ml}$ but only over three hours to minimise downstream effects of apoptosis. Additionally, a short exposure time was used to minimize protein synthesis following the GTX treatment which would influence the protein ratios independent of cysteine modifications. DMEM media was chosen because it did not contain GSH which possibly would have interfered with the experiment.

ICAT was expected to be a suitable method for detection of proteins that were modified by reaction of cysteine with GTX as GTX is expected to only react with accessible surface thiol groups on proteins.

\subsubsection{ICAT Experiment One: Comparison of GTX-exposed with control cell extracts}

The analysis of the first ICAT labelling led to the identification of eight proteins, six of them with a measured $\mathrm{L} / \mathrm{H}$ ratio and two without (Table 3). The identified proteins had Mascot scores ranging from 25 to 169 based on detected labelled peptides. All proteins were identified based on one matched peptide, except for peptidyl-prolyl cis-trans isomerase which was matched with two peptides. An additional Mascot search (not shown) supported the identification of all proteins with the exception of isoform 4 of protein sidekick-2, which was identified with a marginally lower score of 23 as olfactory receptor $1 \mathrm{~L} 1$. Three of the eight proteins were identified with $\mathrm{L} / \mathrm{H}$ ratio $>1$, one with a ratio of approximately 1 and two with a ratio $<1$, while two proteins were not quantified. None of the identified proteins were one of the already known targets of GTX: ADH, GRx, CK or FTase. This is likely due to the relative low abundance of these proteins. The proteins with an indicated decrease following GTX treatment were tubulin, glyceraldehyde-3phosphate dehydrogenase and peptidyl-propyl cis-trans isomerase. This suggests that these three proteins are targeted by GTX resulting in a modification of the susceptible cysteine that prevented ICAT labelling leading to a decreased intensity in the heavy labelled, GTX-treated, sample. 
Tubulin was detected with the highest ratio, suggesting it as predominant target for GTX, but this might also be due to the high abundance of tubulin. Tubulin has been reported to have a reactive cysteine at position 12, 239 and 303 (Kim, Pannell and Sackett, 2004; Antony et al., 2014). Cysteine 12 was identified to be modified by GTX and is known to be a part of guanosine triphosphate (GTP) binding site (Luduena and Roach, 1991). A blockage of GTP binding would lead to tubulin depolymerisation (Heald and Nogales, 2002). Tubulin depolymerisation is associated with mitotic cell arrest (Blajeski et al., 2002) which is in contrast with the findings of the cell cycle analysis as GTX caused $\mathrm{G}_{1}$ arrest.

Glyceraldehyde-3-phosphate dehydrogenase has been reported to have a reactive cysteine at position 151 (Perham, 1969; Banas, Banas and Wolny, 1976), but the ICAT labelled cysteine was at position 247. This suggests that cysteine 247 is also a reactive cysteine but the impact of its modification is yet to be determined.

Peptidyl-propyl cis-trans isomerase has four cysteinyl residues from which one (cysteine 62) was detected as target for GTX. None of the cysteines seems to have an essential function (Liu et al., 1990). But a different peptidyl-propyl cis-trans isomerase, cyclophilin D, seems to be affected in function by GTX binding (Wright et al., 2001).

Serum albumin and heterogeneous nuclear ribonucleoprotein A1 showed a ratio indicating a higher abundance in the GTX-treated sample than in the control. An explanation could be increased protein synthesis following GTX treatment, which is unlikely because of the short exposure time, or that GTX, possibly intracellular GTX dithiol, acted as a reducing agent and reduced the disulfides into thiols rendering them accessible for ICAT labelling. This would then raise the questions, why are only these two proteins affected and are all ratios shifted towards the heavy label?

In the monitoring step prior to LC fractionation, ten putative ICAT pairs could be identified from which none could be matched to a peptide sequence with a reasonable Mascot score later in the MS/MS analysis (Fig. 17). Four pairs were not identified because their mass after cleavage was below the set mass detection minimum of $700 \mathrm{~m} / \mathrm{z}$. Four of the putative ICAT pairs with a mass above $1380.34 \mathrm{~m} / \mathrm{z}$ were identified as MS ions but could not be matched to a peptide sequence. The remaining pair was not present as MS ions. Detection of these additional apparent ICAT pairs by direct MALDI of the avidin- 
captured extract indicated that only a subset of the ICAT-labelled peptides was detected during analysis of the TEMPO fractions.

\subsubsection{ICAT Experiment Two (2a): Comparison of GTX-exposed with control cell extracts}

Ten potential ICAT-labelled proteins were identified in the second comparison of HL-60 proteins from GTX and control cells, nine with one matching peptide, plus titin which was identified from two peptides (Table 4). From these eleven peptides only two were quantified as ICAT pairs in the Mascot analysis. The ratio of myotonin-protein kinase was 0.9 , near unity, but von Willebrand factor $A$ domain-containing protein $3 \mathrm{~A}$ ratio was approximately 40 indicating a higher abundance in the GTX-treated sample than in the control. None of the proteins identified in Experiment One was re-identified in this experiment, but two proteins were from the same protein family (peptidyl-prolyl cistrans isomerase from Experiment One and peptidyl-prolyl cis-trans isomerase $G$ from Experiment Two). Increased labelling of the von Willebrand factor protein might be due to GTX dithiol mediated reduction of a susceptible cysteine in this protein.

Subsequent Mascot searches (Table 7) using ICAT as a variable modification supported the identification of only nine of the ten proteins, as the pleckstrin homology domain-protein was alternatively identified as actin without an ICAT label at a much greater score (150 compared to 19). To examine why only two of the proteins were quantified, a search for 9 Da putative ICAT pairs showed that both ICAT-labelled peptides were identified only for phosphoglycerate kinase. However, other possible proteins could be identified in which the heavy ICAT-labelled peptide was not present in Experiment Two but was detected in the control labelling experiment, Experiment Three (2b). These proteins, acidic leucine-rich nuclear phosphoprotein 32 family member $A$ and von Willebrand factor $\mathrm{A}$ domain-containing protein $3 \mathrm{~A}$, were therefor considered as putative targets of GTX due to the complete loss of the heavy label. This contrasts with the ratio determined for von Willebrand factor $A$ domain-containing protein $3 \mathrm{~A}$. Three other proteins, vacuolar protein sorting-associated protein 13B, anaphase-promoting complex subunit 4 and peptidyl-prolyl cis-trans isomerase $G$ (Fragment) were identified in both experiments (Two and Three) without a heavy label.

Eight putative ICAT pairs were detected by direct MALDI of the avidin-captured peptides prior to LC (Fig. 20), but only one matched a protein that was identified from 
the LC fractions: the putative ICAT pair at m/z 2040/2049 matched to vacuolar protein sorting-associated protein 13B. However, the peptide leading to the identification of the protein was detected with only a heavy ICAT label. This could either mean that the peptide was falsely identified or that there is another peptide with the same $\mathrm{m} / \mathrm{z}$ containing a light ICAT label. The results again suggested that more ICAT pairs were present than those identified after offline LC MALDI, and there were many unidentified MS ions.

\subsubsection{ICAT Experiment Three (2b): Comparison of light and heavy labelled control cell extracts}

Experiment Three was planned to evaluate the ICAT procedure using light and heavy labelling of a control cell extract. It was carried out and processed as the same time as Experiment Two using the same batch of ICAT reagents.

Eleven proteins were identified based on twelve peptides. Triosephosphate isomerase was identified by two matching peptides (Table 5). Four of the eleven proteins were quantified: one with a label ratio near unity (fructose-bisphosphate aldolase $A$ ), two with higher abundance in the heavy-labeled sample (trafficking protein particle complex subunit 1 and LIM and calponin homology domains-containing protein 1), and one with a higher abundance in the heavy labeled sample (von Willebrand factor A domaincontaining protein $3 \mathrm{~A}$ ). The presence of von Willebrand factor $A$ domain-containing protein $3 \mathrm{~A}$ in the control experiments with a ratio similar to Experiment Two contradicts the former suggestion that change was due to GTX-mediated reduction. The second high ratio variation raises additional questions about the basis of detected change.

The additional Mascot searches supported the identification of three proteins by identifying both ICAT-labelled peptides (Table 8). These three were phosphoglycerate kinase, triosephosphate isomerase (peptide VPADTEVVCAPPTAYIDFAR) and glyceraldehyde-3-phosphate dehydrogenase. From the other proteins only one of the ICAT-labelled peptides was identified. The other putative peptide was either not present or identified as a peptide with a different peptide sequence matching a different protein. The previously identified putative ICAT pairs from the MS prior to LC (Fig. 23) did not match with the identified peptides. All of the putative pairs were present in the following MS/MS analysis as MS ions, but no peptide sequence could be identified. 


\subsubsection{ICAT performance}

The number of MS ions matched to a peptide sequence and subsequent protein identification was low in all three HL-60 experiments compared to the BSA experiments. From the BSA samples 661 and 294 MS ions (1-to-1 sample and 1-to-4 sample, respectively) were matched to a peptide sequence, while only 56 to 35 MS ions of the HL-60 ICAT samples were matched to peptide sequences. One explanation could be the higher complexity of the HL-60 samples resulting in a lower amount of each protein for labelling. Exclusion of the standard reduction step in the ICAT protocol may also have affected labelling. Although it is necessary to exclude reduction for detection of modified cysteines, the peptide pool is decreased from all cys-containing peptides to only reactive and accessible cys-containing sequences. Additionally, it appeared that some non cyscontaining and unlabelled cys-containig peptides were retained after avidin capture of labelled cell extracts suggesting contamination possibly due to high abundance proteins including actin.

Potential optimization steps include an additional fractionation using the strong ion exchange column, and an increased initial sample amount to compensate for the decreased possible peptide set. Prefractionation, by decreasing complexity, would increase resolution of the sample which would be beneficial for low abundance proteins and may assist purification as a lower protein amount would be loaded on each avidin column. This might also help reduce contamination with unlabelled high abundance proteins. An increased sample amount might also increase the MS/MS quality as more of each specific peptide would be present, but an increase needs to be carefully considered as the ICAT reagent is designed to label a certain amount of protein. An excess of cysteine compared to ICAT reagent may result in sub-minimal labelling that could compromise further quantitative analysis.

\subsubsection{Summary}

The results of this study give new insights into the effects of GTX on HL-60 cells. GTX affects the cells at a relative low dose of $0.02 \mu \mathrm{g} / \mathrm{ml}$. The effects may predominantly 
be due to covalent modification instead of ROS production. GTX affects the cell cycle by blocking the entry into the S-phase, but only at doses high enough to induce apoptosis.

ICAT labelling led to the identification of three putative cellular targets of GTX: tubulin, glyceraldehyde-3-phosphate dehydrogenase and peptidyl-prolyl cis-trans isomerase. ICAT was therefore apparently capable of detecting cysteine modification in a complex sample but further optimization is needed to improve the detection rate, quantitation and reproducibility.

Suggested further work includes:

- Use of optimized ICAT methods for labelling and workup of cell extracts

- ICAT labelling of unreduced BSA to evaluate the effects compared to reduced BSA

- ICAT labelling of BSA treated with GTX to identify possible reactive cysteines

- Characterization by MS/MS of the possible cysteine modifications of tubulin, glyceraldehyde-3-phosphate dehydrogenase and peptidyl-propyl cis-trans isomerase, either using cell extracts or by exposure of purified proteins to GTX

- Investigation of the potential effects of GTX on destabilization of tubulin in vitro and in cultured cells. 


\section{REFERENCES}

Abad, A., Fernandez-Molina, J. V., Bikandi, J., Ramirez, A., Margareto, J., Sendino, J., Hernando, F. L., Ponton, J., Garaizar, J. and Rementeria, A. (2010). "What makes Aspergillus fumigatus a successful pathogen? Genes and molecules involved in invasive aspergillosis." Revista Iberoamericana De Micologia 27: 155-182.

Antony, M. L., Lee, J., Hahm, E. R., Kim, S. H., Marcus, A. I., Kumari, V., Ji, X., Yang, Z., Vowell, C. L., Wipf, P., Uechi, G. T., Yates, N. A., Romero, G., Sarkar, S. N. and Singh, S. V. (2014). "Growth arrest by the antitumor steroidal lactone withaferin $\mathrm{A}$ in human breast cancer cells is associated with downregulation and covalent binding at cysteine 303 of beta-tubulin." The Journal of biological chemistry 289: $1852-1865$.

Arends, M. J., Morris, R. G. and Wyllie, A. H. (1990). "Apoptosis. The role of the endonuclease." Am J Pathol 136: 593-608.

Artavanis-Tsakonas, S., Rand, M. D. and Lake, R. J. (1999). "Notch signaling: cell fate control and signal integration in development." Science 284: 770-776.

Banas, T., Banas, B. and Wolny, M. (1976). "Kinetic studies of the reactivity of the sulfhydryl groups of glyceraldehyde-3-phosphate dehydrogenase." European Journal of Biochemistry 68: 313-319.

Bernardi, P. (2013). "The mitochondrial permeability transition pore: a mystery solved?" Front Physiol 4: 95.

Bernardo, P. H., Brasch, N., Chai, C. L. and Waring, P. (2003). "A novel redox mechanism for the glutathionedependent reversible uptake of a fungal toxin in cells." The Journal of biological chemistry 278: 46549-46555.

Berridge, M. V., Herst, P. M. and Tan, A. S. (2005). "Tetrazolium dyes as tools in cell biology: new insights into their cellular reduction." Biotechnol Annu Rev 11: 127-152.

Blajeski, A. L., Phan, V. A., Kottke, T. J. and Kaufmann, S. H. (2002). "G1 and G2 cell-cycle arrest following microtubule depolymerization in human breast cancer cells." Journal of Clinical Investigation 110: 9199.

Bok, J. W., Chung, D., Balajee, S. A., Marr, K. A., Andes, D., Nielsen, K. F., Frisvad, J. C., Kirby, K. A. and Keller, N. P. (2006). "Gliz, a transcriptional regulator of gliotoxin biosynthesis, contributes to Aspergillus fumigatus virulence." Infection and Immunity 74: 6761-6768.

Brian, P. W. and Hemming, H. G. (1945). "Gliotoxin, a fungistatic metabolic product of Trichoderma viride." Annals of Applied Biology 32: 214-220.

Cavallito, C. J., Bailey, J. H. and Warner, W. F. (1946). "The Reversible Inactivation of Gliotoxin by Thiols." Journal of the American Chemical Society 68: 715-716.

Chang, S. L., Chiang, Y. M., Yeh, H. H., Wu, T. K. and Wang, C. C. (2013). "Reconstitution of the early steps of gliotoxin biosynthesis in Aspergillus nidulans reveals the role of the monooxygenase GliC." Bioorganic \& medicinal chemistry letters 23: 2155-2157.

Cho, M. L., Moon, Y. M., Heo, Y. J., Woo, Y. J., Ju, J. H., Park, K. S., Kim, S. I., Park, S. H., Kim, H. Y. and Min, J. K. (2009). "NF-kappaB inhibition leads to increased synthesis and secretion of MIF in human CD4+ T cells." Immunology Letters 123: 21-30. 
Cordiner, S. J. and Jordan, T. W. (1983). "Inhibition by sporidesmin of hepatocyte bile acid transport." Biochem J 212: 197-204.

Crompton, M. (1999). "The mitochondrial permeability transition pore and its role in cell death." Biochem J 341 ( Pt 2): 233-249.

Eichner, R. D., Waring, P., Geue, A. M., Braithwaite, A. W. and Mullbacher, A. (1988). "Gliotoxin causes oxidative damage to plasmid and cellular DNA." The Journal of biological chemistry 263: 3772-3777.

Fox, E. M. and Howlett, B. J. (2008). "Biosynthetic gene clusters for epipolythiodioxopiperazines in filamentous fungi." Mycological Research 112: 162-169.

Gallagher, L., Owens, R. A., Dolan, S. K., O'Keeffe, G., Schrettl, M., Kavanagh, K., Jones, G. W. and Doyle, S. (2012). "The Aspergillus fumigatus protein GliK protects against oxidative stress and is essential for gliotoxin biosynthesis." Eukaryot Cell 11: 1226-1238.

Gardiner, D. M., Cozijnsen, A. J., Wilson, L. M., Pedras, M. S. and Howlett, B. J. (2004). "The sirodesmin biosynthetic gene cluster of the plant pathogenic fungus Leptosphaeria maculans." Molecular Microbiology 53: 1307-1318.

Gardiner, D. M. and Howlett, B. J. (2005). "Bioinformatic and expression analysis of the putative gliotoxin biosynthetic gene cluster of Aspergillus fumigatus." FEMS Microbiology Letters 248: 241-248.

Gardiner, D. M., Waring, P. and Howlett, B. J. (2005). "The epipolythiodioxopiperazine (ETP) class of fungal toxins: distribution, mode of action, functions and biosynthesis." Microbiology 151: 1021-1032.

Gygi, S. P., Rist, B., Gerber, S. A., Turecek, F., Gelb, M. H. and Aebersold, R. (1999). "Quantitative analysis of complex protein mixtures using isotope-coded affinity tags." Nature Biotechnology 17: 994-999.

Hansen, K. C., Schmitt-Ulms, G., Chalkley, R. J., Hirsch, J., Baldwin, M. A. and Burlingame, A. L. (2003). "Mass spectrometric analysis of protein mixtures at low levels using cleavable $13 \mathrm{C}$-isotope-coded affinity tag and multidimensional chromatography." Molecular \& Cellular Proteomics 2: 299-314.

Hartland, S. N., Murphy, F., Aucott, R. L., Abergel, A., Zhou, X., Waung, J., Patel, N., Bradshaw, C., Collins, J., Mann, D., Benyon, R. C. and Iredale, J. P. (2009). "Active matrix metalloproteinase-2 promotes apoptosis of hepatic stellate cells via the cleavage of cellular $\mathrm{N}$-cadherin." Liver international : official journal of the International Association for the Study of the Liver 29: 966-978.

Heald, R. and Nogales, E. (2002). "Microtubule dynamics." Journal of Cell Science 115: 3-4.

Henkel, T., Machleidt, T., Alkalay, I., Kronke, M., Ben-Neriah, Y. and Baeuerle, P. A. (1993). "Rapid proteolysis of I kappa B-alpha is necessary for activation of transcription factor NF-kappa B." Nature 365: $182-185$.

Hubmann, R., Hilgarth, M., Schnabl, S., Ponath, E., Reiter, M., Demirtas, D., Sieghart, W., Valent, P., Zielinski, C., Jager, U. and Shehata, M. (2013). "Gliotoxin is a potent NOTCH2 transactivation inhibitor and efficiently induces apoptosis in chronic lymphocytic leukaemia (CLL) cells." British Journal of Haematology 160: 618-629.

Hur, J. M., Yun, H. J., Yang, S. H., Lee, W. Y., Joe, M. H. and Kim, D. (2008). "Gliotoxin enhances radiotherapy via inhibition of radiation-induced GADD45a, p38, and NF kappa B activation." Journal of Cellular Biochemistry 104: 2174-2184.

Hurne, A. M., Chai, C. L. L. and Waring, P. (2000). "Inactivation of rabbit muscle creatine kinase by reversible formation of an internal disulfide bond induced by the fungal toxin gliotoxin." Journal of Biological Chemistry 275: 25202-25206. 
Jordan, T. W. and Cordiner, S. J. (1987). "Fungal epipolythiodioxopiperazine toxins have therapeutic potential and roles in disease." Trends in Pharmacological Sciences 8: 144-149.

Jordan, T. W. and Pedersen, J. S. (1986). "Sporidesmin and gliotoxin induce cell detachment and perturb microfilament structure in cultured liver cells." Journal of Cell Science 85: 33-46.

Kim, Y. J., Pannell, L. K. and Sackett, D. L. (2004). "Mass spectrometric measurement of differential reactivity of cysteine to localize protein-ligand binding sites. Application to tubulin-binding drugs." Analytical Biochemistry 332: 376-383.

Kondo, Y., Shen, L., Ahmed, S., Boumber, Y., Sekido, Y., Haddad, B. R. and Issa, J. P. (2008). "Downregulation of histone $\mathrm{H}_{3}$ lysine 9 methyltransferase $\mathrm{G} 9 \mathrm{a}$ induces centrosome disruption and chromosome instability in cancer cells." PLoS One 3: e2037.

Kozarova, A., Sliskovic, I., Mutus, B., Simon, E. S., Andrews, P. C. and Vacratsis, P. O. (2007). "Identification of redox sensitive thiols of protein disulfide isomerase using isotope coded affinity technology and mass spectrometry." Journal of the American Society for Mass Spectrometry 18: 260-269.

Kroll, M., Arenzana-Seisdedos, F., Bachelerie, F., Thomas, D., Friguet, B. and Conconi, M. (1999). "The secondary fungal metabolite gliotoxin targets proteolytic activities of the proteasome." Chemistry \& Biology 6: 689-698.

Kweon, Y. O., Paik, Y. H., Schnabl, B., Qian, T., Lemasters, J. J. and Brenner, D. A. (2003). "Gliotoxinmediated apoptosis of activated human hepatic stellate cells." Journal of Hepatology 39: 38-46.

Kwon-Chung, K. J. and Sugui, J. A. (2009). "What do we know about the role of gliotoxin in the pathobiology of Aspergillus fumigatus?" Med Mycol 47 Suppl 1: S97-103.

Lane, K. T. and Beese, L. S. (2006). "Thematic review series: lipid posttranslational modifications. Structural biology of protein farnesyltransferase and geranylgeranyltransferase type I." Journal of Lipid Research 47: 681-699.

Li, H., Kolluri, S. K., Gu, J., Dawson, M. I., Cao, X., Hobbs, P. D., Lin, B., Chen, G., Lu, J., Lin, F., Xie, Z., Fontana, J. A., Reed, J. C. and Zhang, X. (2000). "Cytochrome c release and apoptosis induced by mitochondrial targeting of nuclear orphan receptor TR3." Science 289: 1159-1164.

Liu, J., Albers, M. W., Chen, C. M., Schreiber, S. L. and Walsh, C. T. (1990). "Cloning, expression, and purification of human cyclophilin in Escherichia coli and assessment of the catalytic role of cysteines by site-directed mutagenesis." Proceedings of the National Academy of Sciences of the United States of America 87: 2304-2308.

Luduena, R. F. and Roach, M. C. (1991). "Tubulin sulfhydryl groups as probes and targets for antimitotic and antimicrotubule agents." Pharmacology \& Therapeutics 49: 133-152.

Miele, L. (2006). "Notch signaling." Clinical cancer research : an official journal of the American Association for Cancer Research 12: 1074-1079.

Miquel, K., Pradines, A., Sun, J., Qian, Y., Hamilton, A. D., Sebti, S. M. and Favre, G. (1997). "GGTI-298 induces Go-G1 block and apoptosis whereas FTI-277 causes G2-M enrichment in A549 cells." Cancer Research 57: 1846-1850.

Mosmann, T. (1983). "Rapid colorimetric assay for cellular growth and survival: application to proliferation and cytotoxicity assays." Journal of Immunological Methods 65: 55-63. 
Mullbacher, A., Moreland, A. F., Waring, P., Sjaarda, A. and Eichner, R. D. (1988). "Prevention of graftversus-host disease by treatment of bone marrow with gliotoxin in fully allogeneic chimeras and their cytotoxic T cell repertoire." Transplantation 46: 120-125.

Munday, R. (1982). "Studies on the mechanism of toxicity of the mycotoxin, sporidesmin. I. Generation of superoxide radical by sporidesmin." Chemico-Biological Interactions 41: 361-374.

Myhre, O., Andersen, J. M., Aarnes, H. and Fonnum, F. (2003). "Evaluation of the probes 2',7'dichlorofluorescin diacetate, luminol, and lucigenin as indicators of reactive species formation." Biochemical Pharmacology 65: 1575-1582.

Napetschnig, J. and Wu, H. (2013). "Molecular basis of NF-kappaB signaling." Annual review of biophysics 42: 443-468.

Niederhut, M. S., Gibbons, B. J., Perez-Miller, S. and Hurley, T. D. (2001). "Three-dimensional structures of the three human class I alcohol dehydrogenases." Protein Science 10: 697-706.

Okamoto, M., Yoshida, K., Uchida, I., Nishikawa, M., Kohsaka, M. and Aoki, H. (1986). "Studies of PlateletActivating-Factor (Paf) Antagonists from Microbial Products .1. Bisdethiobis(Methylthio)Gliotoxin and Its Derivatives." Chemical \& Pharmaceutical Bulletin 34: 340-344.

Pace, N. J. and Weerapana, E. (2013). "Diverse functional roles of reactive cysteines." ACS Chem Biol 8: 283296.

Pahl, H. L., Krauss, B., Schulze-Osthoff, K., Decker, T., Traenckner, E. B., Vogt, M., Myers, C., Parks, T., Warring, P., Muhlbacher, A., Czernilofsky, A. P. and Baeuerle, P. A. (1996a). "The immunosuppressive fungal metabolite gliotoxin specifically inhibits transcription factor NF-kappaB." J Exp Med 183: 18291840.

Pahl, H. L., Krauss, B., SchulzeOsthoff, K., Decker, T., Traenckner, E. B. M., Vogt, M., Myers, C., Parks, T., Warring, P., Muhlbacher, A., Czernilofsky, A. P. and Baeuerle, P. A. (1996b). "The immunosuppressive fungal metabolite gliotoxin specifically inhibits transcription factor NF-kappa B." Journal of Experimental Medicine 183: 1829-1840.

Perham, R. N. (1969). "The comparative structure of mammalian glyceraldehyde 3-phosphate dehydrogenases." Biochem J 111: 17-21.

Perkins, D. N., Pappin, D. J. C., Creasy, D. M. and Cottrell, J. S. (1999). "Probability-based protein identification by searching sequence databases using mass spectrometry data." Electrophoresis 20: 3551-3567.

Peterson, D. E., Collier, J. M., Katterman, M. E., Turner, R. A. and Riley, M. R. (2010). "Cytotoxicity of bacterial-derived toxins to immortal lung epithelial and macrophage cells." Applied Biochemistry and Biotechnology 160: 751-763.

Rashmi, R., Schnulle, P. M., Maddox, A. C., Armbrecht, E. S. and Koenig, J. M. (2011). "Flice inhibitory protein is associated with the survival of neonatal neutrophils." Pediatric Research 70: 327-331.

Resnitzky, D. and Reed, S. I. (1995). "Different roles for cyclins D1 and E in regulation of the G1-to-S transition." Molecular and Cellular Biology 15: 3463-3469.

Scharf, D. H., Remme, N., Habel, A., Chankhamjon, P., Scherlach, K., Heinekamp, T., Hortschansky, P., Brakhage, A. A. and Hertweck, C. (2011). "A dedicated glutathione S-transferase mediates carbonsulfur bond formation in gliotoxin biosynthesis." Journal of the American Chemical Society 133: 12322-12325. 
Scharf, D. H., Remme, N., Heinekamp, T., Hortschansky, P., Brakhage, A. A. and Hertweck, C. (2010). "Transannular disulfide formation in gliotoxin biosynthesis and its role in self-resistance of the human pathogen Aspergillus fumigatus." Journal of the American Chemical Society 132: 10136-10141.

Schrettl, M., Carberry, S., Kavanagh, K., Haas, H., Jones, G. W., O'Brien, J., Nolan, A., Stephens, J., Fenelon, O. and Doyle, S. (2010). "Self-Protection against Gliotoxin-A Component of the Gliotoxin Biosynthetic Cluster, GliT, Completely Protects Aspergillus fumigatus Against Exogenous Cliotoxin." PLoS Pathogens 6.

Schweizer, M. and Richter, C. (1994). "Gliotoxin Stimulates Ca2+ Release from Intact Rat Liver Mitochondria." Biochemistry 33: 13401-13405.

Sethuraman, M., Clavreul, N., Huang, H., McComb, M. E., Costello, C. E. and Cohen, R. A. (2007). "Quantification of oxidative posttranslational modifications of cysteine thiols of p21ras associated with redox modulation of activity using isotope-coded affinity tags and mass spectrometry." Free Radic Biol Med 42: 823-829.

Sethuraman, M., McComb, M. E., Huang, H., Huang, S., Heibeck, T., Costello, C. E. and Cohen, R. A. (2004). "Isotope-coded affinity tag (ICAT) approach to redox proteomics: identification and quantitation of oxidant-sensitive cysteine thiols in complex protein mixtures." J Proteome Res 3: 1228-1233.

Shen, K., Chang, W., Gao, X., Wang, H., Niu, W., Song, L. and Qin, X. (2011). "Depletion of activated hepatic stellate cell correlates with severe liver damage and abnormal liver regeneration in acetaminopheninduced liver injury." Acta Biochim Biophys Sin (Shanghai) 43: 307-315.

Silva, J. P., Winterhalter, K. H. and Richter, C. (1997). "t-Butylhydroperoxide and gliotoxin stimulate Ca2+ release from rat skeletal muscle mitochondria." Redox report : communications in free radical research 3: 331-341.

Speth, C., Kupfahl, C., Pfaller, K., Hagleitner, M., Deutinger, M., Wurzner, R., Mohsenipour, I., Lass-Florl, C. and Rambach, G. (2011). "Gliotoxin as putative virulence factor and immunotherapeutic target in a cell culture model of cerebral aspergillosis." Molecular Immunology 48: 2122-2129.

Srinivasan, U., Bala, A., Jao, S. C., Starke, D. W., Jordan, T. W. and Mieyal, J. J. (2006). "Selective inactivation of glutaredoxin by sporidesmin and other epidithiopiperazinediones." Biochemistry 45: 8978-8987.

Suen, Y. K., Fung, K. P., Lee, C. Y. and Kong, S. K. (2001). "Cliotoxin induces apoptosis in cultured macrophages via production of reactive oxygen species and cytochrome $\mathrm{c}$ release without mitochondrial depolarization." Free Radical Research Communications 35: 1-10.

Sugui, J. A., Pardo, J., Chang, Y. C., Zarember, K. A., Nardone, G., Galvez, E. M., Muellbacher, A., Gallin, J. I., Simon, M. M. and Kwon-Chung, K. J. (2007). "Gliotoxin is a virulence factor of Aspergillus fumigatus: glip deletion attenuates virulence in mice Immunosuppressed with hydrocortisone." Eukaryotic Cell 6: 1562-1569.

Suhadolnik, R. J. and Chenoweth, R. G. (1958). "Biosynthesis of Gliotoxin .1. Incorporation of Phenylalanine1-C-14 and Phenylalanine-2-C-14." Journal of the American Chemical Society 80: 4391-4392.

Sun, Y., Takada, K., Takemoto, Y., Yoshida, M., Nogi, Y., Okada, S. and Matsunaga, S. (2012). "Gliotoxin analogues from a marine-derived fungus, Penicillium sp., and their cytotoxic and histone methyltransferase inhibitory activities." Journal of Natural Products 75: 111-114.

Tartakovsky, B., Sredni, B., Zigman-Hoffman, E., Senyor, G. and Naparstek, E. (2012). "A Peptide of CD14 Protects Human Lymphocytes from Gliotoxin-Induced Apoptosis." International Journal of Peptide Research and Therapeutics 18: 249-258. 
Thomas, C., Carr, A. C. and Winterbourn, C. C. (1994). "Free radical inactivation of rabbit muscle creatinine kinase: catalysis by physiological and hydrolyzed ICRF-187 (ICRF-198) iron chelates." Free Radical Research 21: 387-397.

Traenckner, E. B., Wilk, S. and Baeuerle, P. A. (1994). "A proteasome inhibitor prevents activation of NFkappa B and stabilizes a newly phosphorylated form of I kappa B-alpha that is still bound to NFkappa B." The EMBO journal 13: 5433-5441.

Trebec-Reynolds, D. P., Voronov, I., Heersche, J. N. and Manolson, M. F. (2010). "VEGF-A expression in osteoclasts is regulated by NF-kappaB induction of HIF-1alpha." Journal of Cellular Biochemistry 110: 343-351.

Vanderpyl, D., Inokoshi, J., Shiomi, K., Yang, H., Takeshima, H. and Omura, S. (1992). "Inhibition of FarnesylProtein Transferase by Gliotoxin and Acetylgliotoxin." Journal of Antibiotics 45: 1802-1805.

Vigushin, D. M., Mirsaidi, N., Brooke, G., Sun, C., Pace, P., Inman, L., Moody, C. J. and Coombes, R. C. (2004). "Gliotoxin is a dual inhibitor of farnesyltransferase and geranylgeranyltransferase I with antitumor activity against breast cancer in vivo." Medical Oncology 21: 21-30.

Wang, H. and Joseph, J. A. (1999). "Quantifying cellular oxidative stress by dichlorofluorescein assay using microplate reader." Free Radic Biol Med 27: 612-616.

Waring, P. (1997). "Apoptosis Induced by Gliotoxin Is Preceded by Phosphorylation of Histone H3 and Enhanced Sensitivity of Chromatin to Nuclease Digestion." Journal of Biological Chemistry 272: 17929-17936.

Waring, P. and Beaver, J. (1996). "Gliotoxin and related epipolythiodioxopiperazines." General Pharmacology 27: 1311-1316.

Waring, P., Sjaarda, A. and Lin, Q. H. (1995). "Gliotoxin Inactivates Alcohol-Dehydrogenase by Either Covalent Modification or Free-Radical Damage Mediated by Redox Cycling." Biochemical Pharmacology 49: 1195-1201.

Weindling, R. and Emerson, O. H. (1936). "The isolation of a toxic substance from the culture filtrate of Trichoderma." Phytopathology 26.

Wilkinson, S. and Spilsbury, J. F. (1965). "Gliotoxin from Aspergillus chevalieri (Mangin) Thom et Church." Nature 206: 619.

Witko-Sarsat, V., Mocek, J., Bouayad, D., Tamassia, N., Ribeil, J. A., Candalh, C., Davezac, N., Reuter, N., Mouthon, L., Hermine, O., Pederzoli-Ribeil, M. and Cassatella, M. A. (2010). "Proliferating cell nuclear antigen acts as a cytoplasmic platform controlling human neutrophil survival." The Journal of experimental medicine 207: 2631-2645.

Woo, R. A. and Poon, R. Y. (2003). "Cyclin-dependent kinases and S phase control in mammalian cells." Cell Cycle 2: 316-324.

Wright, M. C., Issa, R., Smart, D. E., Trim, N., Murray, G. I., Primrose, J. N., Arthur, M. J., Iredale, J. P. and Mann, D. A. (2001). "Gliotoxin stimulates the apoptosis of human and rat hepatic stellate cells and enhances the resolution of liver fibrosis in rats." Gastroenterology 121: 685-698.

Yamada, A., Kataoka, T. and Nagai, K. (2000). "The fungal metabolite gliotoxin: immunosuppressive activity on CTL-mediated cytotoxicity." Immunology Letters 71: 27-32. 
Yoshida, L. S., Abe, S. and Tsunawaki, S. (2000). "Fungal gliotoxin targets the onset of superoxidegenerating NADPH oxidase of human neutrophils." Biochemical and Biophysical Research Communications 268: 716-723.

Zhou, X., Zhao, A., Goping, G. and Hirszel, P. (2000). "Gliotoxin-induced cytotoxicity proceeds via apoptosis and is mediated by caspases and reactive oxygen species in LLC-PK1 cells." Toxicol Sci 54: 194-202. 


\section{APPENDICES}

\section{Appendix A}

Flow table of RP-LC from BSA samples and Experiment 1.

\begin{tabular}{rrr}
\hline Time (min) & $\%$ A & $\%$ B \\
\hline 0 & 98 & 2 \\
40 & 20 & 80 \\
44 & 20 & 80 \\
48 & 98 & 2 \\
56 & 98 & 2 \\
\hline
\end{tabular}

Flow table of RP-LC from Experiment $2 \mathrm{a}$ and $2 \mathrm{~b}$.

\begin{tabular}{|c|c|c|}
\hline Time (min) & $\% A$ & $\%$ B \\
\hline 0 & 98 & 2 \\
\hline 5 & 80 & 20 \\
\hline 35 & 50 & 50 \\
\hline 40 & 20 & 80 \\
\hline 44 & 20 & 80 \\
\hline 48 & 98 & 2 \\
\hline 56 & 98 & 2 \\
\hline
\end{tabular}




\section{Appendix B}

List of reference masses for internal MS calibration.

\begin{aligned} & \hline $\mathbf{m} / \mathbf{z}$ monoisotopic Description \\ & \hline 757.4 Bradykinin fragment 1-7 \\ & 1046.542 Angiotensin Il (human) \\ & 1533.858 P14R (synthetic peptide) \\ & $\begin{array}{l}\text { ACTH fragment 18-39 } \\ \text { (human) }\end{array} \\ & \begin{array}{l}\text { Insulin oxidized B chain } \\ \text { (bovine) }\end{array} \\ &$\hline\end{aligned}

List of reference masses for internal MS/MS calibration.

\begin{tabular}{rl}
\hline $\mathbf{m} / \mathbf{z}$ monoisotopic & Description \\
\hline 157.109 & $\mathrm{~b} 1$ \\
254.162 & $\mathrm{~b} 2$ \\
353.23 & $\mathrm{~b} 3$ \\
481.325 & $\mathrm{~b} 4$ \\
580.393 & $\mathrm{~b} 5$ \\
743.457 & $\mathrm{~b} 6$ \\
840.51 & $\mathrm{~b} 7$ \\
954.552 & $\mathrm{~b} 8$ \\
1011.574 & $\mathrm{~b} 9$ \\
1082.611 & $\mathrm{~b} 10$ \\
1211.654 & $\mathrm{~b} 11$ \\
1326.681 & $\mathrm{~b} 12$ \\
1542.755 & $\mathrm{~b} 14$ \\
1613.792 & $\mathrm{~b} 15$ \\
1742.835 & $\mathrm{~b} 16$ \\
1813.872 & $\mathrm{~b} 17$ \\
1960.94 & $\mathrm{~b} 18$ \\
2057.993 & $\mathrm{~b} 19$ \\
2112.977 & $\mathrm{y} 19$ \\
2171.077 & $\mathrm{~b} 20$ \\
2212.045 & $\mathrm{y} 20$ \\
2300.12 & $\mathrm{~b} 21$ \\
2309.098 & $\mathrm{y} 21$ \\
2447.188 & $\mathrm{~b} 22$ \\
2465.199 & $\mathrm{y} 22$ \\
\hline &
\end{tabular}




\section{Appendix C}

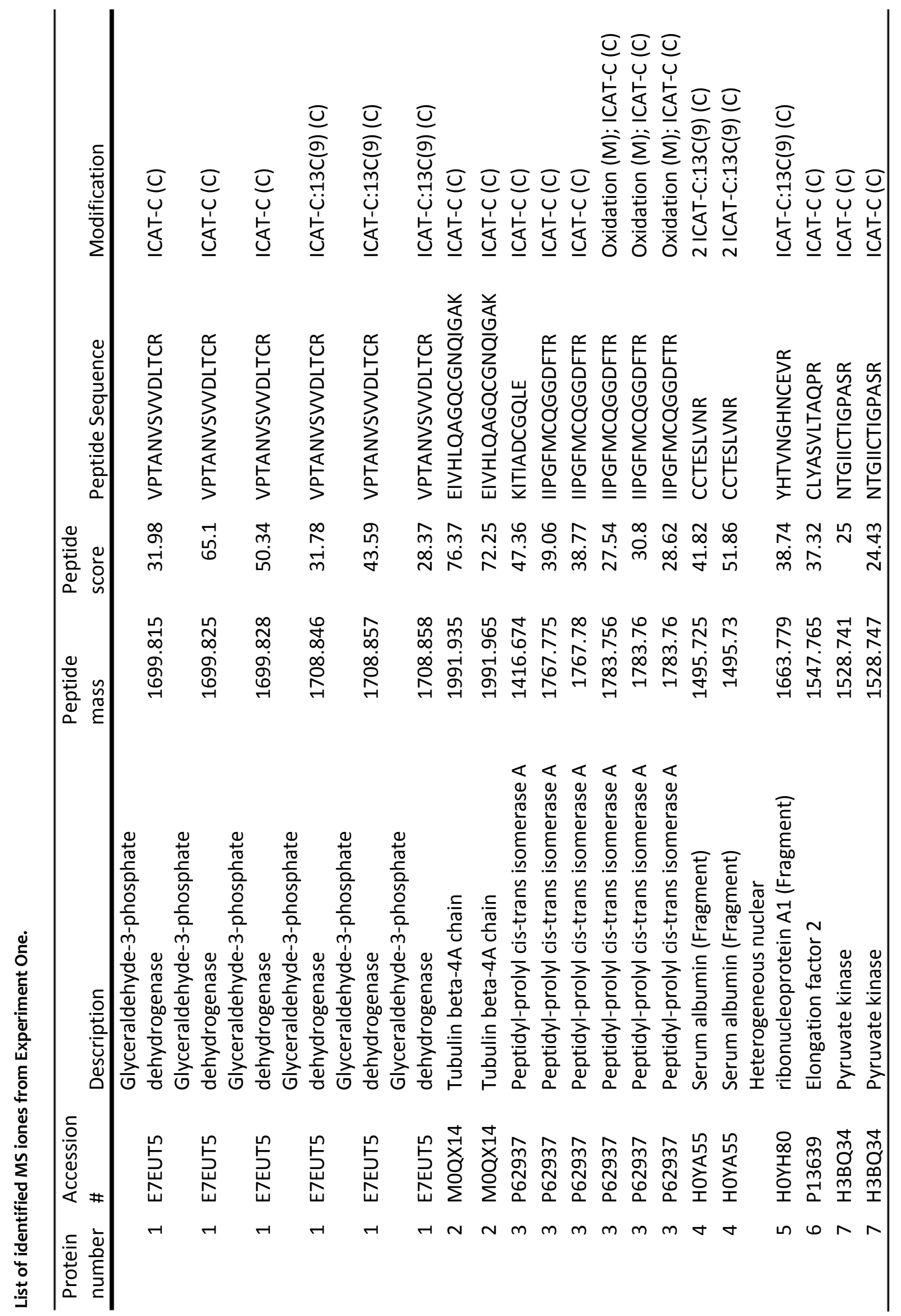




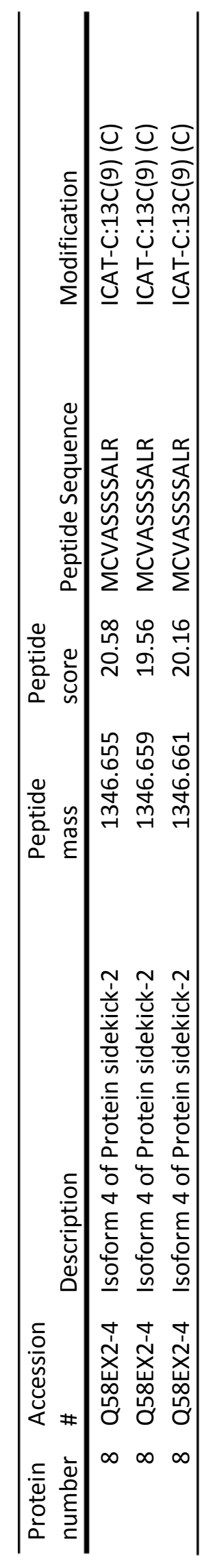




\section{Appendix D}

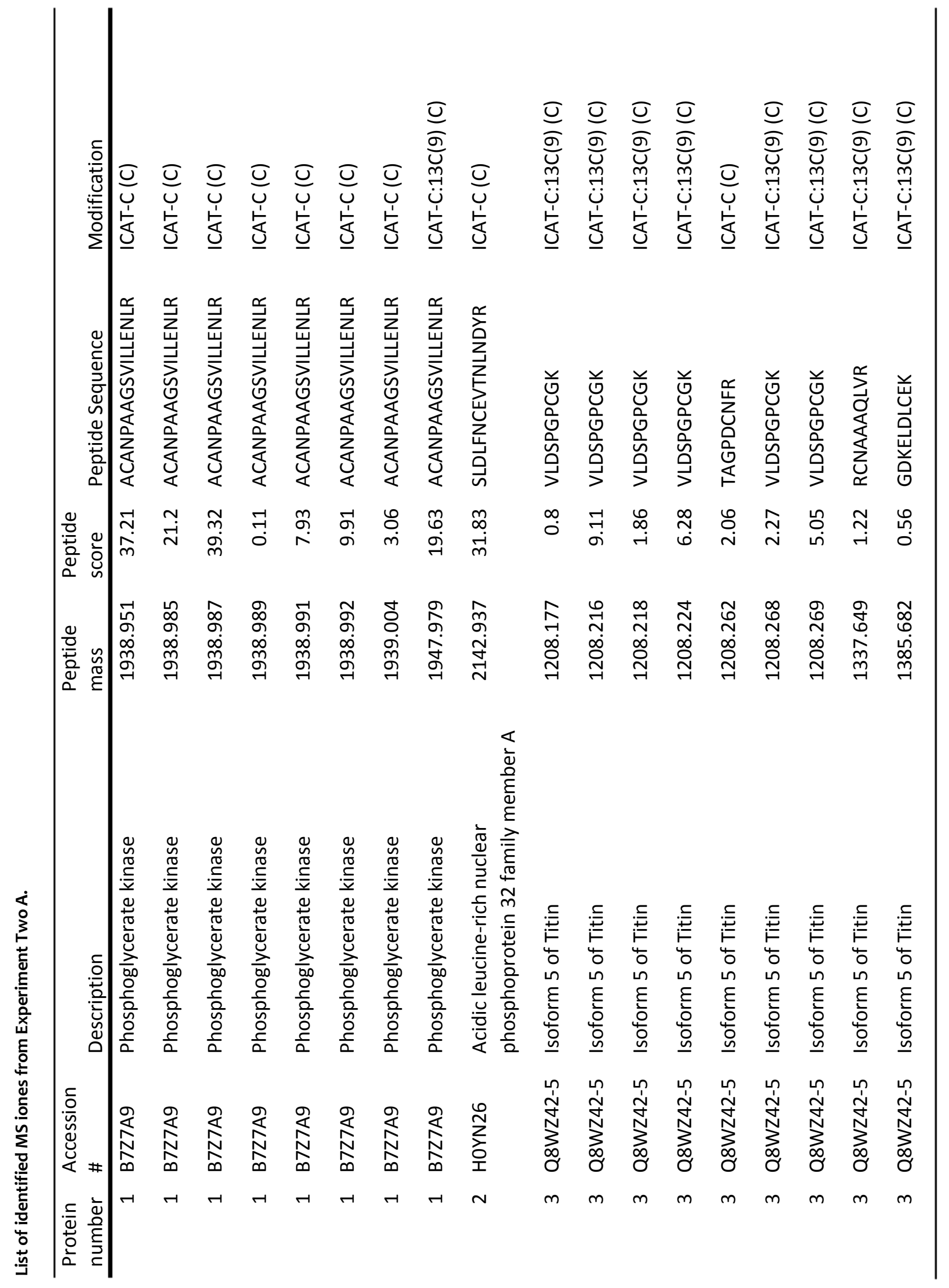




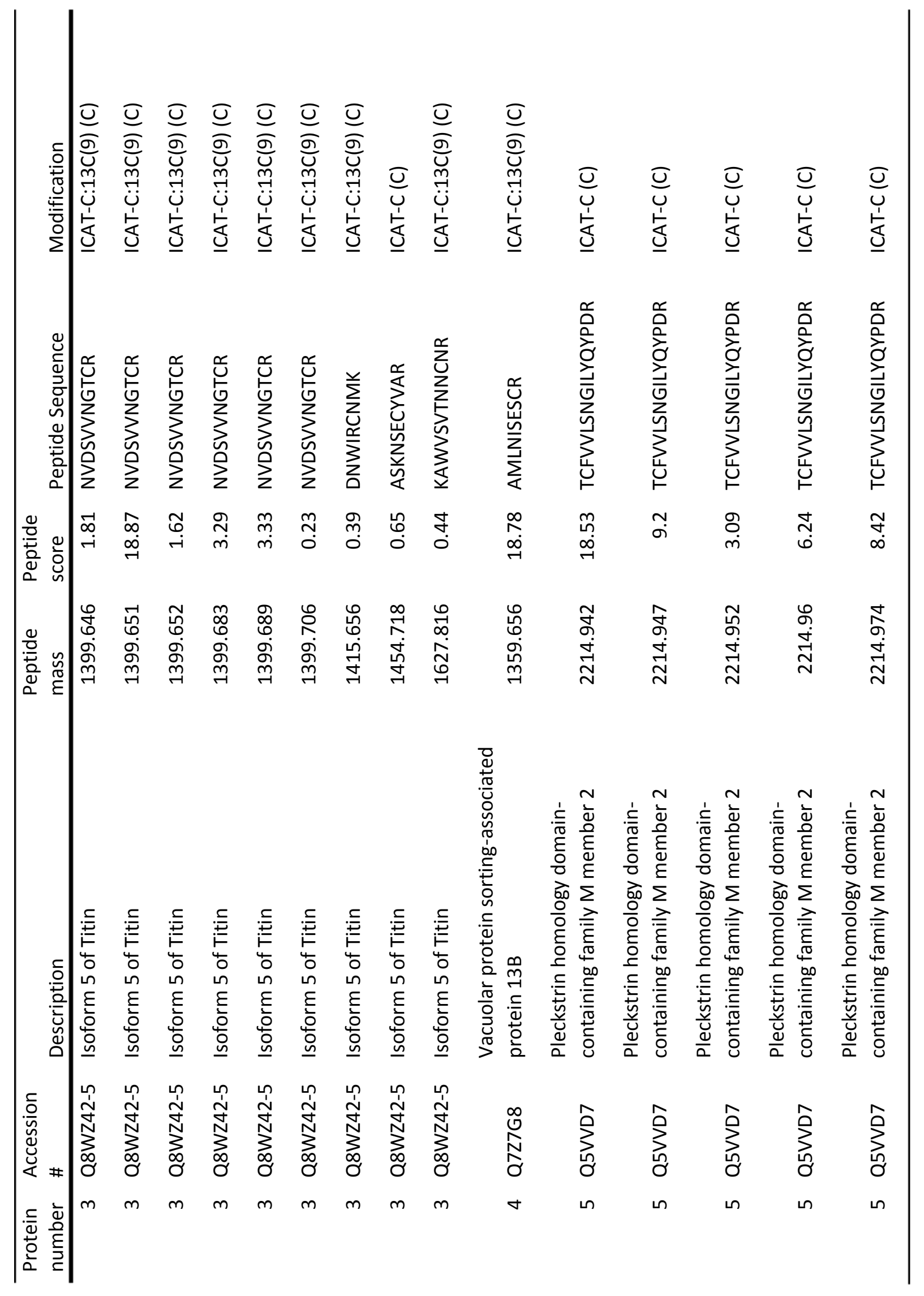




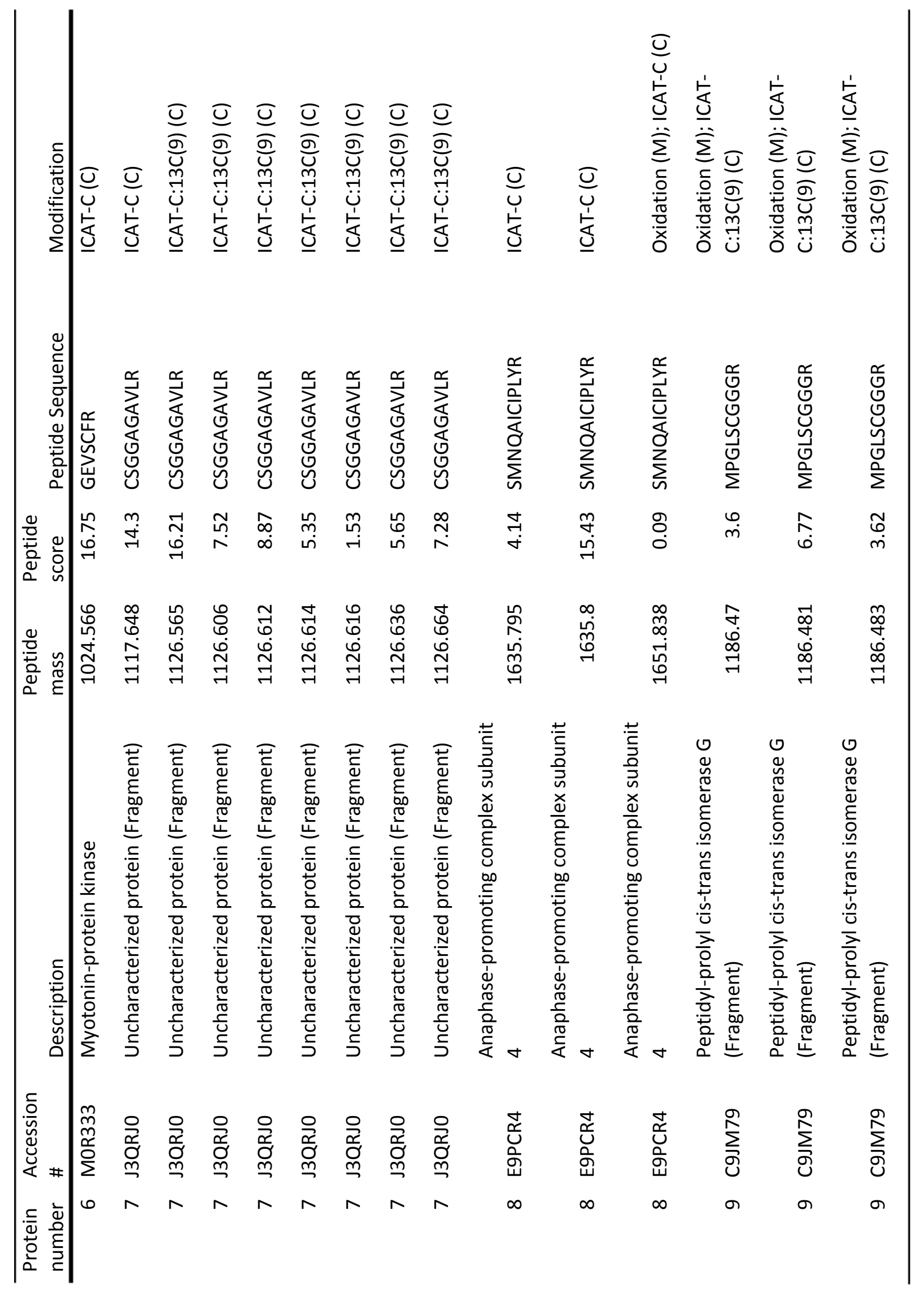




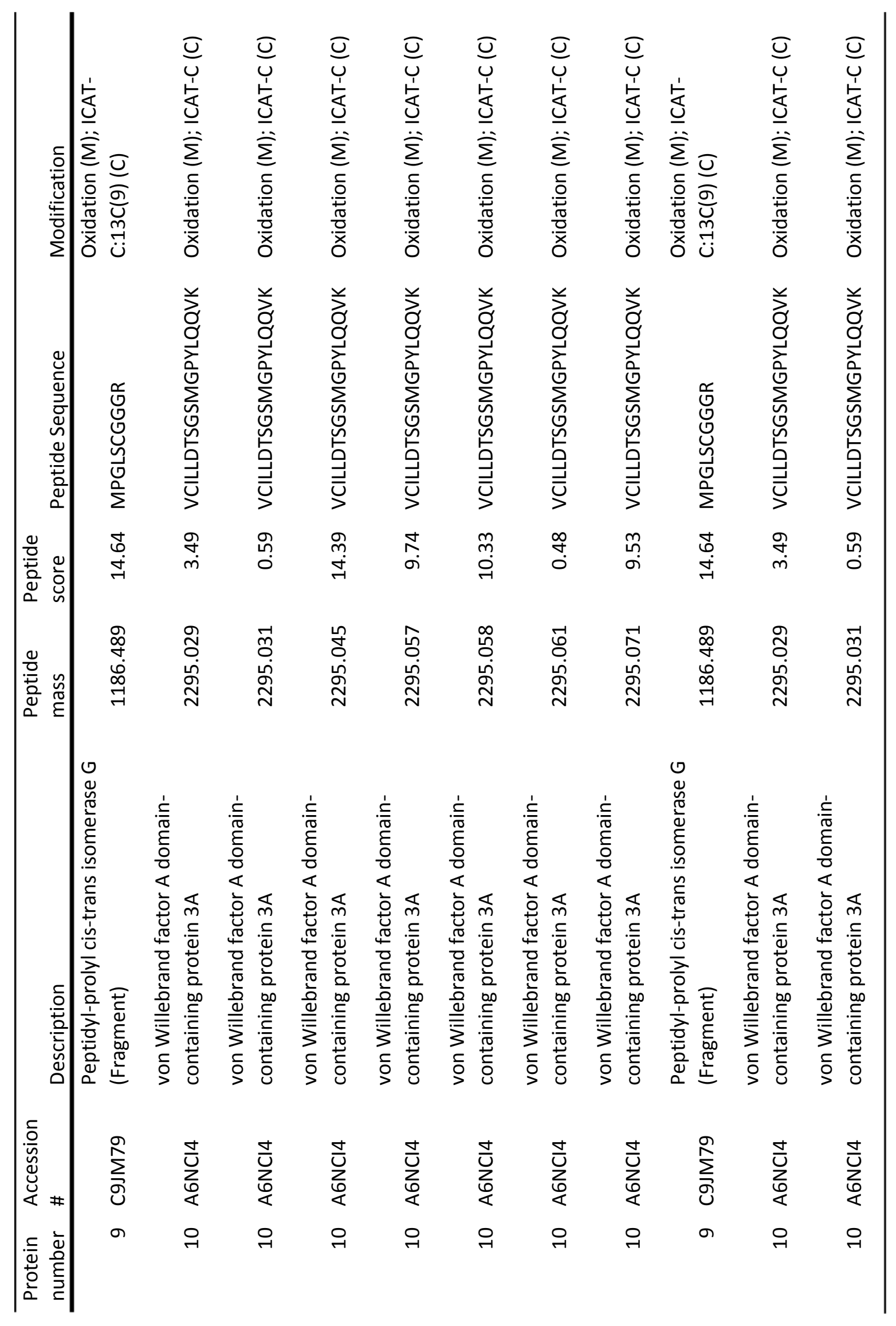




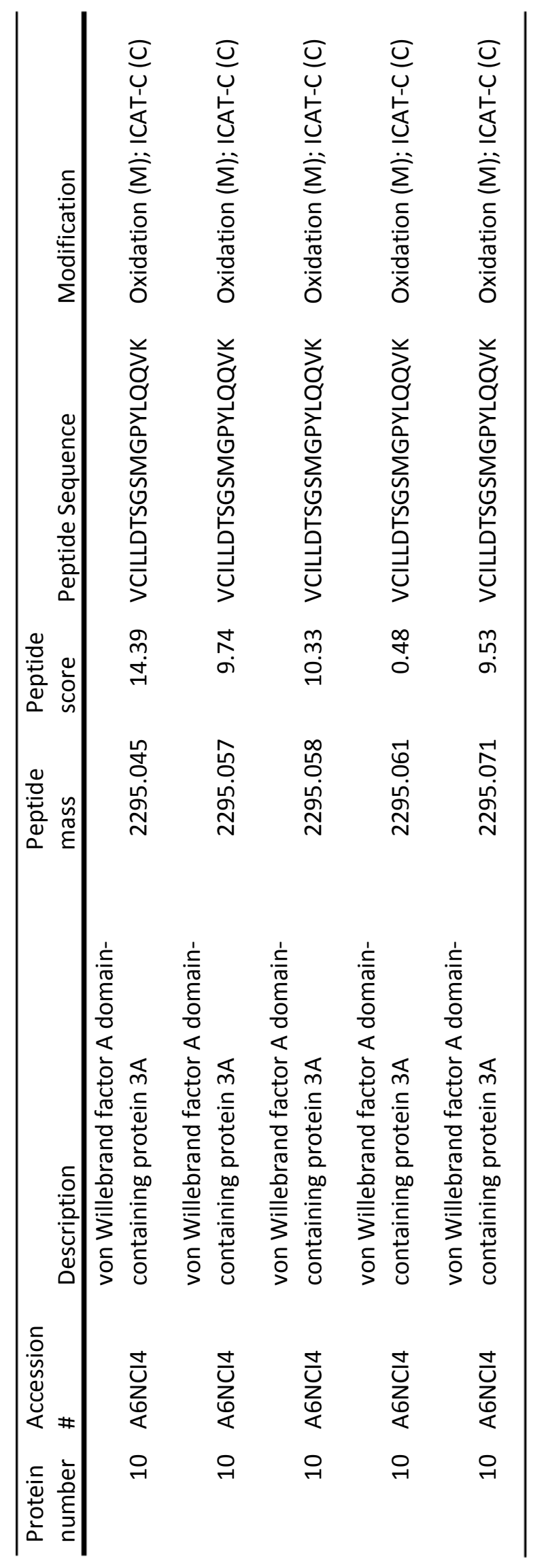




\section{Appendix E}

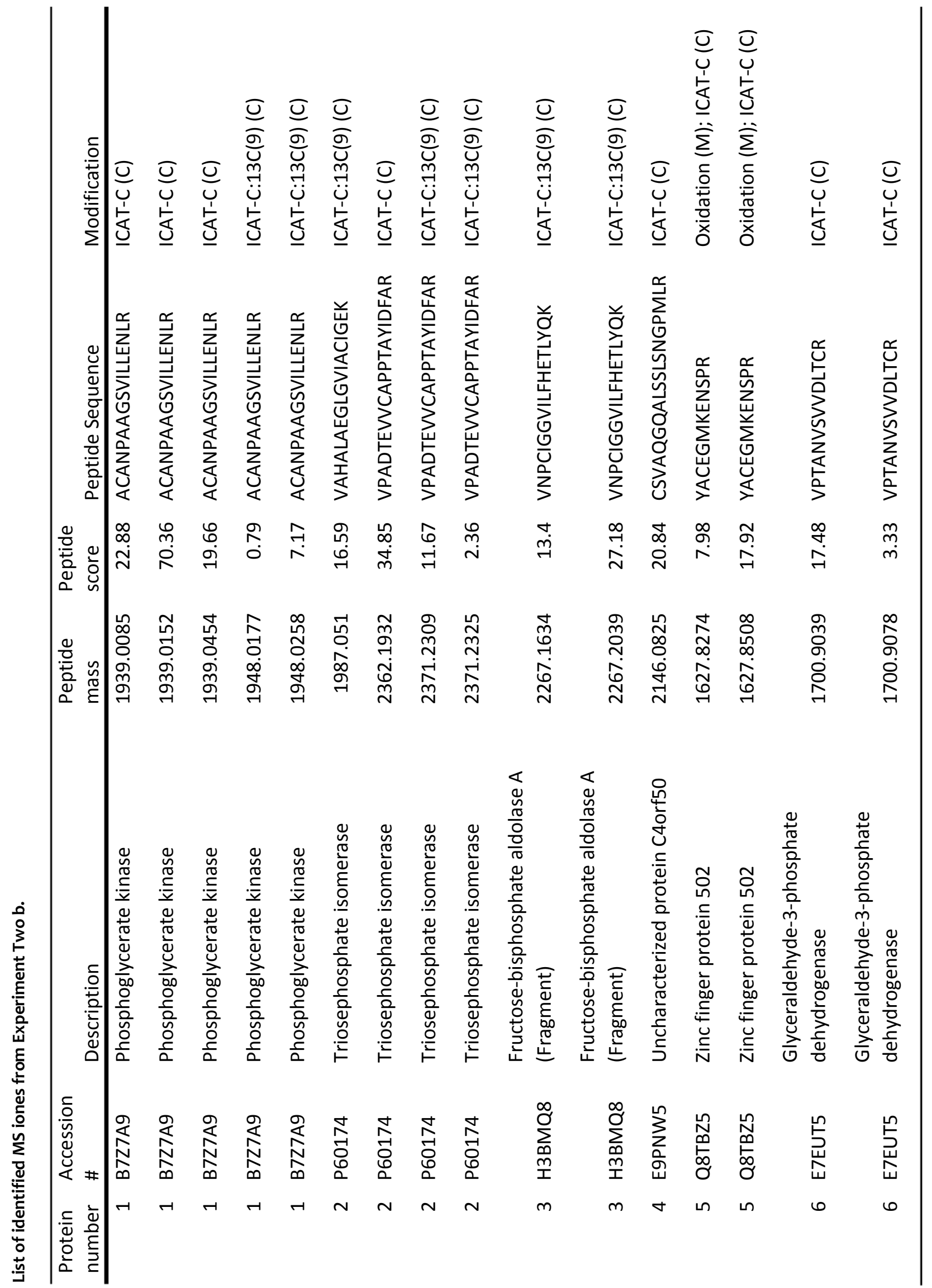




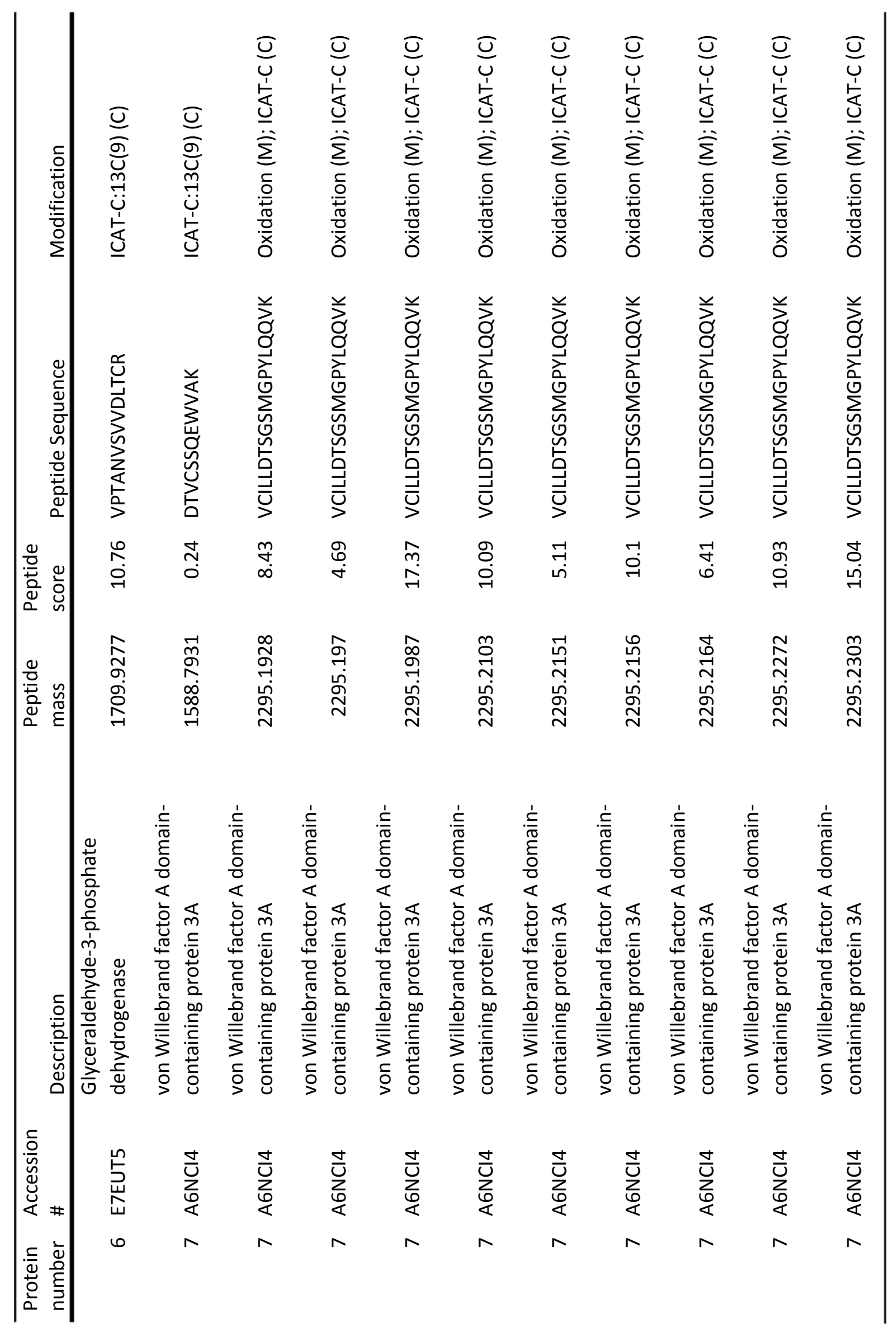




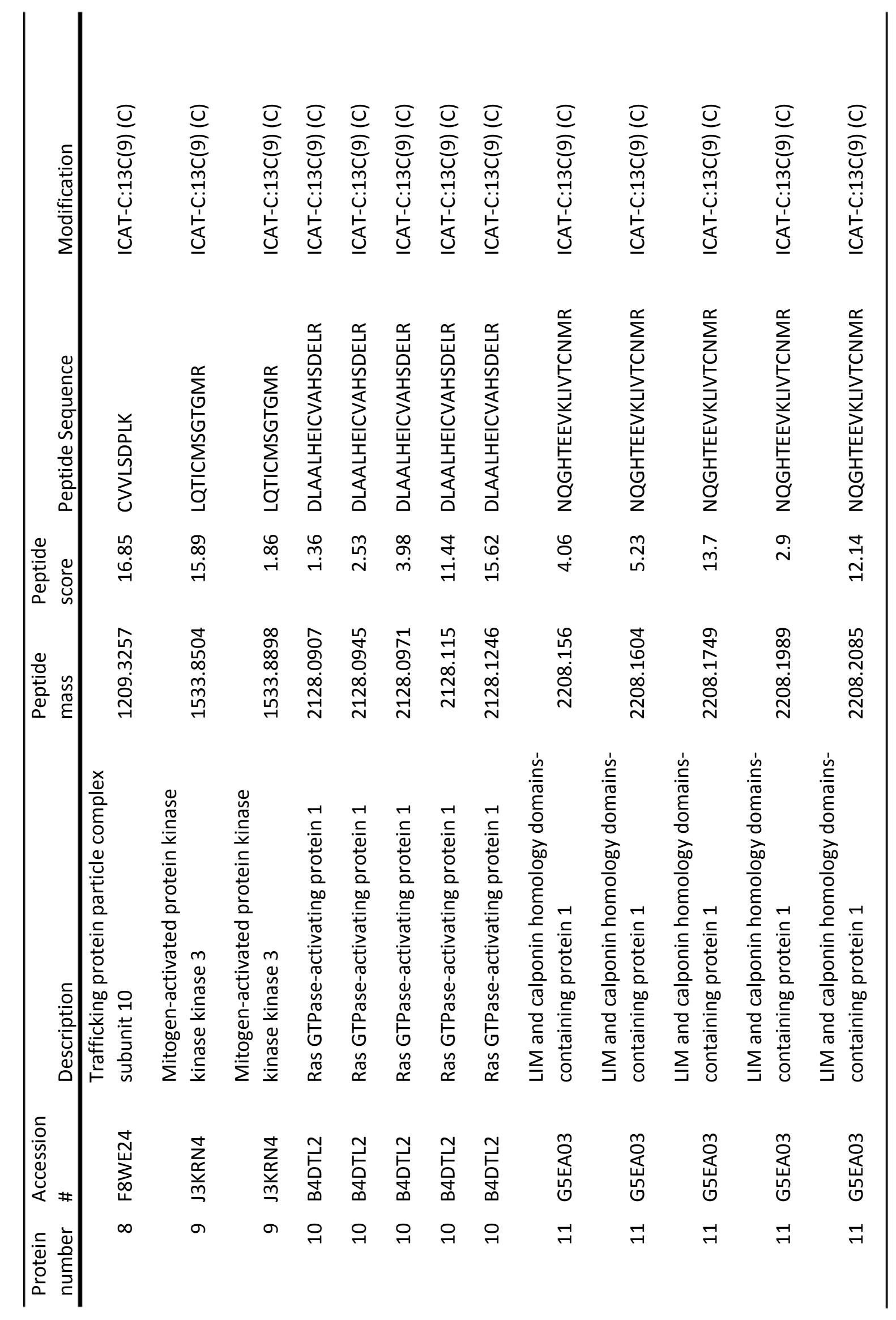




\begin{tabular}{|c|c|c|c|c|}
\hline 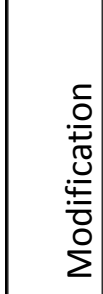 & 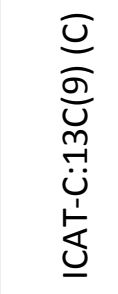 & 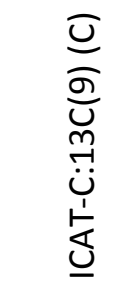 & 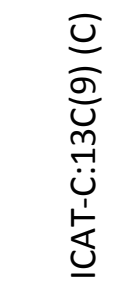 & 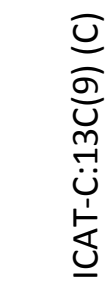 \\
\hline 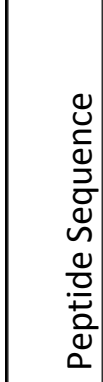 & 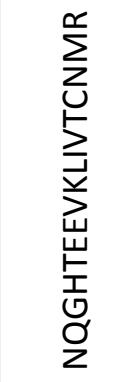 & 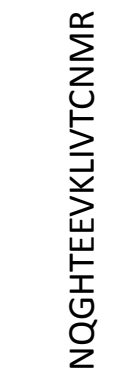 & 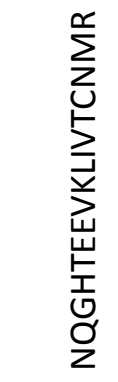 & 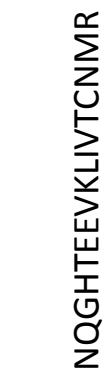 \\
\hline$\frac{0}{0} \frac{0}{\frac{0}{2}}$ & $\begin{array}{l}\infty \\
\infty \\
\emptyset\end{array}$ & $\stackrel{\overbrace{}}{\sigma}$ & $\underset{\infty}{\underset{\infty}{N}}$ & 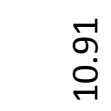 \\
\hline 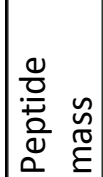 & 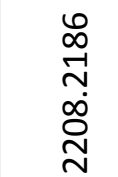 & $\begin{array}{l}\stackrel{n}{Z} \\
\underset{N}{\infty} \\
\stackrel{N}{N}\end{array}$ & 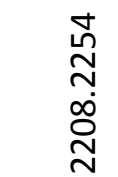 & $\begin{array}{l}\infty \\
\stackrel{0}{N} \\
\infty \\
\stackrel{\infty}{0}\end{array}$ \\
\hline 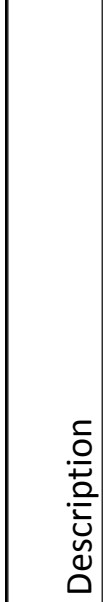 & 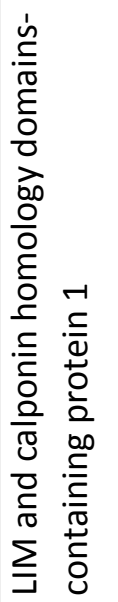 & 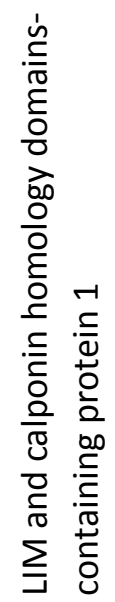 & 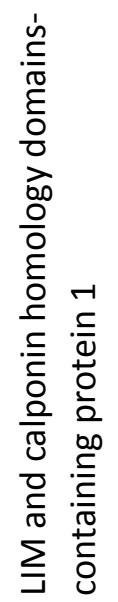 & 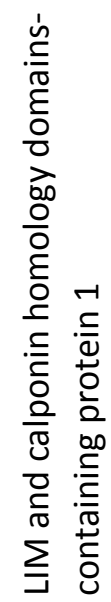 \\
\hline $\begin{array}{l}\frac{\overline{0}}{\tilde{y}} \\
\stackrel{d}{u} \\
\stackrel{u}{<} \#\end{array}$ & 愛 & 鹳 & 总 & 总 \\
\hline 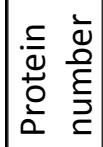 & $\stackrel{-}{-}$ & 각 & $\stackrel{ન}{\digamma}$ & $\vec{\sigma}$ \\
\hline
\end{tabular}

